\title{
A Translation and Study of Chán Master Jìngxiū's 淨修禪師 Preface to the Zǔtáng jí 祖堂集
}

\author{
Laurent Van Cutsem * $*$ and Christoph Anderl (D)
}

check for updates

Citation: Van Cutsem, Laurent, and Christoph Anderl. 2021. A Translation and Study of Chán Master Jingxiū's 淨修禪師 Preface to the Zǔtáng jí 祖堂集. Religions 12: 974. https://doi.org/10.3390/rel12110974

Academic Editor: Daniel M. Stuart

Received: 28 September 2021

Accepted: 27 October 2021

Published: 8 November 2021

Publisher's Note: MDPI stays neutral with regard to jurisdictional claims in published maps and institutional affiliations.

Copyright: (C) 2021 by the authors Licensee MDPI, Basel, Switzerland. This article is an open access article distributed under the terms and conditions of the Creative Commons Attribution (CC BY) license (https:// creativecommons.org/licenses/by/ $4.0 /)$.
Department of Languages and Cultures, Ghent University, 9000 Ghent, Belgium; christoph.anderl@ugent.be * Correspondence: laurent.d.vancutsem@gmail.com

\begin{abstract}
This paper examines Chán master Jìngxiū's preface to the original Zǔtáng jí in one scroll, which was presented to him by Jìng and Yún at the Zhāoqìng monastery in Quánzhōu around the mid-tenth century. Building on a recent TEI-based edition, it offers an annotated translation and comprehensive analysis of the preface, with special attention to its structure, linguistic features, and issues of intertextuality. The essay focuses on elements of textual history, the possible incentives behind the compilation of the Zǔtáng jí, and Jingxiū's perception of the text. Most importantly, this study investigates in detail two idiomatic expressions used by Jingxiū (i.e., "[cases of] shuǐhè easily arise"; "[the characters] $w \bar{u}$ and mă are difficult to distinguish"), showing their significance for understanding the preface. In addition, we demonstrate that further research is needed to support the hypothesis according to which the original Zǔtáng jí would correspond to the first two fascicles of the received Goryeo edition of 1245. Eventually, this article serves as the first part of a research summary on the textual history of the Zưtáng jí aimed at facilitating further studies on this highly important Chán text.
\end{abstract}

Keywords: Zǔtáng jí; Chán master Jìngxiū; Zhāoqìng monastery; Quánzhōu; Chán; Chán Buddhist literature; lamp records; Goryeo Buddhist canon

\section{Introduction}

The Zǔtáng jí 祖堂集 (Collection of the Patriarchal Hall; K.1503; B25, no. 144; henceforth ZTJ) is the earliest fully extant, multi-lineal witness of the Chán Buddhist literary genre that later came to be known as chuándēng lì 傳燈錄 (Records of the Transmission of the Lamp). ${ }^{1}$ Initially compiled by Jìng 靜 (d.u.) and Yún 筠 (d.u.), on whom we have little information, the text was prefaced by Chán master Jìngxiū 淨修 禪師 (892?-972) of the Zhāoqìng monastery 招慶寺 in Quánzhōu 泉州 (in present-day Quánzhōu city 泉州市, Fújiàn province 福建省). ${ }^{2}$ A dharma-heir of Băofú Cóngzhăn 保福從展 (d. 928), Jìngxiū was a second-generation disciple of Xuěfēng Yìcún 雪峰義 存 (822-908), one of the most influential Chán masters of the late Táng 唐 (618-907). ${ }^{3}$ The ZTJ inherits the patriarchal lineage of the Băolin zhuàn 寶林傳 (Chronicle of the Băolin [monastery]; B14, no. 81; henceforth BLZ) ${ }^{4}$ and the earliest stratum of the text was likely completed around the mid-tenth century. ${ }^{5}$ The sole extant witness of the ZTJ is the Goryeo 高麗 woodblock edition carved in the 32nd year (eulsa 乙巳) of the Gojong 高宗 era (1245). It was found among the extra-canonical works of the second enterprise of the Goryeo Buddhist canon (Kor. Goryeo Daejanggyeong 高麗大藏經), ${ }^{6}$ supplemented by a second preface written by a certain Gwangjun 匡儶 (d.u.). ${ }^{7}$

Along with the Dūnhuáng 敦煌 manuscripts, the ZTJ was one of the major discoveries of Chinese textual materials in the early 20th century (Zhāng 2009, p. 1). Being the earliest fully extant, multi-lineal lamp record, it is not only an important source with regard to the literary history of the Chán tradition, but also for the study of the language of the late Táng and Five Dynasties (907-960), a crucial period in the transition from Middle Chinese (zhōnggǔ hànyǔ 中古漢語) to Early Mandarin (jìndài 
hànyǔ 近代漢語) (Yanagida 1980-1984, vol. 1, p. 2; Zhāng 2009, p. 1). Indeed, as evidenced by numerous editorial notes in the text, the ZTJ was, for the most part, compiled based on various types of records, such as xinglù 行錄 ("record of conduct"; F: 28), shílù 實錄 ("veritable record"; F: 18), xingzhuàng 行狀 ("account of conduct"; F: 5), biélù 別錄 ("separate record"; F: 3), or biézhuàn 別傳 ("separate biography"; F: 1). ${ }^{8}$ In addition to these, the compilers of the ZTJ explicitly referred to the BLZ and the praise verses composed by Jìngxiū in his Quánzhōu Qiānfó xīnzhù zhūzǔshī sòng 泉州千佛新著諸祖師頌 (Eulogies for the Patriarchs newly composed by Qiānfó [Dèng] of Quánzhōu; Or.8210/S.1635; henceforth QFS). ${ }^{9}$ Eventually, other classical sources were consulted, including: (a) manuscript copies of literary compositions such as poems ( $\operatorname{sh} \bar{\imath}$ 詩), songs ( $g \bar{e}$ 歌), and stanzas ( $j \grave{\imath}$ 偈); ${ }^{10}$ (b) stele or stūpa inscriptions, ${ }^{11}$ and probably (c) Chán texts and bio-hagiographical records that circulated at the time. ${ }^{12} \mathrm{Com}-$ bined with the fact that the language and the style of the text most likely did not undergo revisions by Northern Sòng 北宋 (960-1127) literati or prior to the carving enterprise (Demiéville 1970, p. 264; Kinugawa 1998, p. 118), this makes the ZTJ one of the most valuable sources for the study of the vernacular of the late Táng and Five Dynasties and linguistic research on the development of Early Mandarin. In addition, the Goryeo edition of the ZTJ preserves many graphic variants (yiť̌ż 異體字), such as demotic characters (súzì 俗字), ancient characters (ǧ̌zì 古字), or simplified characters (jiănhuàzi 簡化字), as well as phonetic loan characters (tōngjiăzì 通假字), which appear to reflect the customs of non-official documents during these periods. ${ }^{13}$ As such, the record is also a treasure trove for the study of graphic variants and historical phonology (Zhāng 2009, p. 8; see, e.g., Kinugawa 2010b).

On the basis of recently produced XML/TEI-based diplomatic and regularized editions of the prefaces of Jingxiū and Gwangjun published on the Database of Medieval Chinese Texts, ${ }^{14}$ this paper presents, for the first time, a critically annotated English translation and comprehensive study of the first of these prefaces.

The main objective of this study is to provide a multifaceted analysis of Jingxiū's preface, including aspects of linguistics, literary studies, and textual history. Special attention is paid to the structure and linguistic features of the preface (e.g., phonetic loans, the use of syntactic and semantic parallelism, issues of intertextuality). In addition, the text is scrutinized in search of elements that can help to unravel the complex textual history of the ZTJ (e.g., date of compilation, size and contents of the original text). Eventually, the concerns and religious aspirations of Jingxiū are carefully examined and contextualized through an evaluation of previous Chán histories and his QFS. Throughout the paper, the analysis is supported by external evidence gathered from historical sources (e.g., bibliographic catalogs, official histories, gazetteers) in order to refine the information retrieved from the foreword of the abbot of the Zhāoqing monastery.

As a result, we demonstrate that despite its relative brevity, the preface not only provides a wealth of information on the circumstances and incentives that have led to the compilation of the ZTJ, but also contains precious clues about the form and contents of the original text, now lost. In this respect, we show that further research is needed to support the hypothesis according to which the "original" ZTJ in one juàn 卷 (scroll) would correspond to the first two juàn (fascicles or volumes) of the received Goryeo edition of 1245 . Most importantly, this study provides a detailed analysis of two idiomatic expressions used by Jìngxiū (i.e., "[cases of] shuìhè easily arise" 水涸(=鶴)易生, and “[the characters] $w \bar{u}$ and mă are difficult to distinguish" 烏 馬難辯(=辨)), highlighting their significance for understanding the preface. Eventually, in consideration of the fact that Jingxiū's preface illustrates well the complexity of the work as a whole, whether from the point of view of philology (e.g., variant characters, phonetic loans, intertextuality) or that of literary history (e.g., interplay of multifarious socio-religious motives, literary impetus), we argue for a more nuanced 
approach to the ZTJ that integrates different angles of study without reducing the text to one of these aspects.

Through this paper, we further provide the first part of a research summary of what is known and what remains uncertain about the ZTJ. It is the authors' wish that this will help to correct a few misconceptions about the text and facilitate further research on this complicated but highly important Chán Buddhist record.

\section{The Goryeo Edition of the ZTJ}

As is well known, the sole extant witness of the ZTJ is the Goryeo woodblock edition carved in the 32nd year of the Gojong era (1245) (Yanagida 1964, p. 12; Yanagida 1980-1984, vol. 1, p. 1). This dating is based on the following editorial note, which closes the first juàn: 「乙巳歲分司大藏都監彫造」 (“Carved by the Branch Office of the Great [Buddhist] Canon Directorate in the eulsa year") ${ }_{1}^{15}$ where the eulsa 乙巳 year corresponds to the 32nd year of king Gojong's 高宗 (1192-1259; r. 1213-1259) reign, from February 1245 to January $1246 .^{16}$

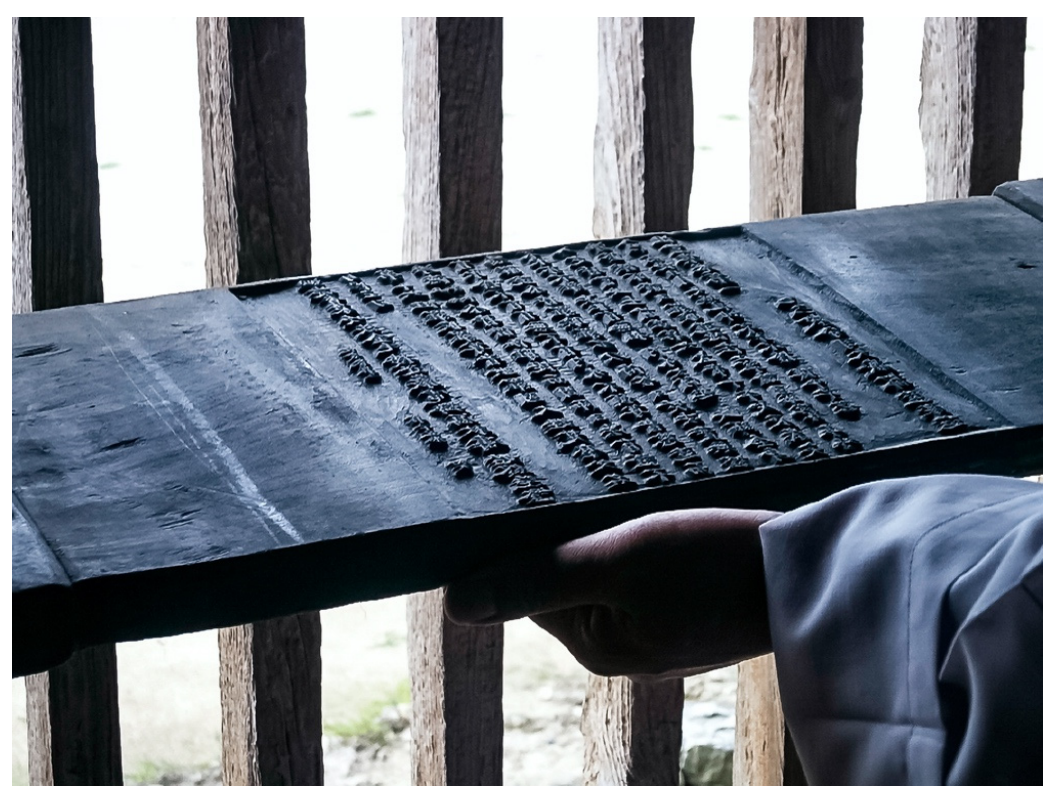

Figure 1. Last zhāng 張 (printing surface) of the first juàn 卷 (fascicle) of the ZTJ, where the inscription related to the date of the carving of the Goryeo edition (“乙巳歲分司大藏都監彫造。”) is found (photograph by Christoph Anderl).

The ZTJ was carved as part of the second Goryeo canon enterprise, later known as the Palman Daejanggyeong 八萬大藏經 (“Great [Buddhist] Canon in 80,000 [plates]"), ${ }^{17}$ or, more precisely, as part of the extra-canonical section of the Goryeo canon. ${ }^{18}$ This project was initiated by Gojong and his ministers in the 23rd year of his reign (1236), after the woodblocks of the first Goryeo canon and its supplements had been destroyed in 1232, in the wake of the Mongol incursions. ${ }^{19}$ For this purpose, the Central Directorate for the Buddhist Canon (Daejang dogam 大藏都監) was established on Ganghwa island 江華島, where the royal family and government officials had been forced to take refuge (Wu and Dziwenka 2015, p. 254). Branch offices (Bunsa daejang dogam 分司大藏都監) were established in other places to help with the carving enterprise, among which several were located in Jinju 晉州, Namhae county 南海郡 (in present-day South Gyeongsang province 慶向南道). ${ }^{20}$ The ZTJ, like the Zōngjìng lì 宗 鏡錄 (Record of the Mirror of the Source; K.1499; T48, no. 2016; compiled by Yǒngmíng Yánshòu 永明延壽, trad. 961), was likely carved in a branch office located in Jinju. ${ }^{21}$ 
The carving enterprise of the second Goryeo canon per se began as early as 1237 and it was achieved in the 38th year of Gojong's reign, i.e., in $1251 .^{22}$

After several relocations, the printing blocks that were initially stored on Ganghwa island were moved to the Haein monastery 海印寺 located on Mt. Gaya 伽耶山 (South Gyeongsang province), likely in order to avoid the potential danger of destruction by the so-called Wōkòu 倭寇, the pirates who pillaged the Chinese and Korean coastlines. ${ }^{23}$ This is where the printing blocks of the ZTJ were "discovered" at the beginning of the 20th century by Japanese scholars. ${ }^{24}$

\subsection{Format and Characteristics of the Goryeo Edition of the ZTJ}

The Goryeo edition of the ZTJ consists of 20 juàn and 385 carved zhāng 張 (printing surfaces), for a total of ca. 189,000 characters. On average, one juàn consists of around 9450 characters, with the two first juàn being the largest (respectively, ca. 12,720 and ca. 13,170 characters) ${ }^{25}$ and the two last juàn being the shortest (respectively, ca. 7460 and ca. 7500 characters). ${ }^{26}$ According to Kinugawa Kenji 衣川賢次, the printing blocks of the ZTJ have an approximate dimension of $21 \mathrm{~cm}$ (height) $\times 52 \mathrm{~cm}$ (width). ${ }^{27}$

As is the case with other woodblock editions of the Buddhist canon, the primary unit of the Goryeo edition of the ZTJ is not the woodblock, but the zhang in association with the juàn to which it belongs. This is evidenced by the carvings on the side of each woodblock. Indeed, as can be seen in the background of Figure 2, the sides are carved with the inscription "Zǔtáng 祖堂", followed by the number of the juàn and, in smaller script, the number of the printing surfaces in that juàn. For example, one inscription reads: “Zǔtáng 祖堂, wǔ 五, shíwǔ zhāng 十五丈(=張), shíliù zhāng 十六丈". ${ }^{28}$ This is also evident from the editorial inscriptions in smaller script usually found in the margin of each printing surface. For instance, for each juàn (e.g., “祖堂卷第一”, “祖 堂卷第二”), the zhāng are given a number (e.g., “第二張”, “第二十四張”), with the exception of the first zhāng of each juàn, where it is omitted. At the beginning of a new juàn, the numbering of the printing surfaces starts again. With very few exceptions (i.e., the end of several juàn), the woodblocks of the ZTJ are carved on both faces.

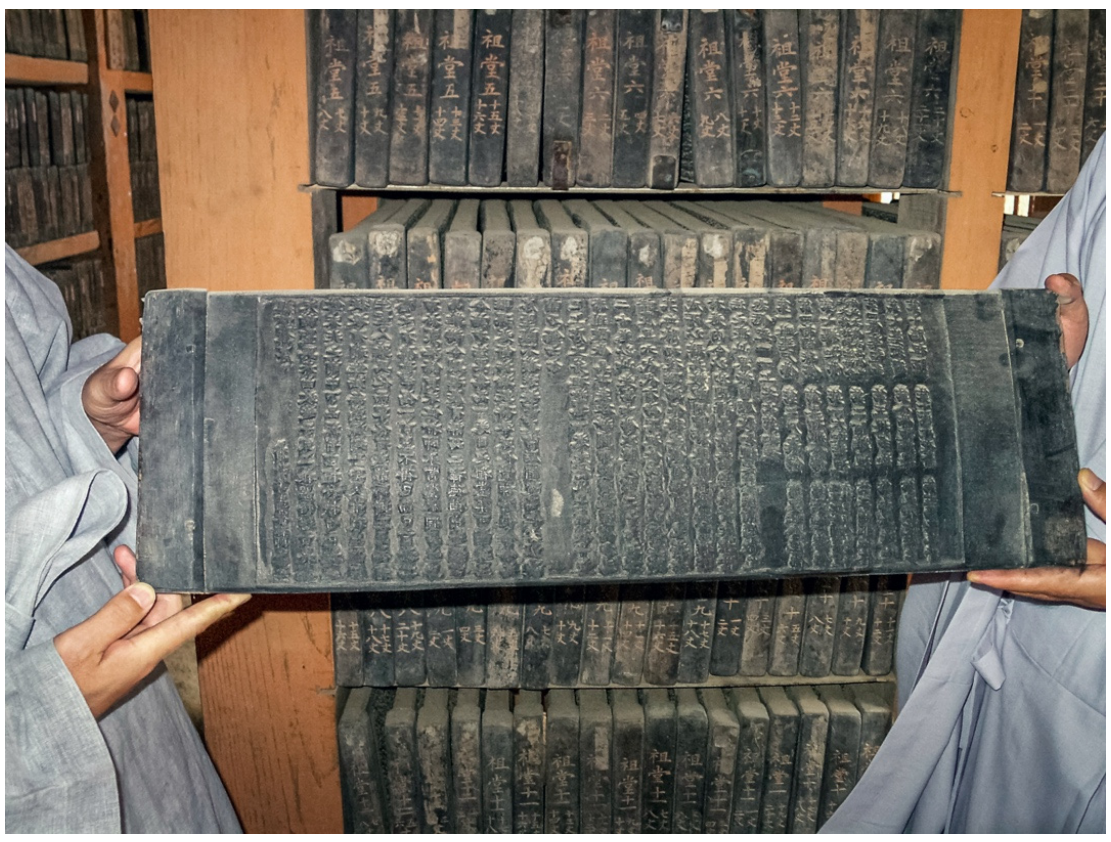

Figure 2. First zhāng of the ZTJ, which contains Jingxiū's preface (i.e., the first twelve lines on the left-hand side) and a part of the Goryeo preface, including the beginning of the table of contents, visible on the right-hand side (photograph by Christoph Anderl). 
Each zhāng normally consists of 28 vertical lines or columns, marginal editorial notes excluded..$^{29}$ This standard layout had been in use in manuscript editions and some early printed editions of the Chinese Buddhist canon (Róng 2007, p. 342; Wu 2015, p. 31). In contrast, the zhèngzàng section of the Goryeo canon usually consists of 23 columns per printing surface. Naturally, the number of columns on the last zhang of a given juàn can be lower if the juàn is finished. For example, the last printing surfaces of the first and second juàn (zhāng no. 25 in both cases) consist of 12 and 13 columns, respectively. ${ }^{30}$

In the Goryeo edition of the ZTJ, a column usually consists of 18 characters, the standard in manuscripts and some early printed editions of the Chinese Buddhist canon being 17 characters per column (Róng 2007, p. 342; Wu 2015, p. 31). This contrasts again with the zhèngzàng section of the Goryeo canon, where a standard column usually consists of 14 characters. However, as Robert E. Buswell has noted, the extra-canonical works appended at the end of the second Goryeo canon "[ ... ] show a remarkable diversity in format, ranging from 17 to 24 logographs per line." ${ }^{\prime 31}$ In addition to this, in the ZTJ, the expected number of characters per column is frequently disrupted. This can be observed, for example, in the table of contents of the Goryeo preface, in passages where inline editorial notes are inserted, or in other specific cases (e.g., gāthās, poems, songs, praise verses, end of an entry). Even in presumed regular parts of the text, it is not rare to find columns that consist of 19 or more characters (e.g., ZTJ_001-05.10, ZTJ_001-18.04, ZTJ_001-18.07). The preface by Jingxiū, however, does not show any particular feature, with the exception of the first column, which consists of the title of the preface ('Zǔtáng jí xù 《祖堂集》序, “Preface to the Collection of the Patriarchal Hall") and, separated by a space, the names and function of the preface's author, written in smaller script. ${ }^{32}$

The editorial notes referencing the juàn and the zhang are usually located on the right-hand margin of each zhāng (i.e., left-hand margin when printed). ${ }^{33}$ Below this reference, one frequently finds a name that corresponds to the name of the donors who sponsored the individual printing blocks. ${ }^{34}$ For example, at the end of the second zhāng of the first juàn, the note likely reads: 「祖堂，卷第一、第二張，仁甫。」

("Zǔtáng fascicle no. 1, printing surface no. 2, Rénfǔ"). ${ }^{35}$

Another characteristic of the Goryeo edition of the ZTJ, although not exclusive to this text, is that the character jiàn 建 is tabooed throughout the twenty juàn, usually lacking its last stroke (i.e., québ̌ 缺筆) (Yanagida 1980-1984, vol. 3, p. 1597). This was done in order to avoid the personal name of the founder of the Goryeo kingdom, Wang Geon 王建 (877-943; r. 918-943; temple name Goryeo Taejo 高麗太祖), who was also a supporter of Buddhism, and more specifically of Seon (i.e., Chán) (see, e.g., Vermeersch 2014, p. 75). Four examples are given in Table 1 below.

Table 1. Four examples of the tabooed character jiàn 建 in the Goryeo edition of the ZTJ.

\begin{tabular}{|c|c|c|c|}
\hline ZTJ_001-17.20.03 & ZTJ_001-18.11.07a & ZTJ_001-22.26.11 & ZTJ_017-10.20.11 \\
\hline$\frac{e^{2}}{2 y}$ & $\frac{-2 y+1}{5,-\frac{3}{2}}$ & & 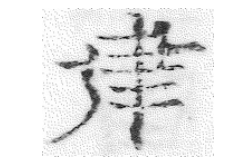 \\
\hline
\end{tabular}

The first three images correspond to the three occurrences of jiàn 建 in the first juàn, while the fourth image is the last occurrence of the character in the ZTJ, at the end of the entry of Guīshān Zhèngyuán 龜山正原 (ca. 792-869; BSPAD ID: A014172) in juàn 17.

\subsection{General Structure of the Goryeo Edition of the ZTJ}

With regard to its structure, the Goryeo edition of the ZTJ opens with the preface of Chán master Jingxiū. ${ }^{36}$ It is directly followed, on a new line, by a second preface 
authored by Gwangjun at the occasion of the carving enterprise. ${ }^{37}$ This foreword is not given any title in the text but, in secondary literature, it is frequently referred to as the Hăidōng xīnkāi yìnbăn ji 海東新開印版記 (Notes to the Korean newly edited printing blocks [of the Zǔtáng jí]). ${ }^{38}$ Eventually, the main section of the text, divided into twenty juàn, follows. The first juàn begins on the eighth column of the fourth zhāng, after Gwangjun's foreword. ${ }^{39}$ The remaining fascicles, however, systematically begin on a new printing block.

Each juàn opens and closes with an editorial note referencing the juàn in question (e.g., “祖堂集卷第一”). The closing note is sometimes followed by the number of the zhāng and/or a donor's name in smaller script. On the first line of juàn 2, a note in smaller script reads: 「於卷內, 西天并震旦一十七祖已畢。」(“Inside the fascicle, [the entries of the remaining] seventeen patriarchs of India and China are concluded."). ${ }^{40}$ Juàn 3 and 4 do not open with any special editorial note. However, from juàn 5 to 13, the fascicles open with a variation of the following comment: 「石頭下, 卷第二, 曹 溪三、四、五代法孫。」("Successors of Shítóu [Xīqiān], second juàn; third, fourth and fifth generations of the dharma-heirs of Cáoxī (i.e., Huìnéng)"). ${ }^{41}$ By contrast, juàn 14 to 20 open with a variation of the following editorial note: 「江西下, 卷第一, 曹溪 第二代法孫。」(sic., "Successors of Jiāngxī [Măzǔ], first juàn; second generation of the dharma-heirs of Cáoxī" $).{ }^{42}$ Ultimately, the Goryeo edition of the ZTJ ends with juàn 20, which is closed with the usual editorial note mentioning the juàn, the zhang, and the name of the donor. ${ }^{43}$

In total, the ZTJ contains 246 bio-hagiographical entries of figures, legendary or historical, who were associated with the Chán tradition. ${ }^{44}$ With the exception of Milinng's 米嶺 entry, i.e., the last entry recorded in the ZTJ (ZTJ_020-16.01.16), each entry begins on a new line. These entries, however, are not usually structured or laid out according to the different textual units that they contain.

\subsection{Prints and Photographic Reproductions Consulted}

The main source consulted to prepare the materials relevant for this paper was a scanned copy of what appears to be an original print of the Goryeo edition of the ZTJ that is stored at the Library of the Institute for Research in Humanities 人文科学研究 所図書室 of Kyōto University 京都大學 (Kyōto, Japan). In the library catalog of Kyōto University, the collection to which the print belongs is referenced as follows: Gāoli zàngjīng bǔyí 高麗藏經補遺 (Supplement to the Goryeo [Dae]janggyeong), Cháoxiăn Shì Hǎiming Zhuàngxióng ji 朝鮮釋海冥壯雄輯 (collected by the Joseon monk Haemyeong Jangung), Zhāohé shísān nián 昭和十三年 (13th year of the Shōwa era [1938]), yòng Cháoxiăn Hǎiyinsì cáng Gāolí kānbăn yìnběn 用朝鮮海印寺藏高麗刊板印本 (printed copy based on the Goryeo woodblocks stored at the Haein monastery in Korea), 61 cè 册 (61 volumes). The library reference of the print is Kyōdai jinbunken 京大人文研, Tōhō 東方, shi 子-XIII-419. On the case (see Figure 3), it is written: Gāolí zàngī̄ng bǔyí 高 麗藏經補遺 (Supplement to the Goryeo [Dae]janggyeong), quán shibā hán 全十八函 (13 cases in total), dì liù hán 第六函 (sixth case), sān běn 三本 (three volumes), Zǔtáng ji 祖 堂集. 


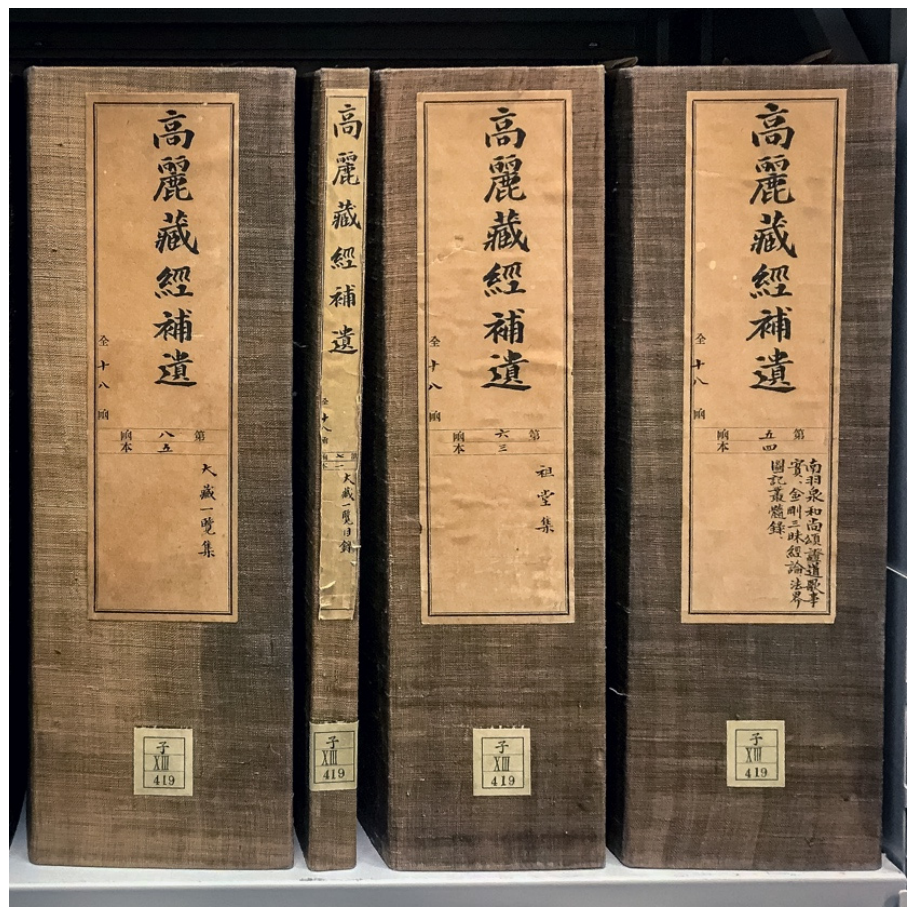

Figure 3. The case in the center of the image contains the prints of the ZTJ as stored at the Library of the Institute for Research in Humanities of Kyōto University (photograph by Christian Wittern, Kyōto University).

Inside the case, the print is bound in three volumes, corresponding to the 25th, 26th, and 27th volumes in the series. This edition has stamps from the former Tōho bunka kenkyūjo 東方文化研究所 of Kyōto University (see Figure 4), which would indicate that the print was acquired between 1938 and 1949, before the institute was integrated into the new Jinbun kagaku kenkyūjo 人文科学研究所. ${ }^{45}$

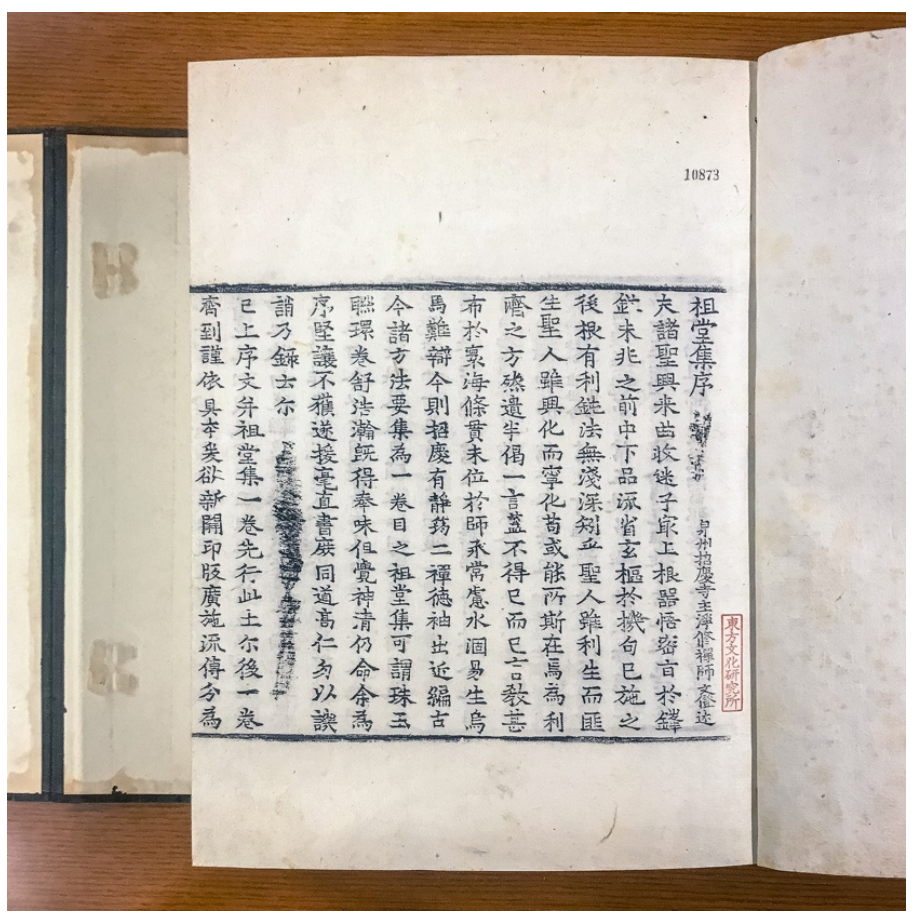

Figure 4. First half of the first zhāng of the ZTJ containing the preface of Jingxiū and the beginning of the Goryeo preface. The print of the zhāng is folded into two (photograph by Christian Wittern). 
Because the quality of the prints may vary and they are subject to small inconsistencies, it is important to consult other prints of the Goryeo edition of the ZTJ. To this end, we consulted the good-quality facsimile edition of the print stored at Hanazono University 花園大学 (Kyōto), reproduced in the Zen bunka kenkyūjo 禅文化研究 所 (The Institute for Zen Studies) edition of 1994. On the other hand, facsimiles such as that of the Shanghai Classics Publishing House 上海古籍出版社 (1994), which is ultimately based on the same print, should be used with caution since modifications were made to the reproduction at an earlier stage (e.g., addition of strokes to damaged characters, of parentheses). ${ }^{46}$

In addition to the prints and facsimile reproductions listed above, the following editions of the ZTJ and its first preface were consulted: (Yanagida 1953 [Zǔtáng ji xù 祖堂集序, p. 36]; Yanagida 1964 [Zǔtáng jí xù, pp. 13-18]; Fóguāng dàzàngjīng biānxiū wěiyuánhuì 1994; Wú and Gù 1996; Zhāng 2001; Sūn et al. 2007; Zhāng 2009; Kinugawa 2010a [Zǔtáng jí xù, pp. 8-9]; Kinugawa 2010b [Zǔtáng jí xù, pp. 315(2)314(3)]).

To this day, the best annotated editions of the complete text of the ZTJ are those of Sūn Chāngwǔ 孫昌武, Kinugawa Kenji 衣川賢次, and Nishiguchi Yoshio 西口芳男 (Sūn et al. 2007) and Zhāng Měilán 張美蘭 (Zhāng 2009).

The preface for which we provide a translation in the following section is the first preface of the ZTJ. It was composed by Chán master Jingxiū, also known as Wéndèng, at the request of Jìng and Yún (i.e., the original compilers of the ZTJ), who presented their text to him at the Zhāoqing monastery in Quánzhōu around the midtenth century.

\section{The Preface of Chán Master Jìngxiū}

3.1. Edition and Annotated Translation

祖堂集序 47

泉州招慶寺主淨修禪師文僜述

夫諸聖興來, 曲收迷子。最上根器, 悟密旨於鋒鋩未兆之前。中下品流, 省 玄樞於機句已施之後。根有利鈍, 法無淺深。知乎聖人雖利生而匪生, 聖人 雖興化而寧化。苟或能所斯在，焉為利濟之方？然遺半偈一言，蓋不得已而 已。言教甚布於寰海, 條貫未位於師承。常慮水涸易生, 烏馬難辯。今則招 慶有靜、筠二禪德, 袖出近編古今諸方法要, 集為一卷, 目之《祖堂集》。可 謂珠玉聯環, 卷舒浩瀚。既得奉味, 但覺神清。仍命余為序, 堅讓不獲, 遂 援毫直書。庶同道高仁，勿以譏誚。乃錄云爾。

Preface to the Zǔtáng jí ("Collection of the Patriarchal Hall") $)^{48}$

Composed by Wéndèng, Chán master Jìngxiū,abbot of the Zhāoqìng monastery in Quánzhōu.

As for the sages who have arisen [in this world], they have extensively received the deluded sons. ${ }^{49}$ [Those with] the foremost predispositions awaken to the secret purport before the incisiveness [of the sages] has been displayed. ${ }^{50}$ [Those with] medium or low aptitudes understand the mysterious essence after it has been exposed through critical phrases. ${ }^{51}$ The predispositions [of people] are either sharp or dull, but the dharma is without [differentiation between] shallow and deep. How much more, even if the sages benefit sentient beings, there are [in reality] no [such things as] sentient beings, ${ }^{52}$ and even if the sages engage in transforming [them], how could there be [any] transforming ${ }^{53}$ If [a distinction between] agent and patient exists, ${ }^{54}$ how could this constitute a method to help [sentient beings] ${ }^{55}$

This being the case, [the sages] have handed down half a gāth $\bar{a}$ and an utterance because they had no alternatives. Their oral teachings have abundantly spread throughout the world, but an arrangement has not yet been set up concerning the 
succession of the masters. ${ }^{56}$ [Yet,] I am often concerned that [cases of] shuihè (water crane $)^{57}$ easily arise and that [the characters] $w \bar{u}$ 烏 (crow) and mă 馬 (horse) are difficult to distinguish. ${ }^{58}$

But now, at the Zhāoqìng monastery, the two Chán-worthies ${ }^{59}$ Jìng and Yún have presented ${ }^{60}$ these recently compiled essentials of the dharma of the past and the present and from all regions, which they collected into one scroll and titled Zǔtáng ji ("Collection of the Patriarchal Hall") ${ }^{61}$ It can be said to be like pearls and jade gemstones stringed in a chain, ${ }^{62}$ a volume which is full of riches. ${ }^{63}$ Having received this entrusted delicacy, I just felt that my mind was refreshed. ${ }^{64}$

[Jìng and Yún] repeatedly requested me to write a preface, which I firmly declined, but without success. Consequently, I grabbed a brush and wrote straightforwardly, ${ }^{65}$ with the hope ${ }^{66}$ that the virtuous ones, fellow practitioners of the [Buddhist] Way, will not deride [me] for it. ${ }^{67}$ The preface was recorded like this. ${ }^{68}$

\subsection{The Author of the Preface}

As evidenced by the header, the original preface of the ZTJ was composed by Chán master Jìngxiū,${ }^{69}$ or Wéndèng ${ }^{70}$ who introduces himself as abbot of the Zhāoqìng monastery in Quánzhōu. Also known as Qiānfó Dèng 千佛僜 and Xĩngdèng 省僜, ${ }^{71}$ Jìngxiū is the author of the Quánzhōu Qiānfó xīnzhù zhūzǔshī sòng 泉州干佛新著諸祖 師頌 (Eulogies for the Patriarchs newly composed by Qiānfó [Dèng] of Quánzhōu; S.1635; hereafter QFS), a collection of thirty-eight tetrasyllabic octave eulogies (sòng 頌) or praise verses (zàn 讚) ${ }^{72}$ written for the patriarchs and masters of the Chán tradition, thirty-six of which were appended at the end of their respective entries in the ZTJ. ${ }^{73}$ In addition, the Jingdé chuándēng lù 景德傳燈錄 (Jǐngdé [era] Record of the Transmission of the Lamp; T51, no. 2076; compiled by Dàoyuán 道原 (d.u.) ca. 1004, edited by Yáng Yì 楊億 (974-1020) et al. by 1009; hereafter JDCDL) records two regulated heptasyllabic octave verses (qülù 七律) composed by him in its juàn $29 .{ }^{74}$ Among the most informative sources on Wéndèng are: (1) the ZTJ, (2) the Zìyún käishì zhuàn 紫雲開士傳 (Biographies of the founders of the Zìyun [monastery]), ${ }^{75}$ and (3) the Quánzhōu Kāiyuánsi zhì 泉州開元寺志 (Gazetteer of the Quánzhōu Kāiyuán monastery). ${ }^{76}$

According to these sources, Wéndèng's family name was Ruăn 阮 and he was a native of Xiānyóu county 仙游縣 of Quánzhōu prefecture. ${ }^{77}$ He became a monk at the Pútí temple (or cloister) 菩提院 of the Lónghuá monastery 龍華寺 and took the full precepts at the age of twenty ${ }^{78}$ These sources claim that Wéndèng initially investigated in detail the vinaya ("lübù 律部") and that he regularly lectured on the “shàngshēng 上生", i.e., the Fóshuō Guān Mîlè púsà shàngshēng Dōushuàitiān jīng 佛說 觀彌勒菩薩上生兒率天經 (Sütra on the contemplation of Bodhisattva Maitreya's rebirth in Tusita Heaven preached by the Buddha; T14, no. 452). ${ }^{79}$ After having presumably heard that Chán was the superior tradition (“我聞禪宗最上”), Wéndèng then decided to go and study under the guidance of Chán masters. The ZTJ recounts that he first met with Xuěfēng Yìcún's disciples Gǔshān Shényàn 鼓山神晏 (d. 936 944?), Chángqìng Huiléng 長慶慧稜 (854-932), and Xuánshā Shībèi 玄沙師備 (835-908). ${ }^{80}$

Subsequently, Wéndèng went to study with Cóngzhăn and became his dharmaheir. ${ }^{81}$ Wéndèng was therefore a second-generation dharma-heir of Yìcún, ${ }^{82}$ and a successor in the "southern" lineage of Huìnéng in the Qīngyuán Xíngsī 青原行思 and Shítóu Xīqiān 石頭希遷 branch, as portrayed in the ZTJ (Yáng 2001, p. 3). In this regard, it should be noted that at the end of the Táng and during the Five Dynasties, the lineage of Yìcún was flourishing in the prefectures of Fúzhōu 福州, Zhāngzhōu 漳州, and Quánzhōu (Suzuki 1975; Yáng 2006b, pp. 477, 480). According to Zhāng Měilán, Yìcún's lineage was, at the time, not only the most prosperous Chán lineage of the region, but also of the whole Chinese territory. ${ }^{83}$ Naturally, the prominence of 
the Chán circles that formed around Yìcún and his successors did not solely rest on the charisma of its forebearers, but was closely linked to the support of local rulers and officials of the Mĩn 閩 (909-945) and Southern Táng 南唐 (937-976) kingdoms. ${ }^{84}$

After having studied with Cóngzhăn, Wéndèng set out to travel in the regions of Wú 吳 and Chŭ 楚 (i.e., the Jiāngnán 江南 region), including Mt. Héng 衡山 (i.e., Nányuè 南获). ${ }^{85}$ Eventually, he returned to Quánzhōu, where he served as abbot of several Buddhist monastic institutions (see below). According to the Zìyún kāishì zhuàn, Xú Xuàn 徐鉉 (916-991) praised his merit at the court and Zhào Kuāngyìn 趙 匡胤 (927-976; r. 960-977; temple name Sòng Tàizǔ 宋太祖) subsequently conferred on him the name Zhēnjué 真覺. In the fifth year of the Kāibǎo 開寶 era (972), Wéndèng passed away, reportedly due to illness, and the Ruìguāng 瑞光 stūpa was erected for him. ${ }^{86}$

In Quánzhōu, Wéndèng first served as abbot of the Qiānfó temple 千佛院 of the Quánzhōu Kāiyuán monastery 泉州開元寺. The latter was founded by Huáng Shǒugōng 黃守恭 (629-712) in the second year of the Chuígóng 垂拱 era of the Táng (686) and was, at the time, known as the Liánhuā monastery 蓮花寺. ${ }^{87}$ After several modifications, during the reign of Lǐ Lōngjī 李隆基 (685-762; r. 713-756; temple name Táng Xuánzōng 唐玄宗), in the 26th year of the Kāiyuán 開元 era (738), the monastery was renamed to Kāiyuán monastery 開元寺. ${ }^{88}$ With regard to the Qiānfó temple, the Zìuún kāishì zhuàn records that it was built during the Tiānchéng 天成 era (926-930) of the Later Táng 後唐 by Wáng Yánbīn 王延彬 (886-930), nephew of Wáng Shěnzhī 王審知 (862-925) and cìsȟ̌ 刺史 (prefect) of Quánzhōu prefecture. ${ }^{89}$ Wéndèng was invited by Wáng Yánbīn to serve as its abbot and kept his office there for over ten years. ${ }^{90}$

Thereafter, in the beginning of the first year of the Kāiyùn 開運 era (944) of the Later Jìn 後晉 (936-947), Wéndèng was invited by Huáng Shàopō 黃紹頗 (d. 944), then cìsh $̌$ of Quánzhōu prefecture, to serve as abbot of the Zhāoqìng monastery. ${ }^{91}$ Huáng Shàopō had been installed as cìsȟ̌ by Zhū Wénjìn 朱文進 (d. 945; r. 944-945), former zhǐhū̄sȟ̌ 指揮使 (military commander) of the Gǒngchén 拱宸都 military corps, who had led an insurrection against Wáng Yánxī 王延羲 (d. 944; r. 939-944; temple name Mĩn Jĩngzōng 閩景宗), ruler of the Mĩn kingdom..$^{92}$ Shortly after Wéndèng became abbot of the Zhāoqìng monastery, Zhū Wénjìn bestowed on him the name Chán master Míngjue 明覺禪師. ${ }^{93}$ In the 11th month of the first year of the Kāiyùn era (944), the Zhāoqìng monastery was destroyed by fire when Liú Cóngxiào 留從效 (906-962) and a militia of local men regained control over Quánzhōu prefecture in favor of the Wáng family and had Huáng Shàopō executed. ${ }^{94}$ Two years later, after the fall of the Min kingdom in ca. 945 and the absorption of a large portion of its territories by the Southern Táng 南唐, Liú Cóngxiào was appointed cìshǐ of Quánzhōu prefecture by Lǐ J̌ng 李璟 (916-961; r. 943-961; temple name Táng Yuánzōng 唐元宗). ${ }^{95}$ Eventually, in the seventh year of the Băodà 保大 era of the Southern Táng (949), an event precipitated the creation of the Qīngyuán military office 清源軍 by Lǐ Jing, who appointed Liú Cóngxiào as its jiédùsȟ̌ 節度使 (military commissioner). ${ }^{96}$ It was perhaps around this time that the latter built a monastery in the southern garden of his secondary residence and invited Wéndèng to serve as its abbot. ${ }^{97}$ According to Kinugawa, it was between this event and the composition of the ZTJ's preface that Liú Cóngxiào conferred on Wéndèng the name Chán master Jìngxiū 淨修禪師..$^{98}$ Wéndèng probably kept his office as abbot of the monastery built by Liú Cóngxiào until he passed away in the fifth year of the Kāibăo era of the Northern Sòng (972). 


\section{Analysis and Discussion of Chán Master Jìngxiū's Preface}

\subsection{Issues of Textual History}

Although relatively short, the preface of Wéndèng constitutes a precious source for unravelling an essential part of the textual history of the ZTJ. Two sections in particular offer valuable information: (1) the header and (2) the opening sentence of the third section of the preface, as laid out in the translation.

First, the header (“泉州招慶寺主淨修禪師文僜述”) informs us that the preface of the ZTJ was written by Wéndèng (a) after he had become abbot of the Zhāoqìng monastery and (b) after he had received the dharma-name Chán master Jìngxiū. As noted above, Wéndèng was invited by Huáng Shàopō to serve as abbot of the Zhāoqìng monastery in the beginning of the first year of the Kãiyùn era of the Later Jìn (944). Moreover, it is probable that Liú Cóngxiào conferred on him the dharma-name Chán master Jìngxiū sometime between the seventh year of the Băodà era of the Southern Táng (949) and his own death in 962. Therefore, we must conclude that Wéndèng's preface was likely written after 949 .

Incidentally, six passages in the first and second juàn of the ZTJ identify the "present" as the tenth year of the Băodà era (952) ${ }^{99}$ The first of these, which appears in the entry of Śākyamuni 釋迦牟尼 in juàn 1, goes as follows:

自如來入涅槃壬申之歲, 至今唐保大十年壬子歲, 得一千九百一十二年。教 流漢土，迄今壬子歲，凡經八百八十六年矣。

From the Tathāgata's entering into nirvāna in the Rénshēn year up to now in the tenth year of the Băodà era (952) of the [Southern] Táng, [i.e.,] Rénzǐ year, there have been 1912 years. As for when the [Buddhist] teachings spread to the Hàn territory up to the present Rénzǐ year, in total 886 years have passed. ${ }^{100}$

The second passage appears at the end of Bodhidharma's 菩提達摩 entry in the second juàn. ${ }^{101}$ Eventually, the four remaining passages, which share the same formula (“迄今唐保大十年壬子歲”), can be found at the end of the entries of Huikě 慧可, Sēngcàn 僧玻, Hóngrěn 弘忍, and Huìnéng 慧能 in the second juàn. ${ }^{102}$ This identification of the present with the tenth year of the Băodà era can hardly be regarded as a coincidence and this is why Japanese scholars have assumed that the ZTJ, as initially compiled by Jìng and Yún, was completed and prefaced by Wéndèng around $952 .{ }^{103}$

Second, the opening sentence of the third section of the preface (“今則招慶有靜、 筠二禪德, 袖出近編古今諸方法要, 集為一卷, 目之《祖堂集》。”) informs us that: (a) the text had been recently compiled by Jing and Yún and that it was presented to Jìngxiū at the Zhāoqìng monastery; (b) that it was conceived as a collection of the "essentials of the dharma" from the past and the present and from various regions; (c) that it was compiled in one scroll; and (d) that Jing and Yún gave it the title Zǔtáng ji, "Collection of the Patriarchal Hall". ${ }^{104}$

Unfortunately, Wéndèng is very elusive with regard to Jìng and Yún, who are mentioned with abbreviated names only (Demiéville 1970, p. 266). In this sentence, they are referred to as two "Chán-worthies" or "virtuous [practitioners] of Chán" (chándé 禪德). This term, already in use in early Chinese Buddhist writings, was originally a contraction of chán dàdé 禪大德, i.e., a term of respect for persons of "great virtue" who engage in the practice of a type of meditation. ${ }^{105}$ With the emergence of Chán as a movement, the term came to be used as a form of address and respect for Chán monks. ${ }^{106}$ Combined with subsequent passages (“既得奉味”, “仍命余為序”), it is relatively clear, as Zhāng Měilán points out, that Wéndèng held Jing and Yún in high regard (see Zhāng 2009, p. 6, n. 5). In this respect, while Yanagida Seizan 柳 田聖山 suggested that they were disciples of Wéndèng, ${ }^{107}$ Yáng Zēngwén 楊曾文 has argued that, in view of the terminology used by the latter, they were probably not his direct disciples but rather Chán monks of similar status, residing (temporarily?) at 
the Zhāoqìng monastery, both learned and enjoying good reputation. ${ }^{108}$ Eventually, it should be noted that Yanagida suggested that Jing and Yún were Korean monks. However, as he himself admitted, there is no evidence to confirm or invalidate this hypothesis. ${ }^{109}$

The next element of importance in terms of textual history concerns the nature of Jìng and Yún's compilation. In this respect, Wéndèng informs us that the ZTJ was conceived as a collection of the "essentials of the dharma" (făyào 法要). In the ZTJ, the first occurrence of this term is in the entry of Samghanandi 僧伽難提, the putative seventeenth patriarch of India, where it is equated with the terms fól li 佛理 ("principle(s) of the buddhas") and fóyi 佛義 ("intents of the buddhas"). ${ }^{110}$ Făyào therefore not only refers to the teachings of a master, but to the supposed gist of his instructions. ${ }^{111}$ Elsewhere in the text, we find the fourth patriarch Dàoxin 道信 (580-651) transmitting his făyào to Niútóu Făróng 牛頭法融 (594-657), upon which the latter is said to be purified from the afflictions that he was still suffering from. ${ }^{112}$ From the point of view of the tradition, the "essentials of the dharma" therefore potentially have a transformative effect on their recipient(s). ${ }^{113}$ Eventually, from the concluding passage of the (unusually) long entry of Yăngshān Huijì 仰山慧寂 (807-883) in juàn 18, we also know that these făyào could be written down and compiled in dedicated records. ${ }^{114}$ Yanagida, who dedicated a good portion of his life to researching the ZTJ, viewed these transformative exchanges or "encounter dialogues" as the most important underlying theme of the text. ${ }^{115}$ In line with this, John Jorgensen also noted that the ZTJ's entry of Huìnéng, for example, displayed a penchant for introducing doctrinal issues, which were less present in previous hagiographical accounts of the sixth patriarch's activities (see Jorgensen 2005, pp. 656-57). Jiă Jìnhuá 賈晉華 also rightfully noted that it is incorrect to state that the materials found in texts like the ZTJ and the $J D C D L$ were created or forged by Chán monks of the late Five Dynasties or the Sòng, although they manifestly underwent a process of selection and editing (Jia 2006, p. 52). As such, one should be careful not to reduce the ZTJ to a text that would have been specifically fabricated for sectarian purposes.

Returning to the preface, Wéndèng clarifies that these făyào were collected from "the past and the present, and from all regions" (gǔjīn zhüfäng făyào 古今諸方法要). Were we to interpret this passage literally, the sources gathered by Jing and Yún should not have been restricted to either India or China, or to one region of the Chinese territory (e.g., Quánzhōu prefecture). In addition, their compilation should not have ended, for example, with Huìnéng or his first- and second-generation dharmaheirs, like the BLZ. The phraseology rather suggests that the ZTJ also included materials related to more contemporary figures, perhaps local or locally celebrated Chán masters who were active in the 9th century up to the first half of the 10th century, i.e., the "present" of the compilation. ${ }^{116}$ This being the case, while it would not be incompatible with the title of the work and the information gathered on the function of the patriarchal halls in the late Táng and early Sòng, ${ }^{117}$ evidence is still lacking in this respect and the one-scroll format of the text would restrict the possible coverage of Chán masters.

The last two pieces of information that can be retrieved from Wéndèng's preface in terms of textual history are the fact that Jing and Yún's collection consisted of one scroll and that "Zǔtáng jí" was its original title. Because the title of the work has remained unchanged over the course of time, it will not be discussed further here. This is not true, however, of the format of the text, since the extant witness of the ZTJ, the Goryeo edition, consists of no less than twenty juàn.

That the ZTJ at one stage consisted of only one juàn is confirmed by the first line of the Goryeo preface, which reads as follows: 「已上序文并《祖堂集》一卷, 先行此 土。」 ("The above preface, together with the Zǔtáng jí in one scroll, first made their way to this land (i.e., the Goryeo kingdom)"). ${ }^{118}$ Furthermore, we have external ev- 
idence for this in two works of the Sòng dynasty. The first is the Chóngwén zǒngmù 崇文總目 (General Catalogue of the Chóngwén [Imperial Library], 1041), which records an edition of the ZTJ in one scroll in its Shish ù lèi zhōng 釋書類中 ("Category of Buddhist writings, Part Two") section. ${ }^{119}$ The second reference is found in the Tōngzhi 通志 (Comprehensive Record, 1161), the encyclopedic work of Zhèng Qiáo 鄭樵 (11041162). ${ }^{120}$ With the format of the initial collection confirmed, one question arises: what kind of materials did the ZTJ originally contain and how did it differ from the received Goryeo edition?

From Wéndèng's preface, it can be surmised that the type of materials contained in the ZTJ in one scroll was similar in nature to that of the Goryeo edition, i.e., a collection of sources related to figures associated with Chán, which was thought to be representative of their teachings. Considering its size, however, it must have covered much fewer figures than the received text. First, we know from the passages that identify the present as the Rénzi year or tenth year of the Băodà era (952) that the original ZTJ included materials related to Śākyamuni, Bodhidharma, Huikě, Sēngcàn, probably Dàoxìn, Hóngrěn, and Huìnéng. In addition, because these passages are found in the first two fascicles of the Goryeo edition, where the BLZ is explicitly cited as a source, it is generally assumed that the collection also included materials related to all of the Chán patriarchs listed in the BLZ. ${ }^{121}$

If we follow this reasoning, it should be noted that, in 1980, Shiina Kōyū 椎名 宏雄 had already found evidence that six first-generation and two second-generation disciples of Huìnéng had an entry, or, at the minimum, were mentioned, in the nonextant tenth juàn of the BLZ. These Chán masters are: Nányuè Huáiràng 南嶽懷讓 (677744), Yǒngjiā Xuánjué 永嘉玄覺 (665-713), Sīkōng Běnjìng 司空本淨 (667-761), Cáoxī Lìngtāo 曹溪令鞱 (666/671?-760), Nányáng Huìzhōng 南陽慧忠 (675-775), Hézé Shénhuì 荷澤神會 (684-758), Shítóu Xīqiān 石頭希遷 (701-791), and Mǎzǔ Dàoyī 馬 祖道一 (709-788). ${ }^{122}$ With the exception of Lìngtāo, all of them have an entry in the Goryeo edition of the ZTJ. Furthermore, while Qīngyuán Xíngsī 青原行思 (671-741) is absent from this list, he was nonetheless mentioned in the supposed entry of Shitou and identified as the master to whom Shítóu succeeded. ${ }^{123}$ In light of this information, it is legitimate to ask oneself if, like the patriarchs, these masters had an entry in the original ZTJ or not.

Unfortunately, this question is difficult to answer. For instance, in Huáiràng's entry in the ZTJ, the short biographical introduction and the ensuing textual unit are almost identical to the extant quotes of his entry in the BLZ. ${ }^{124}$ Other passages of the $B L Z$ related to Huáiràng, which survive only in fragments, can be found in the ZTJ as well, with only minor variations. ${ }^{125}$ On the other hand, the quotes of the $B L Z$ retrieved for Xuánjué, Běnjìng, Huìzhōng, and Shénhuì are too succinct to elaborate on their relations with the ZTJ. Eventually, only portions of the short fragments on Shítóu and Mǎzǔ overlap with sections of their entries in the ZTJ, with variations. As a result, we cannot determine with a sufficient degree of certainty if sources related to Huìnéng's disciples were included in the ZTJ in one scroll or not. Even in the case of Huáiràng, it cannot be excluded that the materials were added at a later stage based on the $B L Z$ or another source similar in content.

The second text that is important to consider with regard to the textual history and possible contents of the original ZTJ is the QFS, a collection of thirty-eight praise verses composed by Wéndèng, which antedated his preface to the ZTJ ${ }^{126}$ The first thirty-three verses were written for the Chán patriarchs listed in the $B L Z$ and the five remaining ones were composed for Chán masters of the lineage of Huinéng, who, as noted above, likely appeared in the tenth juàn of the BLZ. In the QFS, the latter are referred to as Nányuè Ràng 南嶽讓, Jízhōu Xíngsī 吉州行司, National Preceptor Huìzhōng 國師惠忠, Shítóu 石頭, and Jiāngxī Mă 江西馬, all with the epithet héshàng 和尚 ("preceptor, teacher"). ${ }^{127}$ According to the preface of the QFS, written 
by a certain Huìguān 慧觀 (d.u.), monk on Mt. Zhōngnán 終南山, located south of Cháng'ān 長安 (present-day X'̄īann city 西安市), it was at Huìguān's request that Wéndèng composed the praise verses, with an explicit reference to the BLZ. ${ }^{128}$ With the exception of Huáiràng and Shítóu, the verses of the QFS were all appended at the end of the corresponding entries in the ZTJ. Furthermore, it should be noted that the ZTJ includes six supplementary eulogies written by Wéndèng. These were composed for: Dàowú Yuánzhì 道吾圓智 (769-835), Déshān Xuānjiàn 德山宣鑒 (780?865), Dòngshān Liángiè 洞山良价 (807-869), Xuánshā Shībèi 玄沙師備 (835-908), Chángqìng Huìléng 長慶慧稜 (854-932), and Nánquán Pǔyuàn 南泉普願 (748-834). ${ }^{129}$ In total, the received ZTJ records forty-two of Wéndèng's praise verses. ${ }^{130}$

Yanagida believed that there was a strong connection between the QFS and the ZTJ and that the composition of the latter was tied to that of the former. ${ }^{131}$ Kinugawa, on the other hand, has tempered this view, pointing out, among other things, that if such was the case, it would be relatively strange that Wéndèng would not allude to this in his preface. Building on his research on the different layers of the text (see below), Kinugawa even suggested that this omission points to the fact that the verses of Wéndèng were not yet included in the ZTJ in one juàn. ${ }^{132}$ What is certain, however, is that, in view of the above, the compilers of the original ZTJ must have been familiar with sources related to a few first- and second-generation disciples of Huìnéng. However, at present, evidence is still lacking as to whether or not these figures, mentioned in both the $B L Z$ and the QFS, already appeared in the earliest stratum of the text.

Returning to the question of the extent of the original ZTJ, we know from Wéndèng's preface that it was compiled in one scroll. This manifestly stands in contrast with the received Goryeo edition in twenty juàn, which is the basis of all modern research on the text. Puzzled by this issue, Yanagida put forward the hypothesis of a "long scroll" that had not yet been divided into proper juàn-type units and on which the characters would have been written in small script, in a very dense manner (see Yanagida 1980-1984, vol. 3, pp. 1599-600). Although in contradiction with Chán manuscripts retrieved from Dūnhuáng, Yanagida's theory was adopted by Yáng Zēngwén in his Táng Wǔdài Chánzōng shř 唐五代禪宗史 (A History of the Chán School during the Táng and Five Dynasties) (see Yáng 2006b, p. 479). In fact, this problem was solved by Kinugawa upon close examination of the opening sentence of the Goryeo preface. ${ }^{133}$ The passage is as follows:

已上序文并《祖堂集》一卷, 先行此土。爾後十卷齊到。謹依具本, 爱欲新 開印版, 廣施流傳, 分為二十卷。134

The above preface, together with the Zǔtáng jí in one juàn, first made their way to this land (i.e., the Goryeo kingdom). Thereafter, [a version in] ten juàn jointly arrived. Diligently relying on this complete volume, we thereupon wished to newly edit [it as] a printing block [edition] in order to circulate [the work] on a large scale, and [for this purpose] we divided it into twenty juàn. ${ }^{135}$

On the Goryeo woodblock, in “爾後十卷齊到”, the graph shí 十 ("ten") was damaged in a such way that it looked like a $y \bar{\imath}$ - ("one"), especially when printed. Considering the above passage, it can be inferred that the initial ZTJ in one scroll was expanded to ten scrolls, a version that was then used by the editors of the Goryeo canon and further divided into twenty fascicles for the purpose of the carving enterprise. ${ }^{136}$ Since this important discovery was published by Kinugawa (cf. Kinugawa 1998), ${ }^{137}$ we know that it is inappropriate to equate the initial ZTJ as prefaced by Wéndèng with the received Goryeo edition. One question, however, remains: if the ZTJ was originally compiled in one scroll, what was the extent of that scroll?

At present, only hypotheses can be formulated in answer to this question. First, according to Róng Xīnjiāng 榮新江, it is estimated that, among Dūnhuáng manuscripts, 
the average diameter of a rolled-up scroll is around one cùn 寸 (i.e., $3.3 \mathrm{~cm}$ ) (Róng 2007, p. 344; cf. Rong 2013, p. 489). While Dūnhuáng might not necessarily be representative of manuscript culture in other regions, the theory of a "long scroll" appears all the more unlikely in light of this information. In fact, among the Chán histories retrieved from Dūnhuáng, the Lìdài făbăo jì is probably the longest text in one juàn, consisting of ca. 25,000 characters. ${ }^{138}$ Compared with the Goryeo edition of the ZTJ, this would correspond, for example, to the first two juàn of the text (ca. 23,800 characters, prefaces excluded). Fittingly, according to Gwangjun's preface, it can be surmised that these two juàn originally corresponded to the first juàn of the ten juàn version of the ZTJ, prior to its division. Incidentally, as we have seen, the passages that identify the present as the tenth year of the Băodà era and those that explicitly cite the BLZ all appear in the first and second fascicles of the received Goryeo edition. Whether to see this or not as an indication of the scope of the original ZTJ is a matter that should be left to the appreciation of each until concrete evidence is found.

Kinugawa Kenji, the leading expert on the ZTJ, believes that the compilation of Jìng and Yún more or less corresponds to the first two juàn of the Goryeo edition. ${ }^{139}$ While we partly agree with this hypothesis, it also raises a number of questions. For instance, if the text was completed by the time Wéndèng wrote his preface, one may wonder why the ZTJ in one juàn would be concluded with the entry of Huìnéng. In addition, if Jing and Yún had used the $B L Z$ as a source for the thirty-three patriarchs, why would materials related to Chán masters such as Xíngsī, Huáiràng, Huìzhōng, Shítóu, and Măzǔ, all mentioned in the $B L Z$, be omitted? In fact, Wéndèng's preface, his QFS, and the presumed content of the lost juàn of the $B L Z$ (and its continuation by Wéijìng) all seem to suggest that the original ZTJ may have also contained materials related to later Chán figures. In this regard, we concur with the earlier observations made by John Jorgensen. ${ }^{140}$ This being the case, both hypotheses remain possible at this stage, and while this issue might be difficult to solve, linguistic research on the ZTJ could potentially offer additional evidence to shed light on the early layer of the text. These studies, however, will need to take into consideration the current results of textual history and be mindful of methodological issues.

\subsection{Concerns of Wéndèng and Possible Incentives behind the Compilation of the ZTJ}

Another topic of importance regarding the preface of Wéndèng relates to the incentives behind the compilation of the ZTJ. The abbot of the Zhāoqing monastery specifically raises a few concerns against which Jing and Yún's recent collection is contrasted.

First, Wéndèng explains that although the oral teachings of the "sages" (i.e., the buddhas, the bodhisattvas, and the Chán masters) have spread throughout the world (yánjiào shén bù yú huánhăi 言教甚布於寰海), a proper arrangement has not yet been set up with regard to the master to disciple transmission (tiáoguàn wèi wèi yú shīchéng 條貫未位於師承). As noted in the translation, the second part of this sentence can either be interpreted as a general claim concerning the absence of a system to record and establish the lines of transmission of the Chán masters or, more specifically, as a statement regarding the fact that the Chán masters' teachings had not yet been arranged according to these lineages. While the second option is more likely considering the general context of the preface and its emphasis on the teachings of the sages (e.g., rán wèi bàn jì yĩ yán 然遺半偈一言), these two aspects are in fact intricately linked to one another in the context of Chán literature. For instance, one particular feature of Chán histories is precisely their ingenuity in combining the adoption of preestablished lineages and the concomitant origination of (new) lines of transmission, whether factual or fictitious, which the texts aim at legitimizing.

If we follow the second interpretation, one may therefore wonder if the term yánjiào 言教 in the preceding clause should not be understood as pointing to written records of "oral teachings", somehow equivalent to the yǔběn 語本 (lit. "books of say- 
ings"), for only written records could effectively be arranged according to the lineages of the Chán masters. As a matter of fact, this was already suggested by Yanagida in his monumental paper on the development of the yǔlù 語錄 ("records of sayings") genre. ${ }^{141}$ To be sure, there is little doubt that the teachings of famed masters were also transmitted orally in the form of maxims or short narratives, which were likely further discussed and commented upon (see McRae 2003, pp. 12, 83, 99-100). However, it is more likely that yánjiào refers here to the oral teachings of Chán patriarchs (and masters), which circulated independently in the form of notes or records.

Subsequently, Wéndèng mentions that this situation is aggravated by the fact that mistakes easily occur. In particular, the author of the preface points to: (a) issues pertaining to the (oral) transmission of the teachings, and (b) errors linked to graphic confusions.

As noted in the translation, in the clause cháng lù shuìhè yì shēng 常慮水涸易生 (lit. "I am often concerned that [cases of] shuihè (i.e., water crane) easily arise"), the graph 涸 is a phonetic loan character (tōngjiǎzì; in this case, also known as tóngyīn tōngyòngzi 同音通用字) for the word hè 鶴 (EMC: rak, LMC: xhak) (Pulleyblank 1991, pp. 122-23), with shuǐè 水鶴 referring to a species of crane. ${ }^{142}$ The relative frequency of related and unambiguous polysyllabic terms such as 水潦涸 (F: 10), 水澇涸 (F: 2) or 水老涸 (F: 2) (EMC: 6wi'law'rak; LMC: syj'law(')xhak) (Pulleyblank 1991, pp. 290, $184,122)$ suggests that the borrowing was, by the time, intentional, perhaps for the purpose of simplification or by custom. This phonetic loan is further attested, for example, in the praise verse composed by Wéndèng in his QFS for the 27th patriarch of India Prajñātāra 般若多羅, ${ }^{143}$ a verse that was later appended to his entry in the second juàn of the ZTJ. ${ }^{144}$

Regarding the meaning of shuǐ̀è in Wéndèng's preface, the term refers to a narrative, manifestly popular among Chán circles, which is recounted in the ZTJ's entry for Ānanda 阿難, the presumed second patriarch of India, in the following passage of juàn $1:^{145}$

師巡遊往至一竹林之間, 聞一比丘錯念佛偈曰:「若人生百歲, 不見水潦涸。 不如生一日, 而得睹見之。」阿難聞已, 嗟歎曰:「世間一凡有, 不解諸佛意。 徒載四圍陀, 不如空身睡。」阿難歎已, 語比丘曰:「此非佛語。如今當聽我 演佛偈曰:「若人生百歲, 不會諸佛機。未若生一日, 而得決了之。」」(具如 《寶林傳》所說也。 $)^{146}$

The Master (i.e., Ānanda) travelled around and arrived at a bamboo forest. [There] he heard a bhikṣu who was reciting erroneously a gātha of the Buddha, saying: "If a man lives one hundred years, but does not see the [white] crane, it would be better [for him] to live one day and see it." After hearing this, Ânanda lamented: "The common people of the world do not understand the intention of the buddhas. They vainly learn the four Vedas, but this does not compare to sleeping without any burden."147 After Ānanda had sighed, he said to the bhikșu: "These are not the words of the Buddha. You should now listen to me expound the gāth $\bar{a}$ of the Buddha: 'If a man lives one hundred years, but does not understand the key point of the Buddha, it would be better [for him] to live one day and apprehend it fully."' (This is completely like what is recounted in the Băolín zhuàn).

Beyond the reference to the $B L Z{ }_{1}^{148}$ in Chinese Buddhist literature, the earliest extant witness of this narrative appears to be in juàn 4 of the Âyùwáng zhuàn 阿育王傳 (Biography of King Aśoka; T50, no. 2042) ${ }_{1}^{149}$ where the confusion occurs between the terms shuĭlăohè 水老鶴 and shēngmiè fă 生滅法 (lit. "the law of arising and ceasing"). ${ }^{150}$ As is made more explicit in the Äyùwáng zhuàn, the passage recited erroneously by the monk originates from a stanza of the Dharmapada (“[ ... ] 誦法句偈”). In the Khuddaka Nikâya (Minor Collection) of the Pāli Canon, the stanza reads as follows: "Rather 
than living a hundred years, not seeing the arising and ceasing [of phenomena], better to live one day, seeing the arising and ceasing." 151 Since the confusion alluded to in the ZTJ or the Âyùwáng zhuàn cannot be explained through the phonological profiles of the terms in Middle Chinese, it can be surmised that it was inherited from a Middle Indic language. As a matter of fact, Kenneth R. Norman, in A Philological Approach to Buddhism, briefly mentioned this narrative in his discussion of Sanskritizations from Gāndhārī, noting that: "[t]his Chinese version [of the Aśokāvadāna] was obviously following a tradition based upon a Sanskrit form *udaka-baka, which could only come from a Gāndhārī-type dialect which inserted a non-historic - $k$ - in place of a glide $-y-$, in the compound udaya-vyaya 'arising and passing away'."152 In his edition of the Gāndhārī Dharmapada, John Brough had also mentioned this episode and reached a similar conclusion, although not necessarily through a Sanskrit translation of a Prakrit text. ${ }^{153}$ While the above explains the supposed phonetic origin of the monk's confusion, it is relatively unlikely that Wéndèng was aware of this and, therefore, the moral and sense of the story for him should probably be sought elsewhere.

In fact, in the $B L Z$, or at least in the version of the Shèngzhòu ji 聖䡒集 used to restore the text of the extant $B L Z$, the narrative continues. ${ }^{154}$ The bhikșu returns to see his master and recounts his encounter with Ānanda, informing him of the correct $g \bar{a} t h \bar{a}$. Upon this, the master retorts that Ānanda is old, that his memory is faulty, his wisdom deteriorating, his words replete with mistakes and that, therefore, he should not follow him. Shortly after, Ānanda crosses again the path of the bhikșu, who, against his expectations, is still reciting the erroneous verse. Interrogated about this, the latter explains that his master told him not to give in, thereby plunging Ânanda into a state of relative hopelessness and precipitating his will to enter into nirvāna.

In light of this more complete account of the story, more or less in line with that of the Ayùwang zhuàn, ${ }^{155}$ the focus appears to be less on the erroneous recitation of the $g \bar{a} t h \bar{a}$ than on the original misunderstanding of the bhikșu and his master, their incapacity to recognize their mistake, and, therefore, their inability to uphold the "correct teachings" of the Buddha. In fact, the term shuilăohè is commonly glossed in this way in modern dictionaries. ${ }^{156}$ In Wéndèng's preface, then, the expression "[cases of] shuihè easily arise" likely refers to similar phenomena, perhaps conceived in relation to the orality of transmission. This interpretation seems to be supported by the contrast offered in the following phrase, which points to issues of written textual transmission.

Indeed, as evidenced by the next clause (wū mă nán biàn 烏馬難辯), the second concern of Wéndèng relates to errors resulting from graphic confusions. In fact, this idiomatic expression appears to have gained wide currency from at least the Sòng dynasty onwards. In the CBETA (Chinese Buddhist Electronic Text Association 2021) collection of texts, several variants of the expression can be found, including “字經三 寫烏焉成馬” (F: 91), “三寫烏焉成馬” (F: 4), “烏焉成馬” (F: 41), “三寫烏成馬” (F: 1), “烏 焉成馬之誤” (F: 1), “寫烏成馬” (F: 7), and “三寫烏馬” (F: 1), which all share the same basic meaning: "Copying three times [the character] $w \bar{u}$ 烏 ('crow') turns it into a mă 馬 ('horse')", sometimes with an additional reference to the character yān 焉. The expression above indicates that confusions between these characters occurred relatively frequently during the copying process of manuscripts and this is understandable considering their cursive script forms. ${ }^{157}$ In fact, in the Goryeo edition of the ZTJ itself, certain demotic forms of $\mathrm{g}_{\text {and }}$ 焉, and the standard character form of 馬 could even be confused in their regular script forms (see Table 2 below). Naturally, as is amply evidenced by the manuscripts retrieved from Dūnhuáng, graphic mistakes were a common phenomenon and one of the causes of textual corruption. Ironically, such mistakes are well attested in the Dūnhuáng copy of Wéndèng's QFS (S.1635) and the verses of the QFS that were appended to the ZTJ. ${ }^{158}$ 
Table 2. Examples of the characters $w \bar{u}$ 烏, yān 焉, and mă 馬 in the Goryeo edition of the ZTJ.

\begin{tabular}{lcc}
\hline ZTJ_005-14.05.12 & ZTJ_004-04.28.07 & ZTJ_004-04.15.02 \\
\hline & & \\
\hline
\end{tabular}

It is worth noting that the terms shuǐhe 水涸 and wūmă 烏馬 succeed each other in the Zǔting shìuàn 祖庭事苑 (X64, no. 1261; edited by Mù'ān Shànqīng 睦庵善卿 in 1108; hereafter ZTSY), a Northern Sòng glossary of Chán terms. Indeed, in juàn 6, the author of the ZTSY notes “水涸: 音鶴。” (lit. “水涸: the sound is [like that of] 鶴"), and then purportedly cites the story of Ānanda and the bhikṣu as recorded in the Gēnběn shuō yĩqiè yǒubù pínàiyé záshì 根本說一切有部毘奈耶雜事 (T24, no. 1451; translated by Yì Jìng 義淨). Interestingly, however, the narrative is abridged and a short phrase is inserted in the beginning, mentioning that the name of the monk was Shuǐlăohè 水老鶴. ${ }^{159}$ Directly following the entry on shuǐhè, the ZTSY records: “烏 馬, 古語云: 三寫鳥成馬。” (lit. “Wūmă, an old adage says: 'Copying three times [the character] 烏 turns it into a 馬”'). ${ }^{160}$ According to Huang Yi-hsun 黃繹勳, the sources of the ZTSY come for the most part from materials related to the Yúnmén 雲門, Făyăn 法眼, and Línjì 臨濟 branches (see Huang 2006, pp. 140-41). Therefore, further research would be necessary to determine if the successive explanation of shuih̀ and wūmă should be attributed to the ZTSY's organizational scheme, to the specific relation between these two terms, or even if this could somehow be linked to the ZTJ or related sources.

Returning to the main point, the contrast offered between these two idiomatic expressions in Wéndèng's preface is probably not coincidental. From the above, it would appear that the first (shuihè yì sheng) refers to issues pertaining to the oral transmission of the teachings, while the second (wū mă nán biàn) points to common issues in written textual transmission. Both expressions highlight the need to record and collect the teachings of the Chán patriarchs and masters.

In this regard, it should be noted that while the Huìchāng 會昌 persecution and the Huángcháo 黃巢 rebellion had, to some extent, spared or even benefitted Chán Buddhist circles in the southeastern regions (see, e.g., Clark 1991, p. 60; Foulk 1992, pp. 25-27; Wáng 1997, pp. 53-63; Brose 2015, pp. 26-29, 30-31, and 53-67), the destruction of monasteries, stupas, and patriarchal halls throughout the country was probably still in the collective memory of certain communities. ${ }^{161}$ Following the death of Wáng Shěnzhī in 925, the Mĩn kingdom itself, and particularly Quánzhōu prefecture, went through an era of great political instability. ${ }^{162}$ The above, combined with the consolidation of Chán as a self-conscious movement (see, e.g., Foulk 1992, p. 27), may have raised the alertness of certain individuals to the importance of preserving this shared tradition and presenting Chán as a unified movement despite the proliferation of different lineages. The relative peaceful governance of Quánzhōu prefecture by Liú Cóngxiào and his support perhaps allowed for such an enterprise to materialize (see Suzuki 1975, p. 112; Clark 1991, p. 42; Wáng 1997, pp. 160-64). In this respect, it can be assumed without too much suspicion that the concerns expressed by Wéndèng in his preface were genuine and not a mere façade to justify the compilation of a text that would exclusively serve sectarian agendas.

\subsection{Wéndèng's Perception of the ZTJ}

In the last section of his preface, Wéndèng shares his impression upon receiving and reading the ZTJ, therefore providing us with precious (but little) information on how he regarded the initial compilation of Jing and Yún. 
First, the abbot of the Zhāoqing monastery associates the work with "pearls and jade gemstones stringed in a chain" (zhūyù liánhuán 珠玉聯環). This expression, beyond its function as a celebration of the literary quality of Jìng and Yún's compilation (Kinugawa 1998, p. 116; HYDCD 1986-1996, vol. 4, p. 546, no. 3), is likely used as a metaphor for the Chán patriarchs (and masters?) who succeed each other in the text, placing emphasis on their value both as individuals embodying and exemplifying the dharma ("the pearls and jade gemstones") and as a community ("stringed in a chain").

Second, Wéndèng indicates that the work compiled by Jing and Yún was rich in content (juănshū hàohàn 卷舒浩瀚). Indeed, as mentioned in the translation, this clause should probably not be understood literally, as pointing to the fact that the scroll of the ZTJ was particularly long. ${ }^{163}$ Rather, considering the parallelism with zhüyù liánhuán, it was likely intended in a metaphorical sense, with juănshü referring to the ZTJ itself and the stative-verb hàohàn, used figuratively to describe the richness or profundity of the volume's content. In fact, the use of metaphorical expressions is continued in the following phrase (jì dé fèng wèi 既得奉味), where the ZTJ is associated with the common noun wèi (lit. "savor; flavor, taste"), ${ }^{164}$ a term that is also used to refer to the purport or intent of a work (yìì 意義, zhĭqù 旨趣), ${ }^{165}$ in connection to its interest and literary flavor (yìwèi 意味). ${ }^{166}$

Having received the opportunity to taste the purport of the materials collected in the ZTJ, the abbot of the Zhāoqing monastery reportedly felt that his mind was refreshed (dàn jué shén qìng 但覺神清). Naturally, for Wéndèng, the ZTJ was not merely a piece of enjoyable literature or a work that had satisfactorily fulfilled some obscure sectarian agendas. As a collection of the gist of the teachings of figures associated with the Chán tradition (gưjīn zhüfāng făyào 古今諸方法要), Jìng and Yún's recent compilation was conceived as a religious text to be treated with great respect (ji dé fèng wèi). After all, the ZTJ re-enacted the verbal exchanges between the Chán masters, their disciples, officials, and other individuals, some of which had presumably led one party to gain a deeper insight into the Chán Buddhist truth-claims or triggered a so-called "enlightenment" experience.

While it is not surprising to find such appraisals and claims in the words of Wéndèng since he is himself part of that community of memory, it would be regrettable to neglect the self-narration and the ideological framework of the socio-religious actors of the time. ${ }^{167}$

\section{Concluding Remarks}

Throughout this study, we have demonstrated that the preface of Wéndèng, despite its relative brevity, not only provides a wealth of information on the circumstances and incentives that have led to the compilation of the ZTJ, but also informs us about the form and contents of the original text. In addition, the preface illustrates rather well the complexity of the ZTJ, both from the point of view of philology (e.g., variant characters, phonetic loans, intertextuality) and that of literary history (e.g., interplay of multifarious socio-religious motives, literary impetus). In the paragraphs that follow, we summarize some of the most important issues raised in this study.

First, concerning textual history, Wéndèng's preface informs us that the original ZTJ, as initially compiled by Jìng and Yún, consisted of only one scroll. This format, as we have seen, is confirmed by the opening line of the Goryeo preface, the Chóngwén zŏngmì, and the Tōngzhì. However, it also stands in contrast with the received Goryeo edition, which consists of twenty juàn. In this respect, an important contribution was made by Kinugawa, clarifying that the compilation and editing process of the ZTJ underwent at least three stages: (1) a version in one scroll collected by Jing and Yún around the mid-10th century, possibly ca. 952; (2) an expanded version in ten scrolls, perhaps completed by the end of the 10th century; and (3) the Goryeo edition of the ZTJ, edited and carved in 1245 (Kinugawa 1998, p. 122; Kinugawa 2010b, pp. 
313(4)-12(5)). Given Kinugawa's publication in 1998, we therefore know that it is inappropriate to equate the initial ZTJ prefaced by Wéndèng with the extant text.

Regarding the date of the initial compilation by Jing and Yún, it can be surmised that it must have approximately coincided with the request addressed to Wéndèng to write a preface. Combining information gathered from the header of the preface, Wéndèng's entry in the ZTJ, and other historical sources, we were able to determine that the composition of the preface must have been achieved after its author was conferred the dharma-name Jìngxiū by Liú Cóngxiào, i.e., probably after 949. In addition, six passages in the first and second juàn of the ZTJ identify the "present" as the tenth year of the Băodà era (952). As a result, it can be assumed with relative confidence that the ZTJ, as initially compiled by Jing and Yún, was completed around 952 or, at least, the mid-tenth century (see Kinugawa 2007, p. 945).

As for the contents of this initial compilation, the passages mentioned above indicate that at least sections of the received entries of Sākyamuni, Bodhidharma, Huìkě, Sēngcàn, Hóngrěn, Huìnéng, and probably Dàoxìn must be identical to Jìng and Yún's collection. ${ }^{168}$ Apart from this, other attempts at defining the contents of the original ZTJ remain hypotheses and should be treated with great caution. For instance, Kinugawa has argued that the ZTJ in one scroll more or less corresponds to the first two fascicles of the Goryeo edition, ${ }^{169}$ which would indicate that the text ended with the entry of Huinéng. While coherent from an editorial point of view, this hypothesis also raises a number of questions. For instance, if the ZTJ was effectively achieved when Wéndèng wrote a preface for it, one may wonder why materials on Chán masters such as Xíngsī, Huáiràng, Huìzhōng, Shítóu, and Măzŭ, all appearing in the $B L Z$ and the QFS, would have been omitted by the compilers. What would be the significance of such a text in the literary landscape of Chán histories and records? And how should one understand the expression gŭjīn zhüfāng făyào used by Wéndèng in his description of the ZTJ?

With the exception of fortuitous discoveries of manuscripts, only careful and methodologically sound research on the linguistic features of the text (e.g., interrogatives, verbal suffixes) and other textual aspects (e.g., toponyms, sources) could potentially enhance our understanding of the different strata that compose the ZTJ.

With regard to the incentives that have led to the ZTJ's compilation, the information that we can gather from the preface is relatively scant.

First, Wéndèng mentions that in spite of the fact that the "oral teachings" of the Chán masters circulated widely, likely through a written medium, a proper arrangement had not yet been set up with regard to the master to disciple transmission. Whether we interpret this as a claim concerning the absence of an established record of lineages or as a statement regarding the organization of written records of the teachings of the Chán masters, this assertion is at odds with what we know of earlier Chán histories such as the Léngqié shīzì jì, the Chuán făbăo jì, the Lidài făbăo jì, and the BLZ. In this regard, we know from the preface of the QFS and the first two juàn of the ZTJ that Wéndèng was at least familiar with the $B L Z$, which, as far as we can tell from the extant sources, recorded the lines of transmission of the Chán masters and arranged its contents according to this principle. In addition, since both his QFS and the ZTJ adopt the sequence of the thirty-three patriarchs of the BLZ (see, e.g., Yampolsky 2012, p. 9; Yáng 2006b, pp. 468-69), this would seem to indicate that if the abbot of the Zhāoqing monastery was left with a sense of dissatisfaction, it must have been related to Chán masters who did not have the status of patriarch. If correct, this would suggest that the ZTJ was intended as a more ecumenical work than previous Chán histories. However, this would challenge Kinugawa's hypothesis that the original text centered on the thirty-three patriarchs.

Building on this, Wéndèng specifically mentions two issues that were sources of concern to him: (a) errors related to the (oral) transmission of the teachings (shuihe yì shēng) and (b) graphic confusions in written records (wū mă nán biàn). The former 
probably resonates with the need felt by certain Chán communities to collect and record the teachings of the masters in this period of civil disturbances (see McRae 2000, pp. 51-52). As for the latter, we know from the large corpus of Dūnhuáng manuscripts of the 9th and 10th centuries that graphic errors were a frequent textual phenomenon. The recent compilation of Jìng and Yún, then, must have been regarded by the abbot of the Zhāoqing monastery as a remedy to his concerns.

Apart from this, the preface does not provide further details on the incentives behind the compilation of the ZTJ. ${ }^{170}$ It should be noted that in the third volume of his Sodōshū sakuin 祖堂集索引 (An Index to the Zǔtáng jí), Yanagida suggested that the ZTJ was specifically compiled at the request of Lǐ Jing, second ruler of the Southern Táng, at the occasion of the Xīnhài 辛亥 year (951). ${ }^{171}$ However, there is little textual evidence to confirm this hypothesis, ${ }^{172}$ and it would be at odds with what we know of the publication process of the $J D C D L$, although the political contexts are certainly different. ${ }^{173}$

In the final analysis, when read carefully, Wéndèng's preface illustrates well the interplay of religious, socio-political, literary, and linguistic phenomena that have shaped the ZTJ's compilation. In this respect, it is the authors' wish that various angles of study (e.g., history, philology, socio-anthropology, religious studies) should be integrated and complement each other in order to work toward a rigorous reconstruction of the complex historical web that gave rise to the literary genre to which the ZTJ belongs. In this regard, we are very much indebted to the legacy of Yanagida Seizan, who strived to find a balance between the conceded mythological self-narration of Chán socio-religious actors and the kind of hyper-historicism that is occasionally found in academia. ${ }^{174}$

Author Contributions: Conceptualization, L.V.C. and C.A.; methodology, L.V.C. and C.A., investigation, L.V.C.; writing—original draft preparation, L.V.C.; writing—review and editing, L.V.C. and C.A.; funding acquisition, L.V.C. and C.A. All authors have read and agreed to the published version of the manuscript.

Funding: This research was funded by the Bijzonder Onderzoeksfonds (Special Research Fund) of the Universiteit Gent (Ghent University), 01D35717, and the Chiang Ching-kuo Foundation for International Scholarly Exchange 蔣經國國際學術交流基金會, DD010-U-20.

Data Availability Statement: Not applicable.

Acknowledgments: We would like to express our gratitude to the Library of the Institute for Research in Humanities 人文科学研究所図書室 of Kyōto University 京都大學 (Kyōto, Japan) and to Christian Wittern (Kyōto University) for the authorization to use scans and photographs of the print of the Zǔtáng jí 祖堂集. In addition, we extend our thanks to Marcus Bingenheimer (Temple University) for his guidance in the initial stages of the TEI mark-up and for kindly providing the original XSLT file which facilitated the production of various TEI-based editions of the Zútáng jí and related manuscripts. Eventually, we would like to thank Bart Dessein (Ghent University), Wú Lúchūn 吳盧 春 (Zhèjiāng Provincial Museum 浙江省博物館), and the anonymous reviewers at Religions for their comments and offering suggestions for improvement.

Conflicts of Interest: The authors declare no conflict of interest. The funders had no role in the design of the study; in the collection, analyses, or interpretation of data; in the writing of the manuscript, or in the decision to publish the results. 


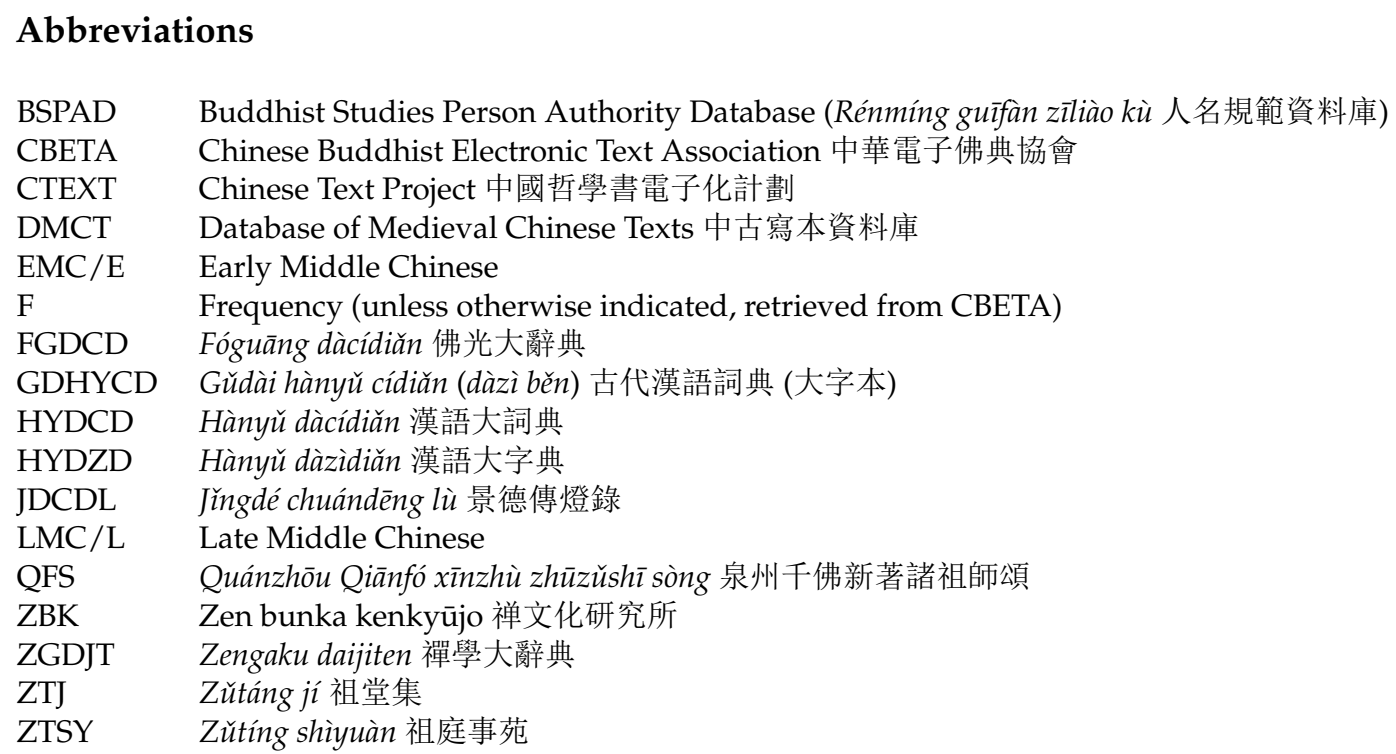

\section{Notes}

1 The ZTJ is variously classified as the earliest example in the chuándēng lù genre, often abbreviated as dēnglù 燈錄 (lamp records) or dēngsh chánzōng sȟ̌shū 禪宗史書 (Chán histories) (see, e.g., Yanagida 1980-1984, vol. 1, p. 1; Yáng 2001, p. 1). Taken in its broadest sense, the term dēnglù includes works such as the Chuán făbăo jì 傳法寶紀 (Record of the Transmission of the Dharma Jezwel; composed by Dù Fěi 杜朏 probably between 716 and ca. 732; e.g., P.3664/3559, P.2634), the Léngqié shīzi jì 楞伽師資記 (Record of the Masters and Disciples of the Lañkā[vatāra]; composed by Jìngjué 淨覺 perhaps between 713 and 716, or in the early 8th c.; e.g., P.3436, S.2054), and the Lidài făbăo jì 歷代法寶記 (Record of the Dharma Jewel Through the Generations; composed between 774 and 780; e.g., S.516, P.2125) (see, e.g., Tanaka and Chéng 2008). In the narrowest sense, however, dènglù refers specifically to multi-branched Chán transmission records as exemplified by the Jǐngdé chuándēng lì 景德傳燈錄 (Jǐngdé [era] Record of the Transmission of the Lamp; T51, no. 2076; compiled by Dàoyuán 道原 ca. 1004, edited by Yáng Yì 楊億 et al. by 1009). With regard to the ZTJ, Kinugawa Kenji 衣 川賢次 is probably the most cautious in the terminology that he uses, introducing the text as the earliest fully extant lamp history of the Southern Chán school (“現存最早一部完整的南宗禪燈史”; Kinugawa 2007, p. 934; see also Kinugawa 2010b, p. 316).

2 The dates provided for the Chán patriarchs and masters in this paper are, for the vast majority, traditional dates referenced in Chán histories and Buddhist gazetteers. These should be taken as indicative rather than historically reliable dates.

3 (Yáng 2006b, p. 477). On Xuěfēng Yìcún and his disciples, see, e.g., (Welter 2006, pp. 90-110; Brose 2015, pp. 50-62, 143-45).

4 The BLZ is also known under the titles Dà Táng Sháozhōu Shuāngfēngshān Cáoxī Băolín zhuàn 大唐韶州雙峰山曹溪寶林傳 or Shuāngfēngshān Cáohóuxī Băolín zhuàn 雙峰山曹侯溪寶林傳. The text is traditionally attributed to a certain Zhijù 智炬 (or Huìjù 慧 炬) and the likely fictitious Tripitaka Master Shèngchí 勝持 (d.u.). Originally preceded by a preface of the poet-monk Língchè 靈 澈 (746-816), now lost, the BLZ was supposedly completed in the 17th year of the Zhēnyuán 貞元 era of the Táng 唐 (801) (Shiina 1980, p. 234; Yáng 2006b, p. 461). On the BLZ's debated authorship and composition date, see, e.g., (Jorgensen 2005, pp. 644-49) and (Jia 2006, pp. 84-89; cf. Jiă 2011). For an overview of the BLZ, see (Yáng 2006b, pp. 461-75), to be read in conjunction with ( Jorgensen 2005, pp. 640-51) and (Jiă 2011). The ten juàn BLZ survives mostly through the Shōren-in 青蓮院 manuscript edition (juàn 6) and the Jinzzàng 金藏 woodblock edition (juàn 1 to 5 , and 8 , with missing sections). In addition, quotations from the BLZ, sometimes with reference to the juàn from which the passages were cited, can be found in texts such as the Yìchŭ liùtie e 義楚六帖, the Zǔting shìuàn 祖庭事苑 (see Section 4.2), or the Keitoku dentō shōroku 景德傳燈抄錄 (on this topic and these texts, see Shiina 1980; Shiina 2000; see also Section 4.1).

5 The date commonly encountered in the secondary literature is the 10th year of the Băodà 保大 era of the Southern Táng 南唐, i.e., 952 (see, e.g., Yanagida 1980-1984, vol. 3, pp. 1579, 1584). This is discussed in Section 4.1.

6 On the Goryeo Daejanggyeong, see the introduction to Section 2.

7 (Kinugawa 1998, p. 113; 2007, p. 937). Note that in the ZTJ, Gwangjun is originally written with a graph (A00160-004; Jiàoyùbù yìtǐzì zìdiăn 2017) that is close to 㑺 (A00160-001; cf. image provided in the TEI edition and the variants module of the Database of Medieval Chinese Texts; see below), variant of 儶 (A00160-002; see also A00160-005), itself variously conceived in historical lexicographical sources as a standard character or a graphic variant of 俊. We follow the conventions of previous scholars and use Gwangjun 匡售 (see, e.g., Yáng 2006b, p. 483; Kinugawa 2007, p. 945).

8 For a brief discussion of some of these terms, see (Anderl 2012, pp. 49-53) and (Welter 2008, pp. 60-63). The editorial notes are

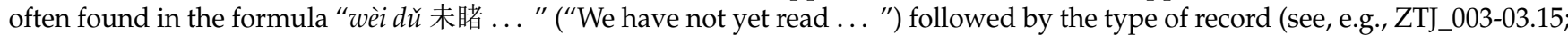
Zen bunka kenkyūjo 1994, p. 104; hereafter ZBK). In addition to the terms mentioned, there are two references to yǔběn 語本 (lit. “book of sayings") in the entries of Dōngsì Rúhuì 東寺如會 (744-823) (ZTJ_015-09.04; ZBK, p. 569) and Yăngshān Huijì 仰山慧寂 
(807-883) (ZTJ_018-19.28; ZBK, p. 693). The term yǔlù 語錄 ("record of sayings"), however, does not appear in the text (on this topic, see, e.g., Yanagida 1985; Wittern 1998, pp. 51-67; Welter 2008, pp. 64-72; Anderl 2012, pp. 56-58). Eventually, it should be noted that, with a few exceptions, most of the sources used for the compilation of the ZTJ's entries on Chinese Chán masters have not survived the vicissitudes of time.

9 (Yanagida 1980-1984, vol. 3, pp. 1585-88). The BLZ is explicitely mentioned nine times in the first two juàn 卷, usually with the formula “jù rú 'Băolín zhuàn' (suǒ shuō) yě 具如《寶林傳》(所說) 也。” (lit. “Completely like (it is stated in) the Băolín zhuàn") (see, e.g., ZTJ_001-17.27; ZBK, p. 34). This is sometimes abbreviated to jù rú zhuàn zhōng 具如傳中 (F: 5; e.g., ZTJ_001-21.01; ZBK, p. 41) or jù rú běn zhuàn 具如本傳 (F: 5; e.g., ZTJ_001-21.24; ZBK, p. 42). On the QFS, see Section 3.2.

10 This includes poems that have apparently only survived in the ZTJ, e.g., of Bái Xíngjiăn 白行簡 (776-826), the younger brother of Bái Jūyì 白居易 (772-846) (ZTJ_003-04.06 to ZTJ_003-04.08; ZBK, p. 105; see Sūn et al. 2007, p. 146, n. 2). See also (Demiéville 1970, pp. 264-65).

11 There are at least twenty references to beizwén 碑文 ("stele inscription") across the text, two to bēiming 碑銘 (roughly synonymous with bēiwén), and one to tăming 塔銘 ("stūpa inscription") (approximations retrieved from Chinese Buddhist Electronic Text Association 2021). Interestingly, one bēiwén is referred to as the Xiāngzhōu Yánqìngsì zǔshìtáng shuāngshēng bēiwén 裹州延慶寺祖師 堂雙聲碑文 (ZTJ_019-09.08 to 09; ZBK, ), with a rp. 717eference to the patriarchal hall (zǔshītáng 祖師堂).

12 For example, an excerpt in the fifth textual unit of Niútóu Făróng's 牛頭法融 (594-657) entry can be traced back to a passage of the Juéguān lùn 絕觀論 (e.g., P.2732, P.2047, P.2045) (see Yanagida 1980-1984, vol. 1, pp. 1-2; Sūn et al. 2007, pp. 137, 141); parts of Huìnéng's 慧能 (638-713) entry appear to come from the Cáoxī dàshī zhuàn 曹溪大師傳 (Biography of Great Master Cáoxī; X86, no. 1598; ca. 781; see, e.g., Jorgensen 2005, p. 655; Sūn et al. 2007, pp. 133-34), although perhaps through the BLZ (Shiina 1980, p. 252); in addition, it is possible that the compilers made use of lost records such as the Nányuè gāosēng zhuàn 南获高僧傳 (Biographies of Eminent Monks of Nányuè) or the Xù Băolín zhuàn 續寶林傳 (Continued Chronicle of the Băolín [Monastery]) in four juàn, both compiled by Wéijìng 惟勁 (fl. 907) in the beginning of the 10th century (Yanagida 1980-1984, vol. 3, p. 1586; see also Jorgensen 2005, pp. 744-46). The latter is mentioned, among other texts, in Wéijing's entry in the ZTJ (ZTJ_011-14.20; ZBK, p. 439; Sūn et al. 2007, p. 528). However, unlike the BLZ, his records are not explicitly quoted in the ZTJ.

13 (Kinugawa 2007, p. 938; 1998, p. 118). A good example is the common use of the interrogative shénmó 什摩 (F: 1052; throughout the 20 juàn) or the less frequent 甚摩 (F: 8), both gradually replaced by 什麼/甚麼 in the early Sòng. On this topic, see, e.g., ( Kinugawa 1998, p. 118; Anderl 2017, p. 690).

14 The Database of Medieval Chinese Texts (see Anderl 2021; hereafter DMCT) is a collaborative project of Ghent University and the Dharma Drum Institute of Liberal Arts 法鼓文理學院. For an overview of the functions of the database, see (Anderl 2020). The editions available on the DMCT are XML-based scholarly digital editions of primary sources that follow the TEI (Text Encoding Initiative) P5 Guidelines, with adaptations. The editions of the prefaces of Jingxiū and Gwangjun are annotated, with an emphasis on philological aspects (e.g., variant characters, phonetic loans, graphic mistakes) (see Van Cutsem 2020a, 2020b). As a special feature of the diplomatic editions, images of variant characters (e.g., demotic characters, simplified characters, archaic forms) from the print of the ZTJ stored at Kyōto University (see below) are made available. We express our gratitude to the Library of the Institute for Research in Humanities 人文科学研究所図書室 of Kyōto University for the authorization to use these images and to Christian Wittern (Institute for Research in Humanities, Kyōto University) who facilitated the operation. In addition, we would like to thank Marcus Bingenheimer (Temple University) for the invaluable help that he provided to Laurent Van Cutsem in the beginning stage of the TEI editing process.

15 ZTJ_001-25.12; ZBK, p. 49; (Sūn et al. 2007, p. 60). See Figure 1. On the term dūjiàn 都監. (“Director-in-chief; directorate”), see (Hucker 1985, pp. 536-37, no. 7192) and (HYDCD 1986-1996, vol. 10, p. 640). Paul Demiéville (1894-1979) translated with “contrôleur général spécialement affecté au Grand Pițaka" (Demiéville 1970, p. 262). See also (Yanagida 1980-1984, vol. 3, p. 1597).

16 Retrieved from the Buddhist Studies Time Authority Database (see Fóxué míngxiāng guīàn zīliàokù jiànzhì jìhuà 2021b, accessed on 1 April 2021).

17 The Palman Daejanggyeong supposedly counts, in total, 81,258 plates (Lancaster and Park 1979; Sungahn 2011, p. 71). On the different appellations of the second Goryeo canon, see (Sungahn 2011, pp. 70-71). For a brief overview of the history of the Korean Buddhist canons, see (Lancaster and Park 1979; Wu and Dziwenka 2015; Sungahn 2011).

18 The works belonging to what is sometimes referred to as the zábăn 雜版 (“miscellaneous plates") or zàngwài 藏外 (“extracanonical") section of the Goryeo canon are contrasted against those of the yuánzàng 原藏 (“original canon”) or zhèngzàng 正藏 (“orthodox canon") section, which corresponds to the works listed in the Dàzàng mùlù 大藏目錄 (K. 1405) (Baba 2004, pp. 678-79; Sungahn 2011, p. 71). The section to which the ZTJ belongs is also known as the bǔyí băn 補遺板 ("supplementary plates"), probably in connection to the Dàzàngjīng bǔyi mùlù 大藏經補遺目錄 (K. 1514; cf. Lancaster and Park 1979, p. 481), a short catalog written by Haemyeong Jangung 海冥壯雄 (d.u.) in the second year of the Gojong 高宗 era of the Joseon 朝鮮 (1865), that lists 15 works absent from the Dàzàng mùlù (Baba 2004, p. 679; Sungahn 2011, p. 71; Kinugawa 2007, p. 934). The ZTJ (“祖堂集二十卷”) is the fifth work referenced in the catalog of Haemyeong Jangung.

19 (Lancaster and Park 1979; Wu and Dziwenka 2015, pp. 251-52, 254). This is gathered from a passage of the Goryeo sa 高麗史, gwon 卷 24 (sinhae 辛亥 year, ninth month 九月) (see Kokusho Kankōkai 1908-1909, vol. 1, p. 360; Sungahn 2011, p. 73). For an overview of the historical circumstances and a discussion of the incentives that led to the production of the second Goryeo canon, see (Wu and Dziwenka 2015).

For further details, see: (Sungahn 2011, pp. 74-75; Wu and Dziwenka 2015, p. 254; Yanagida 1980-1984, vol. 3, p. 1597). 
(Shiina 1984, pp. 232-33; Yanagida 1980-1984, vol. 3, p. 1597; Kinugawa 2007, pp. 933-34). According to Wáng Cuilíng 王翠玲, it is likely that the Zōngjing lù was compiled between 954 and 970 (Wáng 1999, p. 355). Alternative translations of the title include "Record of the Source-Mirror", "Record of the Mirror of the Axiom", "Record of the Mirror of Truth", and so forth.

Wu and Dziwenka (2015, p. 254), probably by inadvertence, write that the carving process began in 1247 . In fact, according to Ven. Sungahn, the works collected in the Dàzàng mùlù seem to have been carved between 1237 and 1248, while the texts listed in the Bǔyí băn mùlù were carved from 1243 to 1248 and from 1250 to 1251 (Sungahn 2011, p. 73).

(Kinugawa 2007, p. 933; Wu and Dziwenka 2015, p. 255). As noted by Wu and Dziwenka (2015, p. 279, n. 25), the circumstances of the transfer of the woodblocks to the Haein monastery are not entirely clear. In general, the dates encountered in the scholarly literature are 1398 or 1399 (e.g., Lancaster and Park 1979), which correspond to the first year of the reign of the second Joseon king Jeongjong 定宗 (1357-1419; r. 1398-1400). See also (Sungahn 2011, pp. 79-80). For further details, see: (Yanagida 1980-1984, vol. 3, p. 1579; Demiéville 1970, p. 262; Kinugawa 2007, p. 934).

These approximations were retrieved from the CBETA edition of the ZTJ (B25, no. 144). As can be seen from the editorial notes in the margins, which mention the juàn and the zhāng of the respective printing blocks, the two prefaces, including the list of patriarchs and masters (table of contents), are part of the first "physical" juàn. The first juàn per se, in terms of contents, begins on zhāng no. 4 (see ZTJ_001-04.08) and consists of ca. 10,630 characters. If we take into account this distinction, it is juàn 3 that is the second largest, with ca. 11,130 characters.

For purpose of comparison, the Goryeo edition of the Zōngjìng lì appears to have, on average, ca. 8,300 characters per juàn in its first twenty juàn (approximations retrieved from the CBETA edition, T48, no. 2016, i.e., without the yīnyì 音義 sections).

(Kinugawa 2007, p. 934). According to our calculations, the ZTJ was carved on 197 woodblocks (see Van Cutsem 2020c). While Kinugawa (2007, p. 934) indicates that the text was carved on 199 woodblocks, according to Jorgensen (2005, p. 2, n. 2), the original Japanese version of Kinugawa's paper mentioned a total of 197 printing blocks. Therefore, we suspect that a typographical error was made during the translation.

This corresponds to: “Zǔtáng [jí] 祖堂[集], [dì] wǔ [juàn] [第]五[卷], [dì] shíwǔ zhāng [第]十五丈(張), [dì] shíliù zhāng [第]十六丈(張)” (lit. "Printing surface no. 15 and printing surface no. 16 of the fifth fascicle of the Collection of the Patriarchal Hall").

Kinugawa (2007, p. 934) writes by inadvertence that each zhāng consists of 23 columns. This is the regular number of columns per zhāng in the zhèngzàng section of the Goryeo canon (as Kinugawa himself correctly points out). By contrast, the Zōngjìng lì usually has 30 columns per printing surface. Note that the pages of 14 lines that Albert Welter $(2008$, p. 60$)$ refers to are the result of modern binding techniques and are not related to the original woodblock edition of the ZTJ. Indeed, for practical reasons, the prints of the zhang were, in some cases, each folded in two and then bound together to form the volumes that are now stored, for example, at Hanazono University or Kyōto University (see Section 2.3). Therefore, in these editions, the first (half) page, which presents itself on the left-hand side (see, e.g., ZBK, p. 1), corresponds to the first half of the first zhāng of the first juàn. On the verso of this (half) page is the second half of the first zhāng of the first juàn. The third and fourth pages correspond, respectively, to the first and the second halves of the second zhäng of the first juàn (on the back of the first woodblock). Pages five and six correspond, respectively, to the first and second halves of the third zhang (on the front side of the second woodblock), and so forth. Generally speaking, the prints were folded after the fourteenth line (i.e., in half). However, this is not always the case. For example, zhāng no. 7 of the Jinbunken print (see below) is folded after the fifteenth line.

The reader may have noticed that in Figure 1, this inscription appears on the left-hand side of the image, which corresponds to the right-hand-side margin when printed. This is an exception that occasionally occurs on the last zhāng of a juàn. See, e.g., the last zhāng of juàn 8 and 14 (respectively, ZBK, pp. 334, 552).

According to Jorgensen and the source that he cites, most of them appear to have been members of the Goryeo court (Jorgensen 2005, p. 740).

ZTJ_001-02.29; ZBK, p. 4. The characters 仁甫 are written closely to each other and are not easy to interpret.

ZTJ_001-01.01 to ZTJ_001-01.12; ZBK, p. 1.

ZTJ_001-01.13 to ZTJ_001-04.07; ZBK, pp. 1-7.

For example, (Fóguāng dàzàngjīng biānxiū wěiyuánhuì 1994, p. 3; Wú and Gù 1996, p. 2; Zhāng 2009, p. 7). An alternative rendering is Hăidōng xīnkāi yìnbăn qiánjì 海東新開印版前記 (Foreword to the Korean newly edited printing blocks [of the Zǔtáng jí]) (see Zhāng 2001, p. 2; Xiàng 2005, p. 186). This appellation perhaps originates from the following passage at the end of Gwangjun's preface:「海東新開印版《祖堂集》[ . . . ]」 (ZTJ_001-04.06; ZBK, p. 7). Yanagida frequently refers to it with the term fùjì 附記 (lit. “appended notes"; see, e.g., Yanagida 1980-1984, vol. 3, p. 1597).

ZTJ_001-04.08; ZBK, p. 7.

ZTJ_002-01.07; ZBK, p. 50; (Sūn et al. 2007, p. 61).

ZTJ_005-01.01; ZBK, p. 182; (Sūn et al. 2007, p. 240). Note that juàn 4 opened with the entry of Shítóu Xīqiān 石頭希遷.

ZTJ_014-01.01. In the Zen bunka kenkyūjo facsimile (see below), the upper part of èr 二 is not visible and the character therefore looks like a $y \bar{\imath}$ - (ZBK, p. 514). Unfortunately, Sūn et al. (2007, p. 610) and Zhāng Měilán (Zhāng 2009, p. 357) did not notice 
this and both have “曹溪第一代法孫” in their editions. Zhāng Huá 張華 (Zhāng 2001, p. 465) ignores the editorial comment altogether. However, the note is correctly transcribed in the kundoku 訓読 edition of the ZTJ edited by Koga Hidehiko 古賀英彦 ( Koga 2003, p. 545). In the print stored at the Library of the Institute for Research in Humanities (see below), the upper part of 二 is faint but legible. In addition, considering that juàn 14 contains the entries of Măzŭ and eleven of his first-generation disciples, and that the editorial note reads “Jiāngxī xià 江西下", the second part should probably be corrected to 「[ ... ] 曹溪第三代法孫。」 ("third generation of the dharma-heirs of Cáoxī"; or at least "dì èr, sān dài 第二、三代").

See ZBK, p. 761.

See the .xlsx table and the penultimate note in (Van Cutsem 2020c).

This is according to the information provided on the website of the Institute for Research in Humanities: Jinbun kagaku kenkyūjo shōkai: enkaku 人文科学研究所紹介: 沿革 (https://www.zinbun.kyoto-u.ac.jp/about/history.html; accessed on 1 August 2021). For a short overview of a few of the prints, facsimiles, and modern editions of the ZTJ, see, e.g., (Kinugawa 2007, pp. 934-35). The reader is invited to consult the annotated TEI-based edition of the preface of Van Cutsem (2020a) published on the website of the Database of Medieval Chinese Texts.

Renderings of Wéndèng's preface in kundoku are available in: (Yanagida 1964, pp. 13-18; Ishii 1986, p. 168; Koga 2003, vol. 8, p. 1). However, with the exception of Yanagida, who provided well-researched notes and a relatively good modern Japanese translation, the value of these renderings remains limited. Translations by Kinugawa (2010b, pp. 315(2)-14(3) for Japanese; 2010a, pp. 8-9 for modern Chinese) correct some of the mistakes or imprecisions of Yanagida, but are not always close to the original text. In Western languages, the second half of the preface was translated into French by Paul Demiéville (1970, pp. 268-69). However, the first half of the preface was omitted and characterized as "des considérations générales d'une rhétorique intraduisible" (Demiéville 1970, p. 268). A tentative English translation of the whole preface can be found in (Anderl 2004, pp. 15-17). However, some passages had remained problematic or unsolved.

$Q \bar{u}$ 曲, “extensively, universally” (zhōubiàn 周遍, zhōuquán 周全, pǔbiàn 普遍; see HYDCD 1986-1996, vol. 5, p. 562, no. 7; HYDZD 2010, vol. 9, p. 1591, no. 8). Zhāng Měilán interprets qūshōu 曲收as “to accept, to receive universally” (“曲收, 普遍接受, 收容。 唐宋常用。”, Zhāng 2009, p. 5, n. 2). In his recent study on Chán lexicon and the Zǔtáng jí, Zhān Xùzuǒ 詹緒左 equally argues that $q \bar{u}$ in qu $\bar{u}$ sho $u$ has a meaning close or identical to the adverb zhōubiàn and that qu in qūshòu 曲授, often seen in the expression qūshò xuétú 曲授學徒 (lit. “to extensively teach apprentices"), shares the same meaning (Zhān 2018, pp. 234-35). Kinugawa ( 2010b, p. 315(2)) renders qūshōu with an equivalent to the English expression "to extend a helping hand".Míž 迷子, lit. "deluded son(s)", as in a well-known passage of the Jingāng sānmèi jīng 金剛三昧經 (see CBETA 2019.Q3, T09, no. 273, p. 369a1-5). More generally, the term refers to people who are said to be deluded because they fail to see things as they really are (see, e.g., FGDCD 1989, p. 4330). Alternatively, zi 子 could be understood as a suffix (Jiāng and Cáo 1997, p. 361, no. 3), with mízi being roughly equivalent to qúnmi 群迷, which appears, for example, in the praise verse composed for the eighth patriarch of India, listed in the QFS of Wéndèng:「佛陀難提，大化群迷。[ . . ] ] ("As for Buddhanandi, he greatly transformed the deluded ones. [ ... ]"; S.1635r_25; Van Cutsem 2021). In our translation, we use "deluded sons" since "sons" can adequately be interpreted literally or as a figurative plural form.

Lit. "before the tip of the blade has become visible yet". Note that a similar expression (“鋒鋩未兆已前”) is found in the entry of Luòpǔ 落浦 (835-898; BSPAD ID: A009348) (see ZTJ_009-01.24; ZBK, p. 337). Fēngmáng 鋒鋩 (also written 鋒芒), literally means "cutting edge; tip or sharp point [of a weapon]" (HYDCD 1986-1996, vol. 11, p. 1302, no. 1). Metaphorically, it refers to the "dashing spirit" or "talent" of a person (HYDCD 1986-1996, vol. 11, p. 1302, no. 4) or to the "sharpness, incisiveness" of words and speech (HYDCD 1986-1996, vol. 11, p. 1302, no. 6). The last option is the most likely when considered in parallel with jīju 機句, "pivotal phrases", in the following sentence (see below). The term is further related to jīfēng 機鋒, which refers to the presumed acute mindset or sharp demeanour of a Chán master who teaches through methods that may in appearance defy logic or be non-verbal (see FGDCD 1989, p. 6253; Nakamura 2001, p. 269d; ZGDJT 1985, p. 207b).

Xuánshū 玄樞, lit. "profound pivot", refers to the critical point, the gist of the Buddhist teachings (see HYDCD 1986-1996, vol. 2, p. 322, no. 2; ZGDJT 1985, p. 290a).Jī 機 (denominative adjective) "pivotal; critical; opportune; etc." (HYDZD 2010, vol. 3, pp. 1392-93; Kroll 2015, p. 181, no. 2; see also the voluminous entries in Mochizuki 1932-1936, pp. 491-93; Nakamura 2001, p. 250c; FGDCD 1989, p. 6249). The character is particularly frequent in Chán lexicon and can be used both as an adjective or a noun. Therefore, the jijju機句, "critical phrases", are the utterances of the "sages" that are said to trigger or provide a key for the listeners to gain an insight into the hereabove mentioned "mysterious essence" of the Buddhist teachings. Yanagida further connected the term to the expedient means (fängbiàn 方便) used by the Chán masters (see Yanagida 1964, p. 15).

In fěi shēng 罒生, shēng 生is most likely used as a noun referring to the sentient beings, which echoes lì shēng 利生 (“to benefit sentient beings"; see, e.g., Nakamura 2001, p. 1268b). Fěi 匪 (Baxter and Sagart 2014: pj+jX; Pulleyblank 1991, p. 93: L. fjyj ' /fji` ) is probably equivalent to $f \bar{e} i$ 非 (Baxter and Sagart 2014: pj+j; Pulleyblank 1991, p. 92: L. fjyj/fji), used here in the sense of méiyǒu 沒有 or wú 無 (“there is no”) (see, e.g., Bái and Chí 2004, p. 89; Wáng 1986, p. 396; Péi 1996, p. 876).

Ning 寧, here equivalent to q̌̌ 豈 (Wáng 2007, p. 287), is used as an adverb indicating a rhetorical question (Wáng et al. [1996] 1999 , p. 229; Wáng 1986, p. 190). Yanagida (1964, p. 17) interpreted this passage rather differently, probably misled by the complex syntactic structure of the sentence. Kinugawa's (2010b, p. 315(2)) translation, in contrast, is close to ours. This interpretation is supported by a passage in Zōngmì's 宗密 entry in juàn 6:「第六問曰:「諸經皆說度脫眾生，且『眾生即非眾生』，何故更勞度 脫?」師答曰:「眾生若是實, 度之即為勞。既自云『即非眾生』, 何不例度而無度? 」」 (ZTJ_006-05.05 to 07; ZBK, p. 226; Sūn et al. 2007, p. 289). Many thanks to Wú Lúchūn 吳盧春 (Zhèjiāng Provincial Museum 浙江省博物館) for pointing this out. 
In néngsuǒ 能所, néng 能refers to the agent of an action and suǒ 所 refers to the patient or the target of the action. The meaning of the two terms is linked to their syntactic function. The Fóguāng dàcídiăn 佛光大辭典 illustrates this through several examples: “例如能見物之「眼」, 稱為能見; 為眼所見之「物」, 稱為所見。 [ ... 修行者, 稱能行; 所行之內容, 稱所行。 [ ... ]” (“For instance, the 'eye' that can perceive things is referred to as néngjiàn (i.e., that which is capable of seeing); and the 'thing' that is perceived by the eye is referred to as suǒjiàn (i.e., what is seen)." [ . . . ] As for the practitioner, he is referred to as néngxíng (i.e., the one who is capable of practicing); and the content of what is being practiced is referred to as suoxxing (i.e., what is practiced). [ ... ]) (FGDCD 1989, p. 4296). For sources related to the term néngsuǒ, see, e.g., (Mochizuki 1932-1936, p. 4167b-c; ZGDJT 1985, p. 1006d; Nakamura 2001, p. 1340b). Interestingly, individuals who are qualified to teach and "transform" others are referred to as nénghuà 能化, a term that is usually ascribed to buddhas and bodhisattvas but also to teachers in general (FGDCD 1989, p. 4292; Nakamura 2001, p. 1338c (1)). In contrast, the recipients of the teachings, i.e., the sentient beings or the disciples, are referred to as suǒhuà 所化 (FGDCD 1989, p. 3244; Nakamura 2001, p. 916c (1, 2, 3)). These two terms help us to clarify the meaning of the preceding sentence in which the sages, in a deluded framework, would act as the agents, and the sentient beings as the patients. Yān 焉 can either be interpreted as an interrogative pronoun, “how?; in which way?" (Wáng 2000b, p. 657; GDHYCD 2003, p. 1805) or as an adverb indicating a rhetorical question (Zhōngguó shèhuì kēxuéyuàn yǔyán yánjiūsuǒ and Gǔdài hànyǔ yánjiūshì 1999, p. 673; Wáng 1986, p. 578).

56 The second part of the sentence could either be interpreted as a general claim concerning the absence of a system to record and establish the lines of transmission of the Chán masters or, more specifically, as a statement regarding the lack of a lineage-based arrangement of the Chán masters' teachings. Yanagida's (1964, p. 17) rendering appears to favor the second option. Demiéville has "L'enseignement par la parole est très répandu dans le monde, mais la filière n'en a pas encore été ordonnée selon la succession des maîtres" (Demiéville 1970, p. 268), where the word "filière" refers to the order of succession. Welter also offered a translation of this sentence: "The oral teachings [of Chan] (yanjiao 言教) have spread bountifully across the seas, but the way these are linked together (tiaoguan 條貫) has not been arranged in terms of [the relationships between] masters and their disciples" (Welter 2008, p. 57). Eventually, Kinugawa's translation, although slightly ambiguous, probably follows the second option as well (Kinugawa 2010b, p. 315(2); 2010a, p. 9). First, considering the parallel syntactic structure of the phrases, tiáoguàn 條貫 is likely used as a disyllabic noun, close to tiáoľ 條理 ("arrangement; order") or xitǒng 系統 ("system") (HYDCD 1986-1996, vol. 1, p. 1485; Wáng 2000a, p. 998; GDHYCD 2003, p. 1550). Second, all scholars mentioned above seem to agree on the fact that tiáoguàn should be understood in connection to yánjiào. Note that Yanagida and Welter explicitly interpret yánjiào as pointing to written records (see Yanagida 1985, pp. 234-36; Welter 2008, pp. 56, 85). This is discussed in Section 4.2.

57 The character 涸 is a phonetic loan for the word hè 鶴, “crane” (Pulleyblank 1991, pp. 122-23: L. xhak, E. vak), with shuihè 水鶴 referring to a species of crane (also known as shuĭlăohè 水潦鶴, etc.; see HYDCD 1986-1996, vol. 5, p. 890, and vol. 12, p. 1143; FGDCD 1989, p. 1487). Special thanks are due to Zēng Chén 曾辰 (Sìchuān University 四川大學 and Ghent University), who first pointed this out during a reading group session at Ghent University. In the ZTJ, this phonetic substitution is further attested, for example, in the polysyllabic term shuillăohè 水潦涸 (ZTJ_001-17.22.17) in the entry of Ānanda 阿難 (see ZBK, p. 34; Sūn et al. 2007， p. 26). For other occurrences of the term, see (Zhān 2018, pp. 103-4). The term is connected to a popular narrative according to which a monk is reciting erroneously a putative $g \bar{a} t h \bar{a}$ of the Buddha. Having been corrected by Ānanda, the monk nonetheless follows the instructions of his own master and continues to recite the erroneous $g \bar{a} t h \bar{a}$. As such, the term likely points to issues pertaining to the oral transmission of the teachings and mistakes that endanger the transmission of the "correct teachings" of the sages. This is discussed in Section 4.2. Yanagida initially did not realize that 涸 was a phonetic loan and translated the passage literally (see Yanagida 1964, p. 17). However, he later retranslated this phrase as "confusions of the shuǐè [type] arise easily" in his article on the development of the yǔlù genre (“水涸の混亂が起りやすく[ . . ]", Yanagida 1985, p. 235). Demiéville was similarly misled: “On peut toujours penser à un assèchement des eaux [perte de la tradition] et à la confusion des caractères wou (corbeau) et ma (cheval) [erreurs dans la tradition]" (Demiéville 1970, p. 268).

58 On this common idiomatic expression, see Section 4.2. Kinugawa offers more of a paraphrase of the passage than a translation “その傳承に訛誤の生じていることが懸念される。” (“The fact that errors arise in the transmission [of the teachings] is a source of concern", see also (Kinugawa 2010b, p. 315 (2)); 2010a, p. 9).

59 Chándé 禪德, “Chán-worthy”, honorific title, here referring to Chán practitioners (ZGDJT 1985, p. 698c; Nakamura 2001, p. 1043c).

60 Xiùchū 袖出, lit. “to take [something] out of one's sleeves" (HYDZD 2010, vol. 6, p. 3286, no. 3). Demiéville translates this literally, pointing out that, at the time, large sleeves were sometimes used as pockets (Demiéville 1970, p. 269). Yanagida proposed "to take out”, noting that the term indeed refers to the action of taking something out of one's sleeves (“とり出す。袖の中からひそ かに出す意。", Yanagida 1964, p. 16). However, Yanagida believed that the phraseology was odd and suggested that xiù 袖 might be a mistake for chōu 抽 "to draw out, pull out" (see Yanagida 1964, p. 17). In fact, both options are attested. In CBETA, for example, one can find expressions such as xiùchū shū 袖出書 (F: 4; identical textual unit), xiùchū qí wén 袖出其文 (F: 4; ibid.), xiùchū $y \bar{\imath} \operatorname{sh} \bar{u}$ 袖出一書 (F: 3; ibid.), xiùchū wénshū 袖出文書 (F: 1), xiùchū xīn juàn 袖出新卷 (F: 1), and so forth, but also expressions with chōu(chū) 抽出, such as chōu shū 抽書 (F: 2; including one in the ZTJ), chōu wénshū 抽文書 (F: 1), chōuchū wénshū 抽出文書 (F: 1).

$61 M \grave{u}$ 目, used as a verb, “to give the title; to title”. See, for example, Yáng Yì's (second) preface to the Jinngdé chuándēng lù: 「由七佛 以至大法眼之嗣，凡五十二世，一千七百一人。成三十卷，目之曰《景德傳燈錄》。」 (see lines 18 and 19 in Zhāng 1935, vol. 1; Féng 2019, p. 2).

62 Considering the parallel syntactic structure of the clauses, in kě wèi zhūyù liánhuán 可謂珠玉聯環, kě works as an auxiliary verb, wèi functions as the main verb of the verbal predicate ("it may be called; it may be said"), and zhūyù liánhuán is the object of wèi, which in turn consists of a subject, zhūyù ("pearls and jade gemstones"), and the disyllabic verb liánhuán ("to string together, 
to thread"), being the verbal predicate. Alternatively, liánhuán could be understood as a noun, "chain, bracelet" (equivalent to liánhuán 連環; HYDCD 1986-1996, vol. 8, p. 708), but this is less likely considering the syntactic parallelism. Yanagida's (1964, p. 18) rendering is close to ours, while Demiéville uses "un collier de perles et de jade" (Demiéville 1970, p. 269). The expression is used to praise the quality and value of the compilation (see Section 4.3).

63 Hàohàn 浩瀚, lit. "vast" (for ocean or large body of water), also used figuratively to describe the expanse of books (HYDCD 1986-1996, vol. 5, p. 1217) or the vastness of the Buddhist teachings. See, e.g., the Guăng qingliáng zhuàn 廣清涼傳 (CBETA 2019.Q4, T51, no. 2099, p. 1114b24). Demiéville has "un volume considérable à enrouler et à dérouler" (Demiéville 1970, p. 269). However, hàohàn is more likely used in a figurative sense, i.e., "vast; rich" (guăngbó 廣博; HYDCD 1986-1996, vol. 5, p. 1217, no. 2), with juănsh $\bar{u}$ 卷舒 (lit. “to roll out and roll up") referring to the ZTJ itself. Yanagida's (1964, p. 18) understanding is close to ours. See also (Kinugawa 1998, p. 116) and Section 4.3.

64 Fèng 奉 can be interpreted in several ways. Among its basic meanings are "to hold respectfully with both hands" or "to receive from; to present to (a superior)", "to esteem, to respect" (GDHYCD 2003, pp. 413-14; HYDZD 2010, vol. 1, p. 574), implying deference or respect (Kroll 2015, p. 116). By extension, fèng also came to be used as a term of respect (jìngcí 敬辭; see HYDZD 2010, vol. 1, p. 575, no. 17). In the present context, in light of the parallel syntactic structure of “既得奉味，但覺神清。”, fèng probably does not act as the main verb of the clause (with dé 得 as modal verb), but rather as a verbal adjective (and dé being the main verb). As for the common noun wèi 味 (lit. "savor; flavor"), which we render with "delicacy", the term figuratively refers to the ZTJ's purport (yìyì 意義, zhĭqù 旨趣; see HYDZD 2010, vol. 2, p. 645, no. 5), with a distinct positive undertone, as in făzèi 法味 ("savor/ flavor of the dharma"; FGDCD 1989, p. 3357) or chánwèi 禪味 ("savor/flavor of meditation"; FGDCD 1989, p. 6455).Shén 神 is used in the sense of jīngshén 精神 “spirit, vital force, vitality" or yishi 意識 “consciousness; awareness" (GDHYCD 2003, p. 1387; Wáng 2000a, p. 1905; Wáng 2000b, p. 830).Qīng 清 is either synonymous with qingping 清平 "peaceful; tranquil” or, more likely, with qingshuăng 清爽 “refreshed” (GDHYCD 2003, p. 1258), as in shénqinng qishuăng 神清氣爽, an idiomatic expression describing a refreshed and relaxed state of mind, free from worries (see Wáng and Guō 1997, p. 450).

65 Zhishu 直書 is common in the meaning “to write faithfully; to record according to the facts" (HYDCD 1986-1996, vol. 1, p. 861). This is in accord with the basic meaning of zhi 直 as adjective, "straight(forward), upright, direct" (Kroll 2015, p. 606). In the present context, zhi is perhaps better translated as "straightfowardly" in the sense of being "direct and free from deviations or evasiveness" (Gove 1984, p. 781; see also HYDZD 2010, vol. 1, p. 71, no. 18(1)). Demiéville uses "écrit tout droit" (Demiéville 1970, p. 269). Kinugawa's rendering is relatively free (“執筆聊経無詞”; Kinugawa 2010a, p. 9; see also Kinugawa 2010b, p. 314(3)).

66 Shù 庶 is probably used as an adverb, “hopefully, in the hope that", equivalent to dànyuàn 但願 (see, e.g., Bái and Chí 2004, p. 294). In this function, shù can be used in front of the verbal predicate or, as in the present case, at the beginning of the sentence or clause (Zhōngguó shèhuì kēxuéyuàn yǔyán yánjiūsuǒ and Gǔdài hànyǔ yánjiūshì 1999, p. 533). Alternatively, shù could be interpreted as an adjective, "numerous; multitudinous" (synonymous with zhòng 眾 or duō 多; see, e.g., GDHYCD 2003, p. 1462; Wáng 2000b, p. 275). However, this is less likely.

67 Gāorén 高仁, lit. "the highly benevolent [ones]" or "[those who] exalt benevolence" if one interprets gāo 高 in a causative sense. Considering the low frequency of gāorén, rén 仁 ("benevolent, humane") could also, although less likely, be a phonetic loan for rén 人 ("person"), both characters sharing the same Middle Chinese pronunciations (Baxter and Sagart 2014: nyin; Pulleyblank 1991, p. 265: L. rin, E. クin; see Wáng 2006, p. 37). The term gāorén 高人 ("noble person") often refers to religious practitioners (see HYDCD 1986-1996, vol. 12, p. 928, no. 3) and is much more frequent in Chinese Buddhist texts (F: 957; including one occurrence in the ZTJ's entry for Huikě 慧可, juàn 2).Jìqiào 譏誚, “to deride; to ridicule by making sarcastic comments" (“冷言冷語地譏諷”; HYDCD 1986-1996, vol. 11, p. 435), disyllabic verb with $j \bar{\imath}$ 譏, “to ridicule, to satirize" (GDHYCD 2003, p. 688) and qiào 誚, “to blame; to reproach" (GDHYCD 2003, p. 1238).In Kinugawa's understanding, Jingxiū invites the readers not to criticize the compilation because of his clumsy preface (“禪の道に心を寄せられる諸賢には、拙い序のゆえをもって本書をお各めにならぬ ようお願い申しあげ、[ . . ]”, Kinugawa 2010b, p. 314 (3)). Demiéville paraphrases: “Puissent les coreligionnaires de haute vertu ne pas n'en (sic.) vouloir!" (Demiéville 1970, p. 269).

68 Kinugawa interprets năi 乃 as a demonstrative pronoun equivalent to č̌ 此 ("this") and lù 錄 ("record") as a noun referring to the preface (Kinugawa 1998, p. 117). While this is indeed a possibility (see, e.g., HYDZD 2010, vol. 1, p. 56, no. 4(2); Péi 1996, p. 488), năi could also be interpreted as an adverb, equivalent to rúč̌ 如此 or zhèyàng 這樣 ("like this, in this way") (see Bái and Chí 2004, p. 215; Péi 1996, p. 494; Wáng 1986, p. 17), with lù used as a verb, “to record" (HYDCD 1986-1996, vol. 11, p. 1342, no. 1). Note that there is no consensus on the word class of năi in this usage in the specialized dictionaries cited above and that it is still currently debated (see, e.g., Lú 2021). Eventually, năi could also be interpreted as a conjunction or adverb, synonymous with yúshì 於是 ("thereupon") or simply ér 而 ("and (so)") (see, e.g., Wáng 2007, p. 267), with lù used as a verb. Because yúnér (see below) can be preceded by a noun or a verb, it is difficult to determine which of the options listed above is the most likely.Yúnér 云爾 can either be interpreted as "in this way and that is it" (“如此而已”; equivalent to yúněr y̌ry 云爾已矣) or as “it was said like this" (“如此說”) (HYDCD 1986-1996, vol. 2, p. 831, no. 1 and 2; see also Wáng 1986, p. 84; Wáng 2007, p. 107).

69 Chán master Jìngxiū's ID in the Buddhist Studies Person Authority Database (see Fóxué míngxiāng guîfàn zīliàokù jiànzhì jìhuà 2021a; hereafter BSPAD ID) is "A003634"; in the China Biographical Database Project (CBDB), it is "94071". On Wéndèng, see, e.g., (Yanagida 1964, p. 15; Yanagida 1980-1984, vol. 3, pp. 1584-86; Ishii 1985; 1986). A relatively good summary of the research of Japanese scholars on Wéndèng can be found in (Yáng 2006b, pp. 477-80). A more recent account, with additional information, can be found in (Kinugawa 2010a). 
70 In her edition of the ZTJ, Zhāng Měilán indicates that Wéndèng 文僜 might be a mistake for Xǐngdèng 省僜: “[ ... ] 疑”文僜”或即 是“省僜'之誤。” (Zhāng 2009, p. 5, n. 5). However, the Middle Chinese reconstructions of the characters are unrelated and no attested variants that we are aware of would explain the confusion between the two graphs. In addition, the name Wéndèng further appears in the Xuánshā Shībèi Chánshī guănglù 玄沙師備禪師廣錄 (see CBETA 2020.Q4, X73, no. 1445, p. 4c1-2), although likely compiled at a later stage. It is possible that Zhāng Měilán was referring to a suggestion initially made by Ishii Shūdō 石井 修道 (see Ishii 1985, p. 272). However, in the following year, Ishii corrected this himself in another paper related to Wéndèng, based on his discovery that the name also appeared in the text mentioned above (see Ishii 1986, p. 170). On a related note, Albert Welter writes that "[e]lsewhere, he is frequently referred to as Wendeng" (Welter 2006, p. 245, n. 26). However, the only occurrences of "文僜” are in his preface to the ZTJ and in the Xuánshā Shībèi Chánshī guănglù.

71 In Western scholarship, the most widespread romanization is Shěngdēng. However, from a semantic point of view, it is more

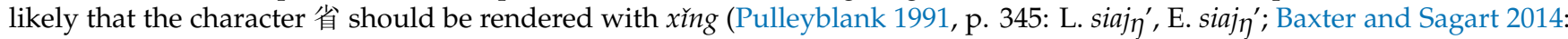
sjengX; see also Kroll 2015, p. 510; HYDZD 2010, vol. 5, p. 2647 (一); GDHYCD 2003, p. 1750). Interestingly, in his 1970 paper on the ZTJ, Paul Demiéville already used "Sing-teng", i.e., Xingdeng, noting only that the pronunciation of the character 僜 was uncertain to him (Demiéville 1970, p. 266, n. 4). The character dèng 僜 is probably not a variant of dēng 燈 (cf. Bā 1965, p. 136) or dēng 登 (cf. Lǐ 1995, pp. 29, 33) but a "standard" or "proper" character (zhèngzì 正字). The graph occurs, for example, in Wéndèng's name in the preface to his QFS (“Chán master Qiānfó Dèng 千佛僜禪師”, see S.1635r_06.11), in the Jīnzàng 金 藏 edition of the JDCDL (Xĩngdèng 省僜, see JDCDL_022-01.17, JDCDL_022-10.12, JDCDL_029-17.21 in Zhōnghuá dàzàngjīng biānjí júbiān 1994, vol. 74, pp. 272, 275, 374), or in the Sibù cóngkān 四部叢刊 edition of the JDCDL (省僜, see JDCDL_022-01.17, JDCDL_022-07.13 and JDCDL_029-12.24 in Zhāng 1935). According to the Guăngyùn 廣韻 (Expanded Rhymes, 1008), one possible Middle Chinese transcription of 僜 (as zhèngzi) would be /dongH/ (“徒亘(=瓦)切, 去嶝定。”; following the system of Baxter and Sagart 2014). However, in this usage, 僜 is glossed as part of the rhyming compound (diéyùn 疊韻) lèngdèng 倰僜, “to not get involved in affairs" (“不做事”; see HYDZD 2010, vol. 1, pp. 262, 206; Jiàoyùbù yìtǐzì zìdiǎn 2017). Because the Yùpiān 玉篇 (Jade Chapters, ca. 543) supposedly already recorded this (「僜, 都鄧、徒亘二切。俊僜, 不著事也。」, “[ ... ] to not get attached to affairs"; Jiàoyùbù yìtǐzì zìdiăn 2017), it is not impossible that, by the mid-10th century, this meaning also became associated with the graph 僜. For instance, in the Lidài făbăo jì, we find the phrase “常閑僜僜, 得否? ” ("Always at ease and indifferent; are you able to do this or not?", translation by Adamek 2007, pp. 378-79; note that S.516 uses the reduplication mark; see also CBETA 2021.Q3, T51, no. 2075, p. 192a18). The Middle Chinese transcription of 僜 as /dongH/ seems to be further supported by an alternative form of dèng encountered in the ZTJ, where the dharma-name (huì 諱) of Wéndèng is written Xĩngdèng 省澄: 「福先招 慶和尚嗣保福, 在泉州。師諱省澄, [ . . . ] 」 」(ZTJ_013-11.14; ZBK, p. 502). Indeed, according to the Jíyùn 集韻 (Collected Rhymes, 1039) and the Lèipiān 類篇 (Classified Chapters, 1066), /dongH/ (“唐亘切”) is one possible Middle Chinese transcription of 澄 (see Jiàoyùbù yìtǐzì zìdiăn 2017). The alternative would be that the graph was misinterpreted by the Goryeo editors when the text was prepared for the carving enterprise.

72 In line with the preface, in the title of the work, Qiānfó likely refers to Qiānfó Dèng 千佛僜, i.e., Wéndèng (see note above and Yanagida 1976, p. 465). In English, sòng 頌 is usually translated as “laud, hymn, eulogy" (Kroll 2015, p. 431, no. 1a), while zàn 贊 is rendered with "encomium, laud" (Kroll 2015, p. 583, no. 2a) or "praise verse, summary verse" (Mazanec 2017, p. 109).

73 See, e.g., (Yanagida 1953, pp. 55, 61-65; Xiàng 2005). For a discussion and TEI-based edition of the Dūnhuáng manuscript, see ( Van Cutsem 2021).

74 These are the Shì zhí zuòchán zhě 示執坐禪者 (lit. “Teaching the one who clings to seated meditation") and the Shì zuòchán fāngbiàn 示坐禪方便 (lit. “Teaching the skillful means of seated meditation"). See JDCDL_029-12.24 to JDCDL_029-13.26 in (Zhāng 1935, vol. 10); see also (Féng 2019, p. 877).

75 The Ziyún monastery 紫雲寺 is an alternative name of the Quánzhōu Kāiyuán monastery 泉州開元寺 (Lǐ 2006, p. 211). The Ž̌yún kāishì zhuàn was compiled by Shì Dàguī 釋大圭 (1304-?; BSPAD ID: A003579) in the Yuán 元 dynasty (Kinugawa 2010a, p. 26).

76 The section of the text that is of particular importance regarding the events related to Wéndèng is also known as the Wēnling Kāiyuánsì zhì 溫陵開元寺志 (Gazetteer of the Wēnling Kāiyuán monastery), Wēnlíng 溫陵 being an alternative name of Quánzhōu (see Zhèng et al. 1996, p. 915). Ishii refers to it as the Quánzhōu Käiyuánsì zhì (see, e.g., Ishii 1985, p. 270), while Kinugawa uses Wēnling Käiyuánsì zhì (see, e.g., Kinugawa 2010a, p. 3). The text was prefaced by Yǒngjué Yuánxián 永覺元賢 (1578-1657), a monk of the Yǒngquán Chán monastery 涌泉禪寺 of Mt. Gǔ 鼓山 in Fúzhōu, in the 16th year of the reign of Emperor Chóngzhēn 崇禎 (1643) (Ishii 1986, p. 169; Yáng 2006b, p. 477). An online, marked-up edition was produced by the Dharma Drum Institute of Liberal Arts (http:/ / buddhistinformatics.dila.edu.tw/fosizhi/ui.html?book=g062\&cpage=0015, accessed on 1 August 2021).

See, e.g., ZTJ_013-11.14 to 15; (Sūn et al. 2007, p. 599). Following Hugh R. Clark, we distinguish between "Quánzhōu prefecture", which included several districts or counties such as Xiānyóu or Nán'ān 南安, and "Quánzhōu (prefectural) city" corresponding to the political center of the prefecture in Jinjiāng county 晉江縣 (see Clark 1991, pp. 7-9).

78 ZTJ_013-11.15 to 16; (Sūn et al. 2007, p. 599); See also (Ishii 1986, p. 171; Wáng 1997, p. 202, n. 2). The Lónghuá monastery was located in Xiānyóu county (Lî 2006, p. 212). Note that twenty years is supposedly the minimun age required to take the full precepts (Nakamura 2001, p. 323a; FGDCD 1989, p. 3078; see also e.g., ZTJ_005-03.05; ZBK, p. 186).

79 ZTJ_013-11.16; (Sūn et al. 2007, p. 599); Ž̌yún kāishì zhuàn, juàn 2 (cited in Kinugawa 2010a, p. 5).

80 ZTJ_013-11.18 to 19; (Sūn et al. 2007, p. 599). Following the research of Japanese scholars, “Ānguó 安國” does not refer to Ānguó Hóngtāo 安國弘瑫 (d.u.) (as stated, e.g., in Yáng 2006b, p. 477) but to the Ānguó temple 安國院, rebuilt by Wáng Shěnzhī 王審知 (862-925), ruler of the Mǐn kingdom 閩, in the second year of the Qiánníng 乾寧 era (895). Based on information provided in the Xuánshā Shībèi Chánshī guănglù, it can be inferred that Ānguó refers to Xuánshā Shībèi, who was invited by Wáng Shěnzhī to 
serve there as abbot in the beginning of the Guānghuà 光化 era (ca. 898), and who received the visit of Wéndèng (Yanagida 1953, p. 45; Ishii 1985, pp. 272-73; 1986, p. 171).

ZTJ_013-11.19 to 24; (Sūn et al. 2007, pp. 599-600); Ž̌yún kāishì zhuàn, juàn 2 (cited in Kinugawa 2010a, p. 5).

(Yanagida 1980-1984, vol. 3, pp. 1584-85). Note that Yanagida wrote, likely by inadvertence, that he was a third-generation dharma-heir of Yìcún (“つまり、文僜は雪峰下3世の孫である。”; Yanagida 1980-1984, vol. 3, p. 1585).

(Zhāng 2009, p. 7). Wáng Róngguó 王榮國 appears to be of the same opinion (Wáng 1997, pp. 126, 204-05).

On this topic, see, e.g., (Suzuki 1975; Clark 1991, pp. 60-62; Wáng 1997, pp. 141-54; Welter 2006, pp. 90-113; Brose 2015, pp. 45-70).

ZTJ_013-11.24; (Sūn et al. 2007, pp. 599-600); Ž̌ún kāishì zhuàn, juàn 2 (cited in Kinugawa 2010a, 5).

Ž̌yún kāishì zhuàn, juàn 2:「宋興一天下, 徐相爲藩表聞, 太祖嘉之, 賜真覺師名。開寶五年閏月示疾，七日，以此月晦，別其 徒而化。壽八十一, 臘六十一。塔郡東北十五里萬安院, 曰瑞光塔, 蓋紀白光異也。」 (cited in Kinugawa 2010a, p. 5). See also the abbreviated corresponding passage in the Quánzhōu Kāiyuánsì zhì (Dù 1982, vol. 8, p. 66; see also Ishii 1986, pp. 170-71, 183; Yáng 2001, p. 5).

Quánzhōu Kāiyuánsì zhì:「唐垂拱三年, 州民黃守恭園桑生白蓮。有司以聞, 乞置道場。制曰:「可」, 賜名蓮花。」(Dù 1982, vol. 8, p. 54). According to Yáng (2001, p. 4), the monastery was also known as the Báilián Ruììng temple 白蓮瑞應道場.

(Yáng 2001, p. 4; Kinugawa 2010a, p. 3). On the Quánzhōu Kāiyuán monastery, see also (Lǐ 2006, pp. 211-12; Wú and Wú 2005, pp. 529-55).

Ž̌yún kāishì zhuàn, juàn 2:「梁天成時，刺史王延涁創千佛院，致僜住持之，十餘年足不越臬。」 (cited by Kinugawa 2010a, p. 5; note that the text should read [後]唐天成時; see also the corresponding passage of the Quánzhōu Kāiyuánsì zhì in Dù 1982, vol. 8, p. 65, or Ishii 1986, p. 169). Wáng Yánbīn had taken on the function of his father Wáng Shěnguī 王審邽 (858-904) as cìsh Quánzhōu prefecture in the first year of the Tiānyòu 天祐 era of the Táng (904). As Suzuki Tetsuo 鈴木哲雄 pointed out, this was probably part of Wáng Yánbīn's strategy to promote Quánzhōu prefecture as the center of (Chán) Buddhism in the Mĩn kingdom, against Fúzhōu in the north (see Suzuki 1975, p. 111).

This appears to be confirmed by the following passage in Wéndèng's entry in juàn 13 of the ZTJ:「問: 『九年少室，五葉花開; 十載白蓮，今日如何垂示?』」 (“[The monk] asked: ‘[Bodhidharma spent] nine years [at Mt.] Shăoshì, and five petals opened up (i.e., the five patriarchs, heirs in Bodhidharma's line). [As for you who have resided at the] Báilián [monastery] for ten years, today what will your teachings be like?"'; ZTJ_013-12.16 to 17, ZBK, p. 505; Sūn et al. 2007, p. 601; see also Yáng 2001, p. 4).

Chángqìng Huiléng was the first abbot of the Zhāoqìng monastery, followed by his dharma-heir Zhāoqìng Dàokuāng 招慶道匡 (d.u.) (Yanagida 1980-1984, vol. 3, p. 1585; see, respectively, ZTJ_010-15.14 and ZTJ_013-01.02; ZBK, pp. 400, 482; Sūn et al. 2007, pp. 489, 581). Albert Welter, perhaps by mistake, writes that the Zhāoqing monastery was "founded in 906 through the support of the Min ruler Wang Yanhan" (Welter 2006, pp. 65, 103). In fact, the monastery was built during the Tiānyòu era (904-907) by Wáng Yánbīn, who invited Huiléng to serve as its first abbot in the third year of the same era, i.e., in 906 (JDCDL_018-10.24 and 25 in Zhāng 1935; see also Yáng 2006b, p. 478; Kinugawa 2010a, p. 24).

On this topic, see, e.g., (Davis 2004, pp. 492, 582-83; Yáng 2001, p. 4).

The relevant passage in the Ž̌yún kāishì zhuàn, juàn 2, reads as follows: 「晉開運初，黃紹頗守郡，遷主北山招慶。閩侯文進界明 覺師號。前此號淨修, 淮南吳王稱蹕錫之也。」 (cited in Kinugawa 2010a, p. 5; note that Běishān 北山 refers to Mt. Qīngyuán 清 源山; see also the corresponding passage of the Quánzhōu Kāiyuánsì zhì in Dù 1982, vol. 8, p. 65; on “前此號淨修” see note 98 below). See also (Yáng 2001, p. 5).

(Clark 2009, p. 169; Kinugawa 2010a, pp. 6, 23). In other words, Wéndèng served as abbot of the "Běishān" Zhāoqìng monastery for only ca. nine months (see Ishii 1986, p. 180).

See Zīzhì tōngjiàn 資治通鑑, juàn 285 in (Biāodiăn Zīzhì tōngjiàn xiǎozǔ 1976, p. 9303, no. 6). See also (Clark 2009, p. 169; Davis 2004, pp. 583-84). For a detailed narration of the events involving Liú Cóngxiào, see (Kurz 2011, pp. 54-58, 62).

See Zīzhì tōngjiàn, juàn 288 (in Biāodiǎn Zīzhì tōngjiàn xiǎozǔ 1976, p. 9417, no. 32). The creation of the Qīngyuán military office, which had control over the southern prefectures of Zhāngzhōu and Quánzhōu, reflects the fact that Lǐ Jǐng could not effectively rule these areas. Hugh R. Clark also occasionally refers to a "Zhāng-Quán" area, which was de facto independent from ca. 945 to 978, but nominally subordinate to the Southern Táng (see, e.g., Clark 2009, p. 133).

This monastery is usually referred to as the Nánchán monastery 南禪寺 (see e.g., Yáng 2006b, p. 478; Lǐ 2006, p. 212; Wú and Wú 2005, p. 555). However, it is not clear if it was exclusively known under this name. For instance, the Zìuún kāishì zhuàn, juàn 2 , records the following: 「[ . . ] 未幾, 州亂, 招慶火於兵。留從效以建義節清源軍, 寺其別墅, 名南禪, 歸招慶業, 復以僜第一 世祖。」, cited and punctuated by Kinugawa 2010a, p. 5). See also the corresponding passages in the Liú Ègōng shějiàn Quánjùn Chéngtiān sìyuàn jì 留鄂公捨建泉郡承天寺院記 of Yú Jí 虞集 (1272-1348) in (Zhèng and Dīng 2003, p. 19), and the Quánzhōu Kāiyuánsì zhì in (Dù 1982, vol. 8, p. 65). According to this reading, Liú Cóngxiào transformed his secondary residence into a monastery (or perhaps built a monastery within its domain), giving it the name Nánchán. Thereafter, he transferred the possessions of the Zhāoqìng monastery to this new location and invited Wéndèng to serve as its first abbot (see also Wáng 1997, p. 203; Yáng 2006b, p. 478). In line with Ishii (1986, p. 181), Kinugawa suggests that the Nánchán monastery also continued to be referred to as the Zhāoqìng monastery, before its name was changed to Chéngtiān monastery 承天寺 in the fourth year of the Jingdé 景德 era, i.e., in 1007 (Kinugawa 2010a, pp. 23-24). If the ZTJ was effectively presented to Wéndèng at this new location, this could explain why Wéndèng introduces himself in his preface as the abbot of the "Zhāoqìng monastery". This being the 
case, what is certain is that Liú Cóngxiào built or converted part of his residence into a monastery and had the properties of the previous Zhāoqing monastery transferred there. In this regard, it should be noted that several other monasteries were built or restored by Liú Cóngxiào, who manifestly supported Chán monks, as the Wáng family had done in the past (see Wáng 1997, pp. 160-64).

98 The relevant passage is as follows: 「後以郡使欽仰，請轉法輪，敬奏紫衣，師號淨修禪師矣。」 (ZTJ_013-11.25 to 26; ZBK, p. 503; Sūn et al. 2007, p. 600). From the header of the preface, it can be assumed that the conflicting piece of information provided in the Zǐyún kāishì zhuàn (“前此號淨修, 淮南吳王稱踶錫之也。”) is erroneous (see Kinugawa 2010a, p. 10). Albert Welter (2006, p. 107) identified the jùnshı̌ 郡使 in the passage above as Wáng Yánhàn 王延翰 (d. 927), while Wáng (1997, p. 203) identified him as Wáng Yánbīn (d. 930). In fact, the jùnshǐ most likely refers to Liú Cóngxiào (Ishii 1985, p. 277; 1986, pp. 170, 182; Yáng 2006b, p. 478; Kinugawa 2010a, pp. 9-10, 12).

These were already identified by Yanagida in his study on the value of the materials of the ZTJ (Yanagida 1953, p. 35).

ZTJ_001-13.27 to 14.02; ZBK, pp. 26-27; (Sūn et al. 2007, p. 18).

ZTJ_002-14.02 to 03; ZBK, p. 76; (Sūn et al. 2007, p. 101).

For Huikě, see: ZTJ_002-15.25 to 26; ZBK, p. 79; (Sūn et al. 2007, p. 108). For Sēngcàn, see: ZTJ_002-16.11 to 13; ZBK, p. 80; (Sūn et al. 2007, p. 111). For Hóngrěn, see: ZTJ_002-20.07 to 08; ZBK, p. 88; (Sūn et al. 2007, p. 121). For Huìnéng, see: ZTJ_002-25.09 to 10; ZBK, p. 98; (Sūn et al. 2007, p. 130). There does not appear to be any specific reason for the fact that this formula is not found at the end of Dàoxìn's 道信 entry. Therefore, we agree with Yanagida (1953, p. 35) that it was most likely omitted by mistake.

See, e.g., (Yanagida 1980-1984, vol. 3, p. 1579; Kinugawa 2007, p. 945), with the difference that Yanagida thought that this ZTJ in one scroll corresponded to the present Goryeo edition of the text. Interestingly, an almost identical formula is used in the $J D C D L$ at the end of the entries of the six patriarchs of China, the year identified as the present being the "first year of the Jingde era, Jiăchén [year]” (“景德元年甲辰”), i.e., 1004. For Bodhidharma, see JDCDL_003-13.18 to 19 (in Zhōnghuá dàzàngjīng biānjí júbiān 1994, vol. 74, p. 29); for Huìkě, see JDCDL_003-16.05 to 06 (in Zhōnghuá dàzàngjīng biānjí júbiān 1994, vol. 74, p. 30); for Sēngcàn, see JDCDL_003-21.16 to 17 (in Zhōnghuá dàzàngjīng biānjí júbiān 1994, vol. 74, p. 32); and so forth.

Zǔtáng 祖堂, “patriarchal hall, ancestors' hall”; also known as zǔshī táng 祖師堂, kāishān táng 開山堂, yǐngtáng 影堂, etc. (FGDCD 1989 , pp. 4240, 5299). The zǔtáng is the hall of the monastery that is dedicated to worshipping the "patriarchs" (ž̌sh $\bar{\imath}$ 祖師), i.e., the masters who were thought to have played an important role in the transmission of the authority of the local lineage ( HYDCD 1986-1996, vol. 7, p. 851; ZGDJT 1985, p. 774c). Generally speaking, the figures worshipped in this hall include the $z \overline{o n g z u ̌ ~}$ 宗祖 (founding patriarchs of the school), the kāizǔ 開祖 (initiators of local lineages), and the lièzú 列祖 (successors of the $k \bar{a} i z \breve{u})$. Customarily, the founder and/or first abbot of a monastery is referred to as kāishān 開山 (ZGDJT 1985, p. 774c; FGDCD 1989 , pp. 4239; 5298). The patriarchal hall usually welcomed in its midst the commemorative steles and/or representations of the patriarchs (Nakamura 2001, pp. 182a, 1092a). For an insightful overview of the patriarchal or portrait halls from the Suí 隋 (581-618) up to the Sòng, specifically in the Chán context and with reference to the ZTJ, see (Foulk and Sharf 2003, pp. 88-106). Féng Guódòng 馮國棟 has also suggested that the portraits of Chán masters (zǔtú 祖圖) were accompanied by textual materials in the form of basic biographical information (see Féng 2014, p. 131). Ji 集, “collection; anthology", designates a category of books that consist of various isolated textual units of literary works brought together to form one or more volumes (HYDZD 2010, vol. 7, p. 4403, no. 5). In Western scholarship, the title of the work has been alternatively translated as "Recueil de la Salle des Patriarches" (Demiéville 1970, p. 262), “Anthology of the Patriarchal Hall” (McRae 1986, p. 58; McRae 2003, p. 112), “Patriarch's Hall Anthology" (Welter 2006, p. 20), “Collection from the Patriarchs' Hall” (Anderl 2004, p. xxiv; 2012, p. 11), “Recueil des Salles patriarcales" (Faure 2006, p. 292), "Anthology of the Patriarchal Hall" (Adamek 2007, p. 10); "Anthology from the Patriarchal Hall” (Adamek 2007, p. 290), “Hall of the Patriarchs' Collection” (Poceski 2007, p. 7); “Hall of Patriarchs Collection” (Poceski 2015, p. 199); “Anthology from the Halls of the Patriarchs" (Schlütter 2008, p. 16); "Record of the Patriarchal Hall” (Robson 2009, p. 479); "Patriarch's Hall Collection" (Brose 2015, p. 9); "Patriarchal Hall Collection" (Broughton 2017), etc.First, singular renderings of zǔ 祖 should probably be avoided, but "patriarchs" and "patriarchal" are both acceptable. With regard to táng 堂, the question of singular versus plural is more delicate. Based on the Goryeo edition, it could be argued that it would be more adequate to use the plural, i.e., "halls", as in Faure (2006) or Schlütter (2008), since the materials were obviously not restricted to the patriarchs $(z \bar{o} n g z \grave{u}, k \bar{a} i z \check{u}$, lièzǔ $)$ revered in a local branch of the Chán tradition-for example, that of Wéndèng. However, the question is less evident if we consider that this title was given to the work when it consisted of only one scroll. Since we know little about the original compilation and the intentions of Jing and Yún, this is a question that should be left open. Eventually, regarding the English renderings of $j i$ 集, “collection" and "anthology" are the best options. The first term is derived from Latin collēetiō (n.) and, therefore, colligō (v.), i.e., co(l)- and legō "to gather, collect; to read" (Vaan 2008, pp. 128, 332). Anthology, on the

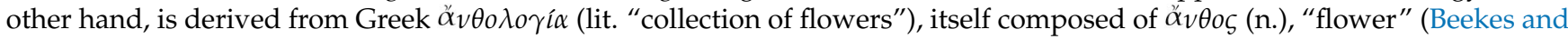

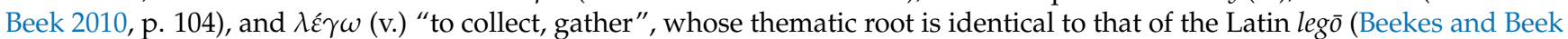
2010, pp. 841-42). As such, the term originally points to a collection of literary pieces specifically chosen for their remarkable quality (see, e.g., Hoad 1996, p. 18). In this respect, "collection" is perhaps more neutral. Yanagida interpreted the ZTJ's title in connection with the epitaphs of the Chán masters and as a collection of the inscriptions recorded on these (see Yanagida 1980-1984, vol. 3, p. 1588).

(ZGDJT 1985, p. 698c). Dàdé is itself a rendering of Skt. bhadanta, a term of respect used for buddhas, bodhisattvas, eminent monks, elders of the monastic community, etc. (FGDCD 1989, p. 879). 
See, e.g., (Yanagida 1980-1984, vol. 3, p. 1584). This is adopted by Welter (2006, p. 25) and Benjamin Brose (2015, p. 8). Suzuki Tetsuo, on the other hand, thought that they were probably disciples of either Huiléng or Cóngzhăn (Suzuki 1975, p. 113). See also note 109.

(Yáng 2006b, p. 479). Kinugawa (2007, p. 954, n. 8), who cites Yáng Zēngwén on this issue, probably agrees with him.

See (Yanagida 1980-1984, vol. 3, p. 1602). Yanagida suggested this very early-for example, in his 1964 paper on the ZTJ's textual study (Yanagida 1964, p. 47). Interestingly, John Jorgensen indicates that although there are obvious connections with Korea, several elements in the received text (e.g., the predominance of Chinese masters, lack of materials related to some Korean masters, indications in Wéndèng's preface) go against the hypothesis of a Korean authorship (Jorgensen 2005, pp. 730-31). The suggestion of Yanagida and other attempts at identifying Jing and Yún in Japanese scholarship are discussed thoroughly by Jorgensen in the second annex to his monograph. Moreover, Jorgensen provides well-researched arguments to support his own evaluation of the identity of the ZTJ's compilers, suggesting Chéngjìng 澄靜 (d.u.; BSPAD ID: A020355) and Zhìún 智筠 (906-969; BSPAD ID: A014271) (Jorgensen 2005, pp. 741-49). This being the case, in the absence of more decisive evidence, the issue of the identity of Jìng and Yún should be left open.

ZTJ_002-01.16 to 19: 「師曰:『善哉真比丘！善會諸佛理，善說真法要，善識諸佛義。』乃命付法，以偈告曰：『心地本無生，因 種從緣起。緣種不相妨，花果亦復然。」(ZBK, p. 51; Sūn et al. 2007, p. 62).

On the term făyào, see, e.g., (FGDCD 1989, p. 3376 (1); ZGDJT 1985, p. 1145a; Nakamura 2001, p. 1521d).

ZTJ_003-01.25 to 02.15: 「融於言下, 雖承玄旨, 而無有對。師於是為說法要曰: [ … ]。師於言下頓盪微瑕, 永亡眹兆。」(ZBK, pp. 100-102; Sūn et al. 2007, pp. 136-37).

Another example is found in the entry of Nányuè Huáiràng 南嶽懷讓, juàn 3, who addresses Măzŭ Dàoyī 馬祖道一, then his student, as follows:「[ . . ] ] 我說法要，譬彼天澤。汝緣合故，當見于道。」(ZTJ_003-22.24 to 25; ZBK, p. 142; Sūn et al. 2007, p. 192).

ZTJ_018-22.15: 「自餘法要及化緣之事, 多備《仰山行錄》。」(ZBK, p. 699; Sūn et al. 2007, p. 823).

See, e.g., (Yanagida 1980-1984, vol. 3, p. 1599). The expression "encounter dialogues" was coined by John R. McRae in his translation of a paper written by Yanagida (see Yanagida 1983, pp. 192, 204, n. 25), where "encounter" roughly renders jīyuán 機 緣 (lit. "pivotal conditions"). See also Demiéville's (1970, pp. 264-65) description.

This was already suggested by Jorgensen (2005, p. 740), although the connection was not made with Wéndèng's preface.

On this topic, see (Foulk and Sharf 2003, pp. 93-100).

ZTJ_001-01.13; ZBK, p. 1; (Sūn et al. 2007, 1). See also below.

Chóngwén zǒngmù, juàn 4 (1968, p. 317); see also (Yanagida 1980-1984, vol. 3, pp. 1596, 1599).

(Kinugawa 1998, p. 122). A much later work, the Guóshǐ jingjí zhì 國史經籍志 (Bibliographic Treatise of the State's History, 1590) of Jiāo Hóng 焦竑 (1541-1620), records a “Zǔtáng jí 祖唐集” in one juàn, where the character 唐 is probably a mistake for 堂. However, it is likely that this work relied on the Tōngzhì (see Chén and Zhōu 2001, pp. 91-92; note that the digital edition in CTEXT is corrupted; see Sturgeon 2021). In the first two pages of their paper, Chén Yàodōng 陳耀東 and Zhōu Jingmǐn 周靜敏 provide an overview of the works that mention the ZTJ and discuss the possible reasons behind the text's short-lived circulation, up to the early Southern Sòng 南宋. This is also summarized in (Zhāng 2009, pp. 4-5).

See, e.g., (Kinugawa 2007, pp. 945-46); on the Chán patriarchs listed in the BLZ, see (Shiina 1980, pp. 236, 243-47). The entries of Dàoxìn, Hóngrěn, and Huìnéng were included in the lost ninth and tenth juàn of the BLZ (Shiina 1980, pp. 245-47). For an overview of the Chán patriarchs listed in various Chán histories, see (Yampolsky 2012, pp. 8-9).

This list is primarily based on the Keitoku dentō shōroku's quotations from the BLZ in its in fifth juàn, with three references to the tenth juàn of the BLZ (see Shiina 1980, pp. 248-49). This manuscript likely dates back to the Muromachi 室町period (1336-1573) and is stored at Komazawa University 駒澤大学 (Shiina 1980, p. 240).

Upon inspection of the manuscript, the section on Xíngsī indeed does not include quotes from the BLZ. The relevant passage in Shítóu's section, also cited by Shiina (1980, p. 249, no. 77), is as follows: 「寶林傳第十： [ . . . ]吉州行司禪師下有一人，名希遷， 俗姓陳氏, 端州高安縣人也。[ ... ] 」 (“Băolín zhuàn, juàn 10: [ . . ] To Chán master Jízhōu Xíngsī succeeded one man. His name was Xīqiān and his secular family name was Chén. He was a man from Gāo'ān county in Duānzhōu."). Note that Xíngsī's name is written 行司, with 司 being a phonetic loan for 思 (Pulleyblank 1991, p. 291: L. sz; E. si). Interestingly, this is also how Xíngsī is written in the QFS (S.1635r_79.16; see Van Cutsem 2021 and below). Compare textual unit no. 62 in Shiina (1980, p. 248) and textual units no. 1 and 2 in Sūn et al. (2007, pp. 189-90). Compare, e.g., textual unit no. 64 in Shiina $(1980$, p. 248) and the end of textual unit no. 2 of Huáiràng's entry and the second part of textual unit no. 2 of Lăo 'ān's 老安 entry in Sūn et al. (2007, pp. 190-91, 153). Compare also the short excerpt no. 67 in Shiina (1980, p. 248) with its counterpart in textual unit no. 4 of Huáiràng's entry in Sūn et al. (2007, p. 191). See beginning of Section 3.2; (Yanagida 1953, pp. 55, 61-65; Yanagida 1980-1984, vol. 3, p. 1585; Lǐ 1995; Van Cutsem 2021). Laurent Van Cutsem is currently preparing a paper on the QFS and its relation to the BLZ and the ZTJ. In his introduction to the QFS, Lǐ Yùkūn 李玉昆 writes, probably by mistake, that a praise verse was also composed for Shénxiù 神秀 (605-706; BSPAD ID: A009582) (Lǐ 1995, p. 29). However, this is not the case. 
Lǐ Yùkūn omits Dàowú (Lǐ 1995, p. 30). Note that among the additional praise verses composed by Wéndèng, the one composed for Huiléng is not a tetrasyllabic octave, but a pentasyllabic quatrain.

See also the .xlsx table in (Van Cutsem 2020c).

For further details, see, e.g., (Yanagida 1980-1984, vol. 1, p. 1, and vol. 3, pp. 1585-86).

See, respectively, (Kinugawa 1998, p. 117) and (Kinugawa 2007, p. 946). On this topic, see also (Xiàng 2005, pp. 182-85).

The Goryeo preface, the expansion to ten juàn, the structure and contents of the received ZTJ, and the text's connection with the Korean context will be discussed in a forthcoming paper.

ZTJ_001-01.13 to 15; ZBK, pp. 1-2; (Sūn et al. 2007, p. 1).

Benjamin Brose has: "[Wendeng's] preface and the Patriarch's Hall Collection in a single fascicle previously circulated in this land. Subsequently, it reached ten fascicles. [ .. . ]" (Brose 2015, p. 172, n. 9). However, this reading is grammatically unlikely. First, qi 齊 is likely used as an adverb, "altogether; jointly" or "simultaneously" (GDHYCD 2003, p. 1187; see also HYDZD 2010, vol. 9, p. 5098; Wáng 2000b, p. 1780; Kroll 2015, p. 356). Second, dào 到 should be understood in parallel with xíng č̌ tǔ 行此土, which more probably refers to the circulation of the preface and the ZTJ from the Chinese territory to the Goryeo kingdom.

For more details, please consult (Kinugawa 1998, p. 122; Kinugawa 2010b, pp. 313(4)-12(5)).

As Kinugawa recounts, this hypothesis was initially raised by Ogata Kōshū 緒方香州, who noted with humor that if there was such a thing as a "long-scroll" ZTJ corresponding to the twenty juàn of the Goryeo edition, it would have looked like a barrel ( Kinugawa 1998, pp. 113-14).

This approximation was retrieved from the Taishō edition of the Lìài făbăo jì (T51, no. 2075), which is primarily based on P.2125 (see Adamek 2007, p. 300) and, probably, S.516. In contrast, the most complete witness manuscript of the Léngqié shīzi jì, i.e., P.3436, consists of ca. 11,000 characters, and that of the Chuán făbăo jì, i.e., P.3664/3559, consists of ca. 4,000 characters (see Bingenheimer and Chang 2018, pp. vii-viii).

See, e.g., (Kinugawa 2007, p. 945; 2010a, p. 10).

See (Jorgensen 2005, p. 740).

Yanagida's (1985, pp. 234-36) observations are adopted by Welter (2008, pp. 85, 185, n. 14). From a methodological point of view, it should be noted that Yanagida was initially searching for this meaning of yánjiào in the ZTJ, based on the fact that Enchin's 圓 珍 (814-891) catalog records a text called the “Nányáng Zhōng guóshī yánjiào 南陽忠國師言教” (see Yanagida 1985, p. 235).

Also referred to as shuĭlăohè 水潦鶴 (HYDCD 1986-1996, vol. 5, p. 890, and vol. 12, 1143; FGDCD 1989, p. 1487). In Chinese, (shui)hè supposedly corresponds to the now critically endangered Siberian (white) crane (Grus leucogeranus; báihè 白鶴) of the Gruidae family (hèke $\bar{e}$ 鶴科), which winters in the region of the Póyáng lake 鄱陽湖 (HYDZD 2010, vol. 8, p. 4926, no. 1; MacKinnon and Phillipps 2000, p. 123). The original Sanskrit term that shuǐhè or shuľlăohè are supposed to translate is baka (or vaka), which is not harmoniously defined in Sanskrit dictionaries. The term is said to either refer to a kind of crane or to a species of white herons (i.e., egrets) in the Ardeidae family (lùkē 鷺科). The species usually referenced is Ardea nivea (see, e.g., Ogiwara et al. 1986, p. 906). However, this specific name is not in use in the modern ornithological literature. The term perhaps refers to the eastern large egret (Ardea alba modesta; see Ali and Ripley 1978, pp. 69-71), sometimes regarded as a subspecies of the great egret (Ardea alba (alba); dà báilù 大白鷺), or to a smaller species like the little egret (Egretta garzetta; báilù 白鷺) (see Hirakawa 1997, p. 1295, no. 4309; HYDZD 2010, vol. 8, p. 4973; Ali and Ripley 1978, pp. 72-74; MacKinnon and Phillipps 2000, pp. 210-11, 212-13).

S.1635r_64.16; see (Van Cutsem 2021).

See ZTJ_002-07.04 to 05; ZBK, p. 62; (Sūn et al. 2007, p. 84).

Yanagida briefly discussed the meaning of shuìhè in Wéndèng's preface, already pointing to a few of the sources mentioned in this section, in his monumental 450-page article on the development of yǔlù (see Yanagida 1985, pp. 235-36). Unfortunately, the authors found out about this only after the research was completed. This being the case, the present analysis is not only more thorough, but it also sheds light on the grey areas and questions left by Yanagida's short survey.

(Sūn et al. 2007, pp. 26-27) (characters regularized; punctuation revised). Note that bùjiàn 不見 ("not see") is substituted by bùhuì 不會 (“not understand") and dǔjiàn 睹見 (“to observe, see") by juéliăo 決了 (“to apprehend, understand clearly"), clarifying that it is not a matter of "seeing with the eyes", but understanding. In addition to the entry of Ānanda, this stanza was also recited verbatim by the 18th patriarch Jiāyéshěduō 伽耶舍多 (Skt. *Gayāsata) when he was a boy during an exchange with the 17th patriarch Samghanandi (see ZTJ_002-01.08 to 09; ZBK, p. 50; Sūn et al. 2007, p. 61).

Tú 徒 is probably used as an adverb, “in vain; to no avail” (HYDZD 2010, vol. 2, p. 885, no. 15; Kroll 2015, p. 460). On the other hand, in view of its direct object, zài 載 could be interpreted in several ways. In our view, the most likely, in order, are (1) “to know" or "learn, commit to memory" (HYDZD 2010, vol. 6, p. 3761, no. 14), especially considering the context of the narrative and Ānanda's presence; (2) “to record" (HYDZD 2010, vol. 6, p. 3762, no. 2); or (3) “to collect and store up" (HYDZD 2010, vol. 6, pp. 3760-61, no. 8). Kōngshēn 空身 is likely used in its secular meaning, i.e., "without any burden" (physically or mentally) (see HYDCD 1986-1996, vol. 8, p. 413, no. 1). To the best of our knowledge, the present passage, omitted by Yanagida (1985), appears for the first time in the $B L Z$ in order to paraphrase in verse form a short sermon given by Ānanda, preserved in earlier accounts (see note 149).

This section is extant in the Jīnzàng version of the BLZ (BLZ_002-02.12 to 22 in Zhōnghuá dàzàngjīng biānjí júbiān 1994, vol. 73, p. 610). In this edition, however, juàn 2 was reconstituted based on another text, i.e., the Shèngzhòu jí 聖贯集, compiled ca. 899 (see BLZ_002-01 in Zhōnghuá dàzàngīing biānjí júbiān 1994, vol. 73, p. 610; Shiina 1980, pp. 235, 243; 2000, pp. 68-69). The 
Shèngzhòu jí survives in several manuscripts (e.g., S.4478, P.3913) and in the Jĩnzàng edition of the BLZ (Tanaka 2002). Among the extant manuscripts, this passage occurs in S.4478. Our transcription is as follows: 「阿難至一竹林, 聞一比丘誤念偈云: 『若 人生百歲, 不見水潦涸。不如生一日, 而得睹見之。』阿難聞已, 嗟歎曰:「世間一凡有, 不解諸佛意。徒載四圍陀, 不如空身 睡。」言已，乃語彼比丘曰:「此非佛偈。如今當聽吾為你宣佛偈云：『若人生百歲，不會諸佛機。未若生一日，而得決了之。』」 (S.4478_61 to 66; variant characters regularized). The phraseology is very close to the passage of the ZTJ that is said to rely on the BLZ. As such, the compilers of the ZTJ may have directly quoted from the latter, without much editorial work. Note that in addition to the occurrences of 水潦涸 recorded in CBETA, the phonetic loan appears in this manuscript as well (S.4478_62.08).

The Āyùwáng zhuàn is a translation of the *Aśokarājāvadāna conducted by the Parthian Ān Făqīn 安法欽 in ca. 300. The extant Sanskrit version of the text is part of the Dioyāvadāna (Mūlasarvāstivādin vinaya) (Strong 1989, p. 16). Unfortunately, the present narrative is not recorded in this version (Brough 1962, p. 45; Strong 1989). This passage is also found in the Āyùwáng jīng 阿育王 經 (Sūtra of King Aśoka; T50, no. 2043), translation of the *Aśokarājāsūtra by *Samghabhara 僧伽婆羅 in 512 (Strong 1989, p. 16). However, the $g \bar{a} t h \bar{a} s$ and other passages differ importantly (see CBETA 2019.Q4, T50, no. 2043, p. 154b28-c15). The narrative is further cited in the influential Fù făzàng yīnyuán zhuàn 付法藏因緣傳 (Account of the Avādana of the Transmission of the Dharma Treasury; T50, no. 2058), which in this case draws on the Āyùwáng zhuàn and not the Âyùwáng jīng (see CBETA 2019.Q4, T50, no. 2058, pp. 302c02-303a6). Naturally, the Fù făzàng yinnyuán zhuàn is known as one of the primary sources in the development of the Chán list of Indian patriarchs (see, e.g., Tanaka 1962; Adamek 2007, pp. 101-10; Young 2015, especially Chapter 2).

Āyùwáng zhuàn, juàn 4:「尊者阿難在竹林園中, 聞一比丘誦法句偈言: 『若人生百歲, 不見水老鶴, 不如生一日, 得見水老鶴。』 尊者阿難在傍邊過已語言:「子！佛不作是說。佛所說者: 『若人生百歲, 不解生滅法。不如生一日, 得解生滅法。』」」(CBETA 2020.Q4, T50, no. 2042, p. 115b19-25; punctuation modified). This narrative was translated into French by Jean Przyluski in 1923 as follows: “Le vénérable Ānanda se tenait dans le Parc des Bambous. Il entendit un bhikṣu qui récitait une gāthā des Sentences de la Loi (Dharmapada): «Si un homme vivait cent ans sans voir le vieux héron des marais, il vaudrait mieux qu'il ne vécût qu'un jour et qu'il pût voir le vieux héron des marais. » Le vénérable Ānanda, étant passé à côté du bhikṣu, lui dit: "Mon fils! le Buddha n'a pas prononcé ces paroles. Voici ce qu'a dit le Buddha: «Si un homme vivait cent ans sans comprendre la loi de la transmigration, il vaudrait mieux qu'il ne vécût qu'un jour et qu'il comprît la loi de la transmigration. "” (Przyluski 1923, pp. 335-36). Note that lăo 老 in shuĭlăohè 水老鶴 is a phonetic loan for lǎo 潦, both characters sharing the same Middle Chinese pronunciation ( Pulleyblank 1991, p. 184: L. law', E. law'). Therefore, the adjective "vieux" in Przyluski's translation can be ignored.

Dhp. 113: “Yo ca vassasatam jīve, apassam udayabbayam; ekāham jīvitam seyyo, passato udayabbayam." (Brough 1962, p. 45; and Sū 2016, p. 136; see also Carter and Palihawadana 2000, p. 21). The earliest extant Chinese translation of the Dharmapada, the Făjù jīng 法句經 (T04, no. 210; translated by Zhú Jiāngyán 竺將炎 and Zhī Qiān 支謙 in 224), juàn 1, renders the stanza as follows: “若人壽百歲, 不知成敗事, 不如生一日, 見微知所忌” (Dhammajoti 1995, p. 301).

(Norman 1997, pp. 107-8). In Sanskrit, the terms in question are, on the one hand, udaya ("rising, going up") and udaka ("water"), and, on the other hand, vyaya ("passing away, mutable, liable to chance or decay") and baka or vaka ("a kind of heron or crane") (Monier-Williams 1899, pp. 186, 183, 1032, 719, accessed online through Universität zu Köln: Institut für Indologie 2021). Interestingly, similar confusions emerging from the term udaya-vyaya appear directly in stanzas of the Chinese translations of the Dharmapada. In stanza no. 374, for example, instead of the expected shēngmiè 生滅 (Skt. udaya-vyayam), we find rúshuř 如水 (Skt. *udaka-viya). This error occurs in the Făjù jīng, the Chüyào jīng 出曜經 (T04, no. 212), but also in the later Făjí yàosòng jīng 法集要頌 經 (T04, no. 213) (see Sū 2016, pp. 135-38).

The Gāndhārī Dharmapada 317 has udaka-vaya (Brough 1962, p. 168). Brough voices his understanding of the narrative as follows: "An interesting episode in the writings of the Mūla-sarvāstivādins shows an awareness of the existence of a Prakrit Dharmapada; and although there is no certainty that the text referred to was the present recension, we can hardly doubt that the criticism was directed against a version in Gāndhārī, or one imperfectly translated into Sanskrit from a Gāndhārī original. [ ... ] The story is thus merely the vehicle of a proposed emendation of a text which was corrupt or was at least thought to be corrupt. If the verse under criticism was at the time still in a Prakrit form, it may not have been thought by those reciting it to refer in fact to a 'water-heron'; and the Mūla-sarvāstivādins author may have been merely indulging in ridicule without adequate justification. On the other hand, it is not impossible that the verse (which might easily have been written with the spelling udaka-vaka in some Kharoșthī manuscript) had been translated carelessly into Sanskrit as apaśyann udaka-bakam, in which case the emendation proposed was most essential" (Brough 1962, pp. 45-46).

See note 148. The passage is as follows: 「彼比丘聞已, 即歸白師說阿難所正之偈。彼師曰:「阿難老朽, 記念非真, 智慧衰殘, 言多錯謬, 慎勿隨之。」阿難却後依前聞誦惨偈, 謂曰:「我曾教汝佛偈, 何故由念邪言?」比丘曰:「我師教招不令棄捨。」阿難 返自思惟，［… ]」（BLZ_002-02.12 to 03.05, in Zhōnghuá dàzàngjīng biānjí júbiān 1994, vol. 73, pp. 610-11; punctuation and regularization is ours). Interestingly, however, this passage is not recorded in S.4478, i.e., the only other extant version of the Shèngzhò jí that contains the entry of Ānanda, which seems to have been abridged. This would deserve further research.

CBETA 2021.Q2, T50, no. 2042, p. 115b25-c13. Cf. Przyluski's translation (Przyluski 1923, pp. 336-37). See also the Fù făzàng yīnyuán zhuàn (CBETA 2021.Q2, T50, no. 2058, pp. 302c15-303a06).

(ZGDJT 1985, pp. 635d-636a); see also (FGDCD 1989, p. 1487), although probably based on the former. Zhān's (2018, p. 104) assessment is mostly based on the FGDCD and no further research was made on the circumstances of the original narrative.

See, e.g., (Wú 2001, pp. 965, 1705; Xú 2009, pp. 181, 88; Tián 2004, pp. 1234, 2317). Similar expressions include hàishǐ lǔyú 亥豕魯

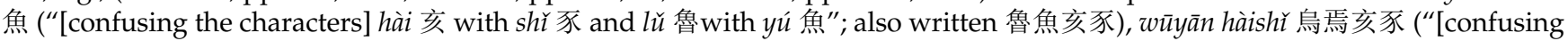
the characters] $w \bar{u}$ 烏 with yān 焉 and hài 亥 with sȟ̌ 豕"), etc. 
Compare CBETA 2020.Q4, T24, no. 1451, pp. 409c26-410b14 and CBETA 2020.Q4, X64, no. 1261, p. 400c6-18. The precision of the monk's name is an element that, to the best of our knowledge, is not present in previous accounts of the narrative. See, e.g., the Fù făzàng yīnyuán zhuàn (CBETA 2019.Q4, T50, no. 2058, pp. 302c02-303a6) or the Făyuàn zhūlín 法苑珠林 (CBETA 2019.Q4, T53, no. 2122, p. 1009a11-b6), which presumably cites the former.

CBETA 2019.Q3, X64, no. 1261, p. 400c19. Surprisingly, Yanagida did not refer to the ZTSY in this case and noted only that the expression was a Chinese "saying" indicating confusion between graphically similar characters (see Yanagida 1985, p. 236). (Foulk and Sharf 2003, p. 95). To give but one example, the Ānguó temple, i.e., the temple where Xuánshā Shībèi served as abbot and where Wéndèng paid him a visit, had to be restored by Wáng Shěnzhī following the events of the Huìchāng persecution ( Ishii 1986, p. 171).

See, e.g., (Ishii 1986, pp. 178-82; Clark 2009, pp. 168-70) (note that it is of course Liú Cóngxiào who held "real power in Ch'üan-chou" and not Lǐ Réndá 李仁達 (d. 947)).

Cf. Yanagida who referred to this passag
Yanagida 1980-1984, vol. 3, p. 1600).

(GDHYCD 2003, p. 1626; Wáng 2000b, p. 110; Kroll 2015, p. 474).

(HYDZD 2010, vol. 2, p. 645, no. 5; GDHYCD 2003, p. 1626).

(HYDCD 1986-1996, vol. 7, p. 640).

In this respect, it should be noted that in recent scholarship, much attention has been paid to the ZTJ's socio-political or sectarian background (e.g., Welter 2006; Brose 2015) and to its linguistic features (e.g., Zhāng 2003; Anderl 2004; Kinugawa 2010b; Zhān 2018). However, with the exception of the pioneering work of Japanese scholars such as Yanagida, little has been done in terms of intellectual history and Buddhology per se. This contrasts with the qualitative research of John R. McRae, Bernard Faure, John Jorgensen, Jiă Jìnhuá, and Wendi L. Adamek on earlier Chán histories (e.g., McRae 1986; Faure 1997; Jorgensen 2005; Jia 2006; Adamek 2007).

See (Kinugawa 1998, p. 116). Note that Kinugawa, probably by inadvertence, omitted Bodhidharma's entry.

Kinugawa gradually became more suggestive in this respect: “[ ... ] 由此推想靜、筠二禪德袖出所示的一卷本大概相當於現行二 十卷的前兩卷。" ("From this, one can infer that the one juàn version presented by the two Chán-worthies Jîng and Yún roughly corresponds to the first two juàn of the current twenty-juàn [edition].”, Kinugawa 2007, p. 945); or “[ ... ]1 卷本の範圍は現行20卷 本の前2卷と推測される。” “[ ... ], it can be inferred that the scope of the one juàn version corresponds to the first two juàn of the present twenty-juàn version.", Kinugawa 2010b, p. 313(4)).

Albert Welter writes that "[t]he preface by Wen (or Sheng) deng [ . . ] confirms that the text was gathered for use by Wendeng and his students." (Welter 2006, p. 63). While not unreasonable, this is not explicitly stated in the preface.

See (Yanagida 1980-1984, vol. 3, p. 1589). This is adopted without further discussion by Welter: "It (i.e., the ZTJ) was compiled expressly at the request of $\mathrm{Li}$ Jing, the Southern Tang ruler who assumed control over Min territory at its demise in 945" (Welter 2006, p. 65).

In a supplementary note at the end of his paper, Ishii Shūdō mentions a lecture given by Yanagida in March 1986 during which the relation between the ZTJ and the Southern Táng context was further examined. In particular, it would seem that Yanagida alluded to: (a) the date recorded in the first two juàn, i.e., the tenth year of the Băodà era of the Southern Táng; (b) the role played by Xú Xuàn in the attribution of the dharma-name Zhēnjué 真覺 to Wéndèng by Zhào Kuāngyìn; and (c) the fact that Xú Xuàn was the author of the stele inscription of Héshān Wúyīn 禾山無殷 (884-960?; BSPAD ID: A014250), whose entry in juàn 12 of the ZTJ is relatively long (Ishii 1986, p. 195; see also Van Cutsem 2020c). Ishii then lists the occurrences of the Xīnhài 辛亥 (F: 5) and Gēngxū 庚戌 (F: 1) years, which all appear in juàn 12 of the ZTJ, most of them attesting to a relation of some sort with Southern Táng officials through the bestowal of dharma-names and invitation to the capital (Ishii 1986, pp. 196-97). This being the case, the above cannot serve as enough evidence to affirm that the ZTJ was commissioned by Lǐ Jinng.

The JDCDL, initially known as the Fózǔ tóngcān jí 佛祖同參集, was compiled by Dàoyuán around the first year of the Jǐngdé era (ca. 1004-1007) of the reign of Zhào Héng 趙恆 (968-1022; r. 997-1022; temple name Sòng Zhēnzōng 宋真宗), third emperor of the Northern Sòng. It was presented at the imperial court around the second or third year of the Jǐngdé era (1005 or 1006). Subsequently, the text was edited by Yáng Yì, Lǐ Wéi 李維 (d.u.), Wáng Shǔ 王曙 (963-1034), and other officials, a process that most likely ended around the second year of the Dàzhōng xiángfú 大中祥符 era (1009) of Zhēnzōng's reign. Eventually, it was integrated into the Buddhist canon in the fourth year of the Dàzhōng xiángfú era (1011) (see Yáng 2006a, pp. 70-72; Féng 2014, pp. 120-25; Kinugawa 2010b, pp. 313(4)-12(5)).

Yanagida's approach is summarized by Bernard Faure as follows: “For Yanagida, although traditional Chan historiography cannot claim the status of a truthful narrative, neither can it be dismissed as an empty fabrication. Yanagida criticized both the mythifying narrative of the 'Histories of the Lamp' and the demythifying history of hyper-historicism, and attempted to emphasize the religious creativity of those 'inventions"' (Faure 2003, p. 3). More recently, James Robson has discussed the inadequacy of hyper-critical scholarship in a very insightful "book review" paper (Robson 2011). 


\section{References \\ Primary Sources}

Chóngwén zǒngmù 崇文總目. 1968. Táiběi 臺北: Táiwān shāngwù yìnshūguăn 臺灣商務印書館.

Jǐngdé chuándēng lù 景德傳燈錄. 1935. In Sỉbù cóngkān sānbiān 四部叢刊三編, Zỉbù 子部. Shànghăi Hánfēnlóu yǐngyìn Chángshú Qú shì Tiěqin Tóngjiànlóu cáng Sòng kèběn 上海涵芬樓景印常熟䨉氏鐵琴銅劍樓藏宋刻本. Compiled by Zhāng Yuánjì 張元濟. 10 vols. Shànghăi 上海: Shāngwù yìnshūguăn 商務印書館.

Jǐngdé chuándēng lù 景德傳燈錄. 1994. In Zhōnghuá dàzàngjīng: Hànwén bùfèn 中華大藏經: 漢文部分. Edited by Zhōnghuá dàzàngjīng biānjí júbiān 中華大藏經編輯局編. Běijīng 北京: Zhōnghuá shūjú 中華書局, vol. 74, pp. 1-395.

Keitoku dentō shōroku 景德傳燈抄錄. Muromachi 室町 period. Tōkyō 東京: Komazawa daigaku toshokan 駒澤大學圖書館.

Quánzhōu Qiānfó xīnzhù zhūzǔsh̄̄ sòng 泉州千佛新著諸祖師頌, Or.8210/S.1635, British Library, London. Digitized by the International Dunhuang Project 國際敦煌項目. http:/ /idp.bl.uk/ (accessed on 1 April 2021).

Shèngzhòu jí 聖贯集. Or.8210/S.4478, British Library, London. Digitized by the International Dunhuang Project 國際敦煌項目. http: / /idp.bl.uk/ (accessed on 1 April 2021). See also juàn 2 of the Shuāngfēngshān Cáohóuxī Băolín zhuàn (see below).

Shuāngfēngshān Cáohóuxī Băolín zhuàn 雙峰山曹侯溪寶林傳. 1994. In Zhōnghuá dàzàngjīng: Hànwén bùfèn 中華大藏經: 漢文部分. Edited by Zhōnghuá dàzàngjīng biānjí júbiān 中華大藏經編輯局編. Běijīng 北京: Zhōnghuá shūjú 中華書局, vol. 73, 601-75.

Sodōshū 祖堂集. 1994. Edited by Zen bunka kenkyūjo 禅文化研究所. Kyōto 京都: Zen bunka kenkyūjo 禅文化研究所.

Zǔtáng jí 祖堂集. 1994. Shànghǎi 上海: Shànghǎi gǔjí chūbănshè 上海古籍出版社.

Zǔtáng jí 祖堂集. In Gāolí zàngjīng bǔyí 高麗藏經補遺. 18 vols. Kyōto 京都: Library of the Institute for Research in Humanities 人文科學 研究所圖書室, Kyōto University 京都大學, vol. 6.

\section{Secondary Literature}

Adamek, Wendi L. 2007. The Mystique of Transmission: On an Early Chan History and Its Context. New York: Columbia University Press. [CrossRef]

Ali, Sálim, and S. Dillon Ripley. 1978. Handbook of the Birds of India and Pakistan: Together with Those of Bangladesh, Nepal, Bhutan and Sri Lanka, 2nd ed. 10 vols. Delhi: Oxford University Press, vol. 1.

Anderl, Christoph. 2004. Studies in the Language of Zu-Tang Ji. 2 vols. Oslo: Unipub.

Anderl, Christoph. 2012. Chan Rhetoric: An Introduction. In Zen Buddhist Rhetoric in China, Korea, and Japan. Edited by Christoph Anderl. Leiden: Brill, pp. 1-94. [CrossRef]

Anderl, Christoph. 2017. Medieval Chinese Syntax. In Encyclopedia of Chinese Language and Linguistics. Edited by Rint Sybesma. Leiden: Brill, vol. 2, pp. 689-703. [CrossRef]

Anderl, Christoph. 2020. Some Reflections on the Database of Medieval Chinese Texts as a Multi-Purpose Tool for Research, Teaching, and International Collaboration. In Corpus-Based Research on Chinese Language and Linguistics. Edited by Bianca Basciano, Franco Gatti and Anna Morbiato. Venezia: Ca'Foscari, vol. 6, pp. 341-60. [CrossRef]

Anderl, Christoph, ed. 2021. Database of Medieval Chinese Texts 中古寫本資料庫. Ghent. New Taipei 新北市: Ghent University; Dharma Drum Institute of Liberal Arts 法鼓文理學院, Available online: https:/ / www.database-of-medieval-chinese-texts.be/ (accessed on 26 October 2021).

Bā, Zhòu 巴宙 (W. Pachow), ed. 1965. Dūnhuáng yùnwén ji 敦煌韻文集. [QFS: 136-47]. Gāoxióng 高雄: Fójiào wénhuà fúwùchù chūbăn 佛敎文化服務處出版.

Baba, Hisayuki 馬場久幸. 2004. Tōgoku Daigakkō hon Kōrai Daizōkyō ni tsuite一Kōrai Daizōkyō no kansū wo chūshin ni 東国大学校 本高麗大蔵経について: 高麗大蔵経の巻数を中心に. Indogaku bukkyōgaku kenkyu 印度學佛教學研究 52: 678-80. [CrossRef]

Bái, Yùlín 白玉林, and Duó Chí 遲鐸. 2004. Gǔ hànyǔ xūcí cídiăn 古漢語虛詞詞典. Běijīng 北京: Zhōnghuá shūjú 中華書局.

Baxter, William H., and Laurent Sagart. 2014. The Baxter-Sagart Reconstruction of Old Chinese (Version 1.1). Available online: http:/ / ocbaxtersagart.lsait.lsa.umich.edu/ (accessed on 1 March 2021).

Beekes, Robert S. P., and Lucien van Beek. 2010. Etymological Dictionary of Greek. Leiden: Brill.

Biāodiăn Zīzhì tōngjiàn xiǎozǔ 標點資治通鑑小組, ed. 1976. Zīzhì tōngjiàn 資治通鑑. Běijīnng 北京: Zhōnghuá shūjú 中華書局.

Bingenheimer, Marcus, and Po-Yung Chang 張伯雍, eds. 2018. Four Early Chan Texts from Dunhuang-A TEI-Based Edition 早期禪宗文獻 四部一以TEI標記重訂敦煌寫卷. vol. 1: Facsimiles and Diplomatic Transcription 摹寫版. Taipei: Shin Wen Feng Print Co. 新文豐出版 股份有限公司. [CrossRef]

Brose, Benjamin. 2015. Patrons and Patriarchs: Chan Monks and Regional Rulers during the Five Dynasties and Ten Kingdoms. Honolulu: University of Hawai'i Press. [CrossRef]

Brough, John. 1962. The Gāndhārī Dharmapada. London: Oxford University Press.

Broughton, Jeffrey L. 2017. Chan Literature. In Oxford Research Encyclopedia of Religion. Oxford: Oxford University Press. [CrossRef]

Buswell, Robert E., Jr. 2004. Sugi's Collation Notes to the Koryŏ Buddhist Canon and Their Significance for Buddhist Textual Criticism. Journal of Korean Studies 9: 129-84. [CrossRef]

Carter, John Ross, and Mahinda Palihawadana, eds. 2000. The Dhammapada. New York: Oxford University Press.

Chén, Yàodōng 陳耀東, and Jìngmǐn Zhōu 周靜敏. 2001. Zǔtáng jí jí qí jíyì 《祖堂集》及其輯佚. Wénxiàn 文獻 1: 91-104.

Chinese Buddhist Electronic Text Association 中華電子佛典協會. 2021. CBETA Online Reader (Xiànshàng Yuèdú 線上閱讀). Available online: https:/ / cbetaonline.dila.edu.tw / (accessed on 1 August 2021).

Clark, Hugh R. 1991. Community, Trade, and Networks: Southern Fujian Province from the Third to the Thirteenth Centuries. Cambridge: Cambridge University Press. 
Clark, Hugh R. 2009. The Southern Kingdoms between the T'ang and the Sung, 907-979. In The Cambridge History of China, vol. 5, Part One: The Sung Dynasty and Its Precursors, 907-1279. Edited by Denis Twitchett and Paul Jakov Smith. Cambridge: Cambridge University Press, pp. 133-205. [CrossRef]

Davis, Richard L. 2004. Historical Records of the Five Dynasties. New York: Columbia University Press.

Demiéville, Paul. 1970. Le Recueil de la Salle des patriarches, 'Tsou-t'ang tsi'. T'oung Pao 56: 262-86. [CrossRef]

Dhammajoti, Kuala Lumpur. 1995. The Chinese Version of Dharmapada. Colombo: Postgraduate Institute of Pali and Buddhist Studies, University of Kelaniya.

Dù, Jiéxiáng 杜潔祥, ed. 1982. Zhōngguó fósì shǐzhì huìkān 中國佛寺史志彙刊. 110 vols. Táiběi 臺北: Míngwén shūjú 明文書局 and Dānqīng túshū gōngsī 丹青圖書公司, vol. 8.

Faure, Bernard. 1997. The Will to Orthodoxy: A Critical Genealogy of Northern Chan Buddhism. Translated by Phyllis Brooks. Stanford: Stanford University Press.

Faure, Bernard. 2003. Chan and Zen Studies: The State of the Field(s). In Chan Buddhism in Ritual Context. Edited by Bernard Faure. London and New York: RoutledgeCurzon, pp. 1-35. [CrossRef]

Faure, Bernard. 2006. Review of Inventing Hui-Neng, the Sixth Patriarch. Hagiography and Biography in Early Ch'an, by John Jorgensen. Études Chinoises 漢學研究 25: 289-99.

Féng, Guódòng 馮國棟. 2014. Jingdé chuándēng lù yánjiūu 《景德傳燈錄》研究. Běijīng 北京: Zhōnghuá shūjú 中華書局.

Féng, Guódòng 馮國棟, ed. 2019. Jǐngdé chuándēng lù 景德傳燈錄. Zhèngzhōu 鄭州: Zhōngzhōu gǔií chūbǎnshè 中州古籍出版社.

Fóguāng dàcídiǎn biānxiū wěiyuánhuì 佛光大辭典編修委員會, ed. 1989. Fóguāng dàcídiǎn 佛光大辭典. Gāoxióng 高雄: Fóguāng chūbănshè 佛光出版社.

Fóguāng dàzàngjīng biānxiū wěiyuánhuì 佛光大藏經編修委員會, ed. 1994. Zǔtáng jí 祖堂集. Gāoxióng 高雄: Fóguāng chūbănshè 佛光 出版社.

Foulk, T. Griffith. 1992. The Ch'an Tsung in Medieval China: School, Lineage, or What. The Pacific World 8: 18-31.

Foulk, T. Griffith, and Robert H. Sharf. 2003. On the Ritual Use of Ch'an Portraiture in Medieval China. In Chan Buddhism in Ritual Context. Edited by Bernard Faure. London and New York: RoutledgeCurzon, pp. 74-150.

Fóxué míngxiāng guīfàn zīliàokù jiànzhì jìhuà 佛學名相規範資料庫建置計畫 (Buddhist Studies Authority Database Project). 2021a Rénmíng guîfàn zīliào kù 人名規範資料庫 (Person Authority Database). Available online: http://authority.dila.edu.tw/person (accessed on 1 August 2021).

Fóxué míngxiāng guīfàn zīliàokù jiànzhì jìhuà 佛學名相規範資料庫建置計畫 (Buddhist Studies Authority Database Project). 2021b. Shíjiān guîfàn zīliào kù 時間規範資料庫 (Time Authority Database). Available online: http:/ / authority.dila.edu.tw/time (accessed on 1 August 2021).

Gove, Philip B., ed. 1984. Webster's New Dictionary of Synonyms: A Dictionary of Discriminated Synonyms with Antonyms and Analogous and Contrasted Words. Springfield: Merriam-Webster Inc.

Gǔdài hànyǔ cídiăn 古代漢語詞典, ed. 2003. Gǔdài hànyǔ cídiăn (dàzì běn) 古代漢語詞典 (大字本). Běijīng 北京: Shāngwù yìnshūguăn 商務印書館.

Hànyǔ dàzìdiǎn biānjí wěiyuánhuì 漢語大字典編輯委員會, ed. 2010. Hànyǔ dàzìdiǎn 漢語大字典, 2nd ed. 9 vols. Chéngdū 成都 and Wǔhàn 武漢: Sìchuān císhū chūbǎnshè 四川辭書出版社; Chóngwén shūjú 崇文書局.

Hirakawa, Akira 平川彰, ed. 1997. A Buddhist Chinese-Sanskrit Dictionary 佛教漢梵大辭典. Tōkyō 東京: Reiyūkai 霊友会.

Hoad, T. F., ed. 1996. The Concise Oxford Dictionary of English Etymology. Oxford: Oxford University Press.

Huang, Yi-hsun 黄繹勳. 2006. Lùn Zǔtíng shìyuàn zhī chéngshū, bănběn yǔ tǐlì: yǐ juàn yī zhī Yúnmén lù wéi zhōngxīn 論《祖庭事苑》 之成書、版本與體例一以卷一之《雲門錄》為中心. Fóxué yánjiū zhōngxīn xuébào 佛學研究中心學報 20: 123-63.

Hucker, Charles O. 1985. A Dictionary of Official Titles in Imperial China. Stanford, CA: Stanford University Press.

Ishii, Shūdō 石井修道. 1985. Senshū Kaigenji shi no Shōkei Shōtō no den ni tsuite 『泉州開元寺志』の招慶省僜の伝について. Indogaku bukkyōgaku kenkyū 印度學佛教學研究 34: 270-77. [CrossRef]

Ishii, Shūdō 石井修道. 1986. Senshū Fukusen Shōkei-in no Jōshū Zenji Shōtō to Sodōshū 泉州福先招慶院の浄修禅師省僜と『祖堂集』. Komazawa daigaku bukkyō gakubu kenkyū kiyō 駒澤大學佛教學部研究紀要 44: 155-97.

Jia, Jinhua. 2006. The Hongzhou School of Chan Buddhism in Eighth-Through Tenth-Century China. Albany: State University of New York Press.

Jiă, Jìnhuá 賈晉華. 2011. Băolín zhuàn zhùzhě jí biānzhuàn mùdì kăoshù 《寶林傳》著者及編撰目的考述. Wénxiàn 文獻 2: 131-39.

Jiāng, Lánshēng 江藍生, and Guăngshùn Cáo 曹廣順, eds. 1997. Táng Wǔdài yǔyán cídiăn 唐五代語言詞典. Shànghăi 上海: Shànghăi jiàoyù chūbănshè 上海教育出版社.

Jiàoyùbù yiť̌zì zìdiăn 教育部異體字字典 (6th ed.). 2017. Guójiā jiàoyù yánjiūyuàn yǔwén jiàoyù jí biānyì yánjiū zhōngxīn 國家教育研究 院語文教育及編譯研究中心 and Guóyǔ tuīxíng wěiyuánhuì 國語推行委員會. Available online: https://dict.variants.moe.edu.tw / (accessed on 1 August 2021).

Jorgensen, John. 2005. Inventing Hui-Neng, the Sixth Patriarch: Hagiography and Biography in Early Ch'an. Leiden: Brill.

Kinugawa, Kenji 衣川賢次. 1998. Sodōshū satsuki 祖堂集札記. Zenbunka kenkyūjo kiyō 禅文化研究所紀要 24: 113-28.

Kinugawa, Kenji 衣川賢次. 2007. Guānyú Zǔtáng jí de jiàolǐ 關於祖堂集的校理. In Zǔtáng jí 祖堂集. Edited by Sūn Chāngwǔ 孫昌武, Kinugawa Kenji 衣川賢次 and Nishiguchi Yoshio 西口芳男. Běijīng 北京: Zhōnghuá shūjú 中華書局, vol. 2, pp. 933-54.

Kinugawa, Kenji 衣川賢次. 2010a. Quánzhōu Qiānfó xīnzhù zhūzǔshì sòng yǔ Zǔtáng jí 《泉州千佛新著諸祖師頌》與《祖堂集》. Translated by Jié Lăng 朗潔. Zhōngzhèng dàxué zhōngwén xuéshù niánkān 中正大學中文學術年刊 15: 1-31.

Kinugawa, Kenji 衣川賢次. 2010b. Sodōshū ibun betsuji kōshō: Sodōshū naka no on'in shiryō『祖堂集』異文別字校證:『祖堂集』中の 音韻資料. Tōyōbunka kenkyūjo kiyō 東洋文化研究所紀要 157: 316-191, (1-126). 
Koga, Hidehiko 古賀英彦, ed. 2003. Kunchū Sodōshū 訓注祖堂集. Kyōto 京都: Hanazono daigaku kokusai zengaku kenkyūjō 花園大學 國際禪學研究所, vol. 8 .

Kokusho Kankōkai 国書刊行会, ed. 1908-1909. Kõrai shi 高麗史. 3 vols. Tōkyō 東京: Kokusho kankōkai 国書刊行会, vol. 1.

Komazawa Daigaku Hensanjo 駒澤大學編纂所, ed. 1985. Zengaku daijiten 禪學大辭典. Tōkyō 東京: Taishūkan shoten 大修館書店.

Kroll, Paul W. 2015. A Student's Dictionary of Classical and Medieval Chinese. Leiden: Brill.

Kurz, Johannes L. 2011. China's Southern Tang Dynasty, 937-976. Abingdon: Routledge.

Lancaster, Lewis R., and Sung-bae Park. 1979. The Korean Buddhist Canon: A Descriptive Catalogue. Berkeley: University of California Press. [CrossRef]

Lǐ, Yùkūn 李玉昆. 1995. Dūnhuáng yíshū Quánzhōu Qiānfó xīnzhù zhūzǔshī sòng yánjiū 敦煌遺書《泉州千佛新著諸祖師頌》研究. Dūnhuángxué jikān 敦煌學輯刊 27: 29-35, 8. [QFS: 33-35; 8].

Lǐ, Fāngmín 李芳民. 2006. Táng Wǔdài fósì jikăo 唐五代佛寺輯考. Běijīng 北京: Shāngwù yìnshūguăn 商務印書館.

Lú, Yùliàng 盧玉亮. 2021. Shànggǔ hànyǔ 'ruò' lèi zhǐshì dàicí láiyuán shì xī 上古漢語‘若'類指示代詞來源試析. Zhōngguó yǔwén 中國 語文 1/400: 56-76.

Luó, Zhúfēng 羅竹風, Hànyǔ dàcídiǎn biānjí wěiyuánhuì 漢語大詞典編輯委員會, and Hànyǔ dàcídiǎn biānzuǎnchù 漢語大詞典編纂 處, eds. 1986-1996. Hànyǔ dàcídiăn 漢語大詞典. 12 vols. Shànghăi 上海: Shànghăi císhū chūbănshè 上海辭書出版社.

MacKinnon, John R., and Karen Phillipps. 2000. Zhōngguó niăolèi yězài shǒucè 中國鳥類野外手冊 (A Field Guide to the Birds of China). Translated by Héfēn Lú 盧和芬. Chángshā 長沙: Húnán jiàoyù chūbǎnshè 湖南教育出版社.

Mazanec, Thomas J. 2017. The Medieval Chinese Gāthā and Its Relationship to Poetry. T'oung Pao 103: 94-154. [CrossRef]

McRae, John R. 1986. The Northern School and the Formation of Early Chán Buddhism. Honolulu: University of Hawai'i Press. [CrossRef]

McRae, John R. 2000. The Antecedents of Encounter Dialogue in Chinese Ch'an Buddhism. In The Kōan: Texts and Contexts in Zen Buddhism. Edited by Steven Heine and Dale S. Wright. New York: Oxford University Press, pp. 46-74.

McRae, John R. 2003. Seeing through Zen: Encounter, Transformation, and Genealogy in Chinese Chan Buddhism. Berkeley: University of California Press. [CrossRef]

Mochizuki, Shinkō 望月信亨, ed. 1932-1936. Mochizuki bukkyō daijiten 望月佛教大辞典. 10 vols. Tōkyō 東京: Sekai seiten kankō kyōkai 世界聖典刊行協會.

Monier-Williams, Monier. 1899. A Sanskrit-English Dictionary Etymologically and Philologically Arranged with Special Reference to Cognate Indo-European Languages. Oxford: Clarendon Press.

Nakamura, Hajime 中村元, ed. 2001. Kōsetsu bukkyōgo daijiten 広説佛教語大辞典. 4 vols. Tōkyō 東京: Tōkyō shoseki 東京書籍.

Norman, Kenneth R. 1997. A Philological Approach to Buddhism: The Bukkyō Dendō Kyōkai Lectures 1994. London: School of Oriental and African Studies.

Ogiwara, Unrai 荻原雲来, Tsuji Naoshirō 辻直四郎, and Suzuki Gakujutsu Zaidan 鈴木学術財団, eds. 1986. Kan'yaku taishō bonwa daijiten 漢訳対照梵和大辞典. Shinsō-ban 新装版. Tōkyō 東京: Kōdansha 講談社.

Péi, Xuéhăi 裴學海. 1996. Gǔshū xūzì jíshì 古書虛字集釋. Shànghăi 上海: Shànghăi shūdiàn 上海書店.

Poceski, Mario. 2007. Ordinary Mind as the Way: The Hongzhou School and the Growth of Chan Buddhism. New York: Oxford University Press. [CrossRef]

Poceski, Mario. 2015. The Records of Mazu and the Making of Classical Chan Literature. New York: Oxford University Press. [CrossRef]

Przyluski, Jean. 1923. La Légende de l'empereur Açoka (Açoka-Avadana) dans les textes indiens et chinois. Paris: Paul Geuthner.

Pulleyblank, Edwin G. 1991. Lexicon of Reconstructed Pronunciation: In Early Middle Chinese, Late Middle Chinese and Early Mandarin. Vancouver: UBC Press.

Robson, James. 2009. Power of Place: The Religious Landscape of the Southern Sacred Peak (Nanyue) in Medieval China. Cambridge: Harvard University Asia Center. [CrossRef]

Robson, James. 2011. Formation and Fabrication in the History and Historiography of Chan Buddhism. Harvard Journal of Asiatic Studies 71: 311-49. [CrossRef]

Róng, Xīnjiāng 榮新江. 2007. Dūnhuángxué shíbā jiǎng 敦煌學十八講. Běijīng 北京: Běijīng dàxué chūbǎnshè 北京大學出版社.

Rong, Xinjiang. 2013. Eighteen Lectures on Dunhuang. Translated by Imre Galambos. Leiden: Brill. [CrossRef]

Schlütter, Morten. 2008. How Zen Became Zen: The Dispute over Enlightenment and the Formation of Chan Buddhism in Song-Dynasty China. Honolulu: University of Hawai'i Press. [CrossRef]

Shiina, Kōyū 椎名宏雄. 1980. Hōrinden itsubun no kenkyū 『宝林伝』逸文の研究. Komazawa daigaku bukkyōgakubu ronshū 駒沢大学仏 教学部論集 11: 234-57.

Shiina, Kōyū 椎名宏雄. 1984. Kōrai-ban zenseki to Sōgen-ban 高麗版禅籍と宋元版. Komazawa daigaku bukkyōgakubu ronshū 駒沢大学仏 教学部論集 15: 228-44.

Shiina, Kōyū 椎名宏雄. 2000. Hōrinden no ihon 『宝林伝』の異本. Indogaku bukkyōgaku kenkyū 印度學佛教學研究 49: 68-72. [CrossRef] Strong, John S. 1989. The Legend of King Aśoka: A Study and Translation of the Aśokāvadāna. Delhi: Motilal Banarsidass.

Sturgeon, Donald, ed. 2021. Chinese Text Project 中國哲學書電子化計劃. Available online: https: / / ctext.org (accessed on 1 April 2021). Sū, Jǐnkūn 蘇錦坤. 2016. Făjù jīng de 'jiàodú' yǔ ‘wùyì' 《法句經》的「校讀」與「誤譯」. Făgǔ fóxué xuébào 法鼓佛學學報 19: 93-158.

Sūn, Chāngwǔ 孫昌武, Kinugawa Kenji 衣川賢次, and Nishiguchi Yoshio 西口芳男, eds. 2007. Zǔtáng jí 祖堂集. 2 vols. Běijīng 北京: Zhōnghuá shūjú 中華書局.

Sungahn, Ven. 性安. 2011. Hǎiyìnsì bāwàn dàzàngjīng 海印寺八萬大藏經. Hànzì yánjiū 漢字研究 5: 69-91.

Suzuki, Tetsuo 鈴木哲雄. 1975. Senshū ni okeru zenshū: Godai-jidai wo chūshin toshite 泉州における禅宗: 五代時代を中心として. Indogaku bukkyōgaku kenkyū 印度學佛教學研究 24: 109-13. [CrossRef]

Tanaka, Ryōshō 田中良昭. 1962. Fu hōzō innen den to Zen no dentō: Tonkō shiryō sūshu wo chūshin toshite 付法藏因縁傳と禪の傳燈: 敦煌資料数種を中心として. Indogaku bukkyōgaku kenkyū 印度學佛教學研究 10: 243-46. [CrossRef] 
Tanaka, Ryōshō 田中良昭. 2002. Shōchūshū no rekishi teki seikaku: Danhō gisoku hon Shōchūshū to Hōrinden hon Shōchūshū 《聖贯集》 の歷史的性格: 壇法儀則本《聖冒集》と寶林傳本《聖冒集》. Komazawa daigaku bukkyōgakubu kenkyū kiyō 駒沢大学仏教学部研究 紀要 60: 31-52.

Tanaka, Ryōshō 田中良昭, and Zhèng Chéng 程正. 2008. Tonkō Zenshū bunken bunrui mokuroku: Shogen, I. Tōshirui 敦煌禪宗文獻分 類目録: 緒言, I. 燈史類. Komazawa daigaku zen kenkyūjo nenpō 駒澤大學禪研究所年報 20: 280-250.

Tián, Qíshí 田其湜, ed. 2004. Liùtǐ shūfă dàzìdiăn 六體書法大字典. 2 vols. Chángshā 長沙: Húnán rénmín chūbănshè 湖南人民出版社.

Universität zu Köln: Institut für Indologie. 2021. Cologne Digital Sanskrit Dictionaries. Available online: https://www.sanskritlexicon.uni-koeln.de/ (accessed on 1 August 2021).

Vaan, Michiel de. 2008. Etymological Dictionary of Latin and the Other Italic Languages. Leiden: Brill.

Van Cutsem, Laurent. 2020a. Chán master Jìngxiū's 淨修禪師 preface to the Zǔtáng jí 祖堂集 (K.1503): A TEI-based edition. Database of Medieval Chinese Texts; Ghent University and Dharma Drum Institute of Liberal Arts 法鼓文理學院. Available online: https: // www.database-of-medieval-chinese-texts.be/ (accessed on 26 October 2021).

Van Cutsem, Laurent. 2020b. The Goryeo 高麗 preface to the Zǔtáng ji 祖堂集 (K.1503): A TEI-based edition. Database of Medieval Chinese Texts; Ghent University and Dharma Drum Institute of Liberal Arts 法鼓文理學院. Available online: https://www. database-of-medieval-chinese-texts.be/ (accessed on 26 October 2021).

Van Cutsem, Laurent. 2020c. The Zǔtáng ji 祖堂集: A Comprehensive .xlsx Table of Its Contents and Structure. Database of Medieval Chinese Texts; Ghent University and Dharma Drum Institute of Liberal Arts 法鼓文理學院. Available online: https://www. database-of-medieval-chinese-texts.be/ (accessed on 26 October 2021).

Van Cutsem, Laurent. 2021. The Quánzhōu Qiānfó xīnzhù zhūzǔshī sòng 泉州千佛新著諸祖師頌 (S.1635): A TEI-based edition. Database of Medieval Chinese Texts; Ghent University and Dharma Drum Institute of Liberal Arts 法鼓文理學院. Available online: https: // www.database-of-medieval-chinese-texts.be/ (accessed on 26 October 2021).

Vermeersch, Sem. 2014. Buddhism in Korean History. In The Wiley Blackwell Companion to East and Inner Asian Buddhism. Edited by Mario Poceski. Oxford: John Wiley \& Sons, Ltd., pp. 63-83. [CrossRef]

Wáng, Ānquán 王安全, and Líng Guō 郭玲, eds. 1997. Hàndà chéngyǔ dàcídiăn 漢大成語大詞典. Jīngbiān běn 精編本. Shànghăi 上海: Hànyǔ dàcídiăn chūbǎnshè 漢語大詞典出版社.

Wáng, Cuilíng 王翠玲. 1999. Sugyōroku no seiritsu『宗鏡録』の成立. Indogaku bukkyōgaku kenkyū 印度學佛教學研究 48: 358-355. [CrossRef]

Wáng, Hăifēn 王海荣, Zhăngcái Zhào 趙長才, Shān Huáng 黃珊, and Kěyǐng Wú 吳可穎, eds. 1999. Gǔhànyǔ xūcí cídiăn 古漢語虛詞詞 典. Běijīnn 北京: Běijīng dàxué chūbănshè 北京大学出版社. First published 1996.

Wáng, Hăigēn 王海根, ed. 2006. Gǔdài hànyǔ tōngjiăzì dàzìdiăn 古代漢語通假字大字典. Fúzhōu 福州: Fújiàn rénmín chūbănshè 福建人 民出版社.

Wáng, Jiànyǐn 王劍引, ed. 2000a. Gǔhànyǔ dàcídiăn 古漢語大詞典. Shànghăi 上海: Shànghǎi císhū chūbănshè 上海辭書出版社.

Wáng, Lì 王力, ed. 2000b. Wáng Lì gǔhànyǔ zìdiǎn 王力古漢語字典. Běijīng 北京: Zhōnghuá shūjú 中華書局.

Wáng, Róngguó 王榮國. 1997. Fújiàn fójiào sȟ̃ 福建佛教史. Xiàmén 廈門: Xiàmén dàxué chūbănshè 廈門大學出版社.

Wáng, Shūmín 王叔岷. 2007. Gǔji xūzì guăngyì 古籍虛字廣義. Běijīng 北京: Zhōnghuá shūjú 中華書局.

Wáng, Zhèngbái 王政白, ed. 1986. Gǔhànyǔ xūcí cídiǎn 古漢語虛詞詞典. Héféi 合肥: Huángshān shūshè 黃山書社.

Welter, Albert. 2006. Monks, Rulers, and Literati: The Political Ascendancy of Chan Buddhism. New York: Oxford University Press. [CrossRef]

Welter, Albert. 2008. The Linji Lu and the Creation of Chan Orthodoxy: The Development of Chan's Records of Sayings Literature. New York: Oxford University Press.

Wittern, Christian. 1998. Das Yulu des Chan-Buddhismus: Die Entwicklung vom 8.-11. Jahrhundert am Beispiel des 28. Kapitels des Jingde Chuandenglu (1004). Bern: Peter Lang.

Wú, Chéngyuān 吳澄淵, ed. 2001. Xìnbiān Zhōngguó shūfă dàzìdiăn 新編中國書法大字典. Běijīng 北京: Shìjiè túshū chūbăn gōngsī 世界 圖書出版公司.

Wu, Jiang. 2015. The Chinese Buddhist Canon Through the Ages: Essential Categories and Critical Issues in the Study of a Textual Tradition. In Spreading Buddha's Word in East Asia: The Formation and Transformation of the Chinese Buddhist Canon. New York: Columbia University Press, pp. 15-45. [CrossRef]

Wu, Jiang, and Ron Dziwenka. 2015. Better Than the Original: The Creation of Goryeo Canon and the Formation of Giyang Bulgyo. In Spreading Buddha's Word in East Asia Section: Spreading Buddha's Word in East Asia. New York: Columbia University Press, pp. 249-83. [CrossRef]

Wú, Fúxiáng 吳福祥, and Zhīchuān Gù 顧之川, eds. 1996. Zǔtáng jí 祖堂集. Chángshā 長沙: Yuèlù shūshè 岳麓書社.

Wú, Wénliáng 吳文良, and Yòuxióng Wú 吳幼雄. 2005. Quánzhōu zōngjiào shíkè 泉州宗教石刻. Zēngdìng běn 增訂本. Běijīng 北京: Kēxué chūbǎnshè 科學出版社.

Xiàng, Dézhēn 向德珍. 2005. Quánzhōu Qiānfó xīnzhù zhūzǔshī sòng yǔ Zǔtáng jỉ ‘Jìngxiū Chánshī zàn' jiàolù 《泉州千佛新著諸祖師頌》 與《祖堂集》“淨修禪師讚”校録. Jiǔzhōu xuélin 九州學林 3: 160-89.

Xú, Hán 徐寒, ed. 2009. Shūfă dàzihǎi 書法大字海. Xiūdìng bǎn 修訂版. 2 vols. Běijīng 北京: Shāngwù yìnshūguăn guójì yǒuxiàn gōngsī 商務印書館國際有限公司.

Yampolsky, Philip B. 2012. The Platform Sutra of the Sixth Patriarch: The Text of the Tun-Huang Manuscript. New York: Columbia University Press.

Yanagida, Seizan 柳田聖山. 1953. Sodōshū no shiryō kachi (1): Tōki zenseki no hihanteki sochi ni kansuru hitotsu no kokoromi 『祖 堂集』の資料價值 (一): 唐期禪籍の批判的措置に關する一つの試み. Zengaku kenkyū 禪學研究 44: 31-80, Originally published under the name Yokoi Seizan 横井聖山. 
Yanagida, Seizan 柳田聖山. 1964. Sodōshū no honbun kenkyū (1) 祖堂集の本文研究 (一). Zengaku kenkyū 禪學研究 54: 11-87. Yanagida, Seizan 柳田聖山. 1976. Zenseki kaidai 禅籍解題. In Zenke Goroku 禅家語録. Edited by Nishitani Keiji 西谷啓治 and Yanagida Seizan 柳田聖山. Tōkyō 東京: Chikuma shobō 筑摩書房, vol. 2, pp. 445-514.

Yanagida, Seizan 柳田聖山. 1980-1984. Sodōshū sakuin 祖堂集索引. 3 vols. Kyōto 京都: Kyōto daigaku jinbun kagaku kenkyūjo 京都大 学人文科学研究所.

Yanagida, Seizan 柳田聖山. 1983. The Recorded Sayings Texts of Chinese Ch'an Buddhism. In Early Ch'an in China and Tibet. Edited by Whalen Lai and Lewis R. Lancaster. Translated by John R. McRae. Berkeley: University of California Press, pp. 185-205.

Yanagida, Seizan 柳田聖山. 1985. Goroku no rekishi: Zenbunken no seiritsu shiteki kenkyū 語録の歴史: 禪文獻の成立史的研究. Tōhō gakuhō 東方學報 57: 211-663. [CrossRef]

Yáng, Zēngwén 楊曾文. 2001. Zhēnguì de zăoqí chánzōng shǐshū Zǔtáng jí: dàixù 珍貴的早期禪宗史書《祖堂集》: 代序. In Zǔtáng jí 祖堂集. Edited by Huá Zhāng 張華. Zhèngzhōu 鄭州: Zhōngzhōu gǔjí chūbǎnshè 中州古籍出版社, pp. 1-20.

Yáng, Zēngwén 楊曾文. 2006a. Sòng Yuán Chánzōng shř 宋元禪宗史. Běijīng 北京: Zhōngguó shèhuì kēxué chūbănshè 中國社會科學出 版社.

Yáng, Zēngwén 楊曾文. 2006b. Táng Wǔdài Chánzōng shř 唐五代禪宗史. Běijīng 北京: Zhōngguó shèhuì kēxué chūbănshè 中國社會科學 出版社. First published 1999.

Young, Stuart H. 2015. Conceiving the Indian Buddhist Patriarchs in China. Honolulu: University of Hawai'i Press. [CrossRef]

Zhān, Xùzuǒ 詹緒左. 2018. Chánjí cíyǔ yánjiū: yǐ 'Zǔtáng jí wéi zhǔyào kăochá duìxiàng 禪籍詞語研究: 以'祖堂集'為主要考察對象. Běijīng 北京: Kēxué chūbănshè 科学出版社.

Zhāng, Huá 張華, ed. 2001. Zǔtáng jí 祖堂集. Zhèngzhōu 鄭州: Zhōngzhōu gǔjí chūbǎnshè 中州古籍出版社.

Zhāng, Měilán 張美蘭. 2003. 'Zǔtáng jí' yǔfă yánjiū 《祖堂集》語法研究. Běijīng 北京: Shāngwù yìnshūguǎn 商務印書館.

Zhāng, Měilán 張美蘭, ed. 2009. Zǔtáng jí jiàozhù 祖堂集校注. Běijīng 北京: Shāngwù yìnshūguăn 商務印書館.

Zhèng, Zhènmăn 鄭振滿, and Héshēng Dīng 丁荷生 (Kenneth Dean), eds. 2003. Fújiàn zōngjiào bēimíng huìbiān: Quánzhōu fǔ fēncè 福建 宗教碑銘彙編: 泉州府分冊. 3 vols. Fúzhōu 福州: Fújiàn rénmín chūbǎnshè 福建人民出版社, vol. 1.

Zhèng, Tiāntǐng 鄭天挺, Zé Wú 吳澤, Zhìjiǔ Yáng 楊志玖, and Qíxiāng Tán 譚其驤, eds. 1996. Zhōngguó lìshǐ dàcídiăn: lìshǐ dìľ̌ 中國歷史 大辭典: 歷史地理. Shànghăi 上海: Shànghăi císhū chūbănshè 上海辭書出版社.

Zhōngguó shèhuì kēxuéyuàn yǔyán yánjiūsuǒ 中國社會科學院語言研究所, and Gǔdài hànyǔ yánjiūshì 古代漢語研究室, eds. 1999. Gǔdài hànyǔ xūcí cídiăn 古代漢語虛詞詞典. Běijīng 北京: Shāngwù yìnshūguăn 商務印書館. 